\title{
LANDBIRD RESPONSE TO FINE-SCALE HABITAT CHARACTERISTICS WITHIN RIPARIAN FORESTS OF THE CENTRAL CALIFORNIA COAST
}

\author{
A Thesis \\ Presented to \\ The Faculty of California Polytechnic State University, \\ San Luis Obispo
}

\author{
In Partial Fulfillment \\ Of the Requirements for the Degree \\ Master of Science in Biological Sciences \\ By
}

Ronald E. Melcer Jr.

March 2012 
(C) 2012

Ronald E. Melcer Jr.

ALL RIGHTS RESERVED 


\section{COMMITTEE MEMBERSHIP}

TITLE: $\quad$ Landbird Response to Fine-scale Habitat

Characteristics within Riparian Forests of the Central California Coast

AUTHOR: $\quad$ Ronald E. Melcer Jr.

DATE SUBMITTED: $\quad$ March 232012

COMMITTEE CHAIR: Francis Villablanca, Ph.D.

COMMITTEE MEMBER: John Perrine, Ph.D.

COMMITTEE MEMBER: Scott Steinmaus, Ph.D. 


\begin{abstract}
Landbird Response to Fine-scale Habitat Characteristics within Riparian Forests

of the Central California Coast
\end{abstract}

Ronald E. Melcer Jr.

Riparian corridors in California are known to be an important but reduced and degraded resource for landbirds. In spite of previous research, the habitat characteristics that correlate with high landbird abundance remain poorly understood. In particular, the scale at which predictive models are useful (fine scale, watershed, sub-region or region) is ill defined. Herein, point count-based abundance indices for 8 riparian associated/obligate species with uniform and high detection probabilities are correlated with biotic and abiotic habitat variables: a sums of squares procedure is used to select the top 5 predictive variables for each species, best fit linear models are selected in an information theoretic framework, and the relative importance of individual variables assessed. These analyses identified site and vegetation characteristics that could serve as targets for restoration and conservation efforts within this coastal central California region. The specific characteristics vary somewhat across the 8 species I surveyed. In addition, the characteristics that I have found important as predictors are distinct from analyses that others have conducted. Therefore, just as we should probably accept regional variation in the composition of riparian avifaunas, we should also probably expect regional variation in the relationship between habitat variables and avian abundance. It appears that important habitat characteristics vary at the fine, watershed, sub-region and regional scales thus reducing the generality of all of the currently available models.

Keywords: avian, habitat association, Akaike Information Criteria, 


\section{ACKNOWLEDGMENTS}

This thesis would not have been possible without the support and encouragement, assistance, and guidance of many colleagues, family, and friends. First and foremost, I would like to thank my supervisor, Francis Villablanca, Professor within the Biological Sciences Department at Cal Poly. I am especially grateful for the time, space, critical thought, as well as the energy he has dedicated toward this project and my education during my time at Cal Poly. I also greatly appreciate his un-ending patience with the intra-and interannual variation of my presence on campus, and the autonomy that he has afforded me during my time in his lab. He has challenged me over the past several years to think critically and scientifically about this study, and has greatly influenced my approach to the project and to science as a whole. He has been an invaluable mentor, and I look forward to continuing to learn from him and work on future studies.

I would like to thank my parents, who have been a constant source of support and encouragement in the pursuit of my education goals, in life in general, and the study of birds. The countless discussions of field methods, the site visits, the hard questions, and the help with data management over the years have all been fundamentally important in arriving at this thesis document.

Ben Carter, Danika Tsao, Erica Lindgren, Mary Chambers, Mike Tyner, Michaela Koenig, and Neil Clipperton were all fundamental in setting up the field components of the study, and made collecting information on plants and birds in San Luis Obispo County a reality.

I would like to thank Rachel Gardiner for the helping with the motivation in applying and attending graduate school. Also, for the countless hours of discussion on many statistical approaches ultimately explored, and especially for her assistance with writing code and running R, Survive, and ArcMap.

I would like to thank my other committee members, John Perrine and Scott Steinmaus for their helpful comments on multiple thesis drafts.

Also, Maggie Smith, Brad Schram, Tom Edell, Jaime Chavez, Linda Tanner, Joyce Corey, David Keeling, Alan Schmierer and John Sterling all provided wonderful pictures of birds for presentations at conferences and meetings.

Annie Gillespie, Anna Halligan, Jodi Isaacs, Andrea Jones, Darlene Woodbury, Michael Moore, Matt Ritter, Neil Havlik, and others provided support, encouragement, and access to public and private lands where fieldwork was conducted. 


\section{TABLE OF CONTENTS}

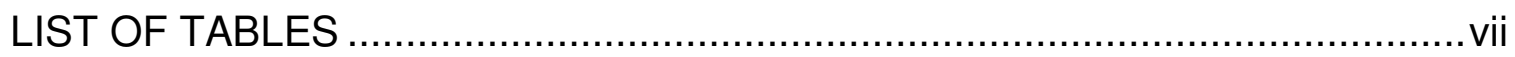

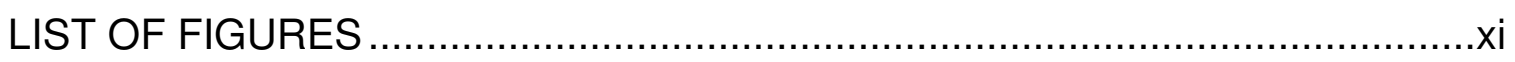

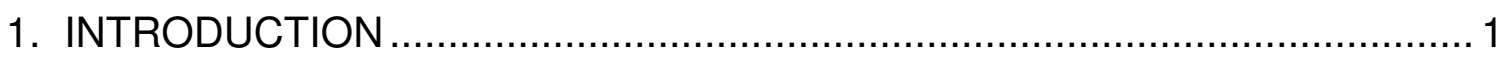

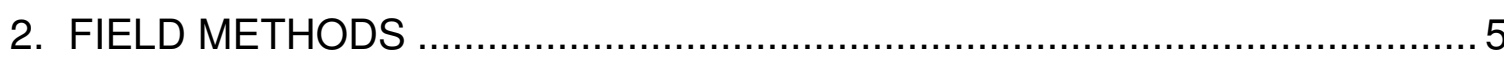

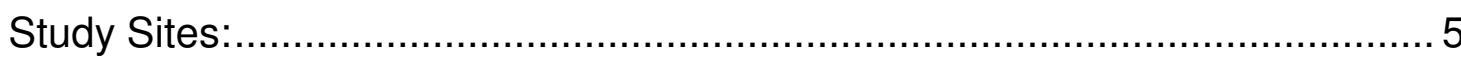

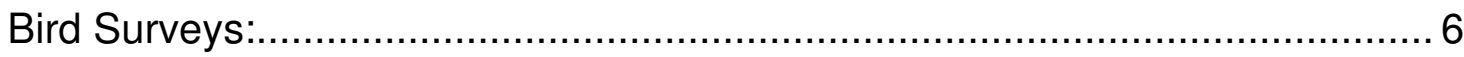

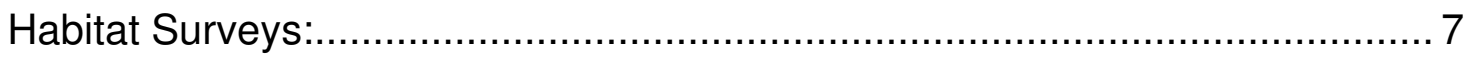

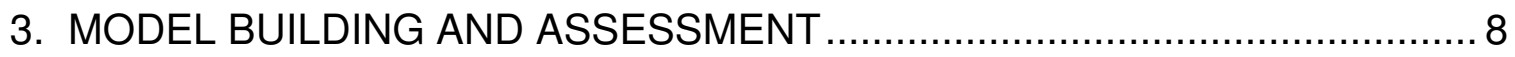

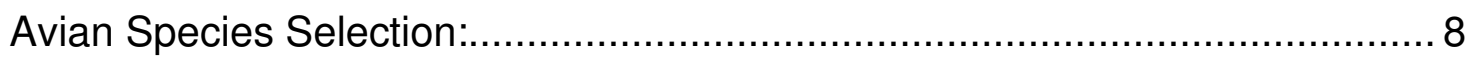

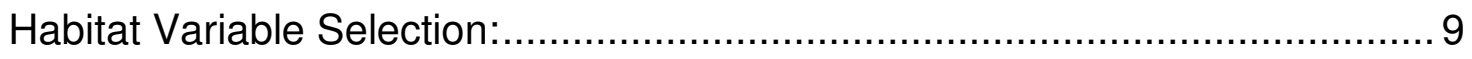

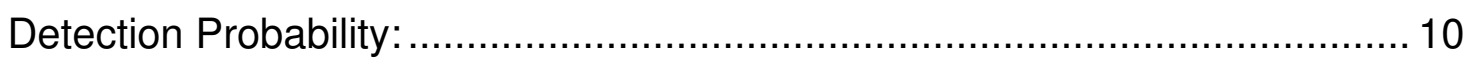

Treatment of the Response Variables:........................................................ 12

Statistical Analysis Including Model Selection:............................................. 12

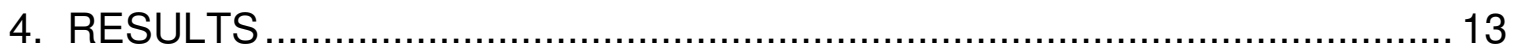

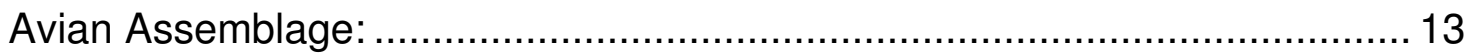

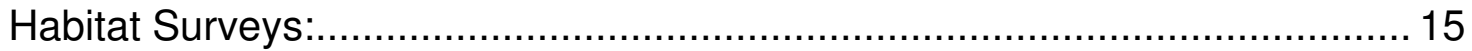

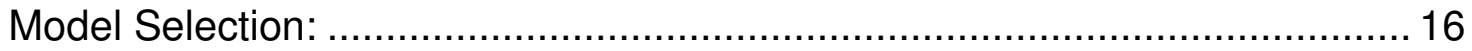

Black-headed Grosbeak ................................................................ 16

Orange-crowned Warbler ............................................................... 18

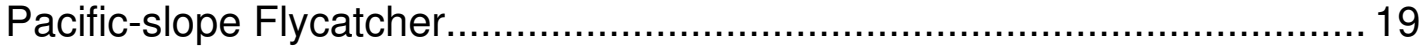

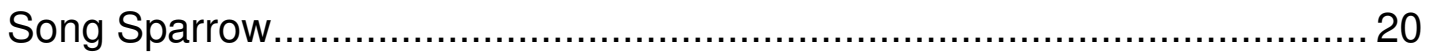

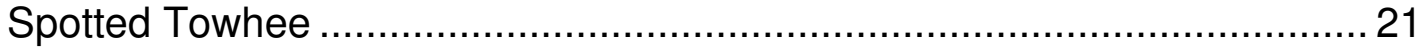

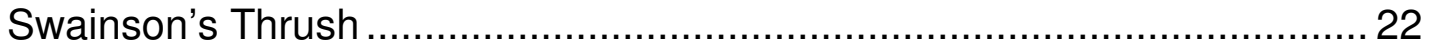

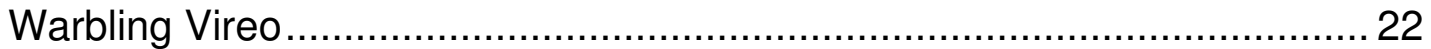

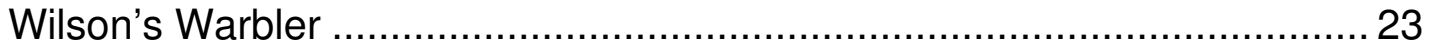

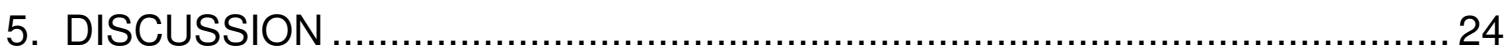

Implications to Land Management and Restoration Efforts:.......................... 24

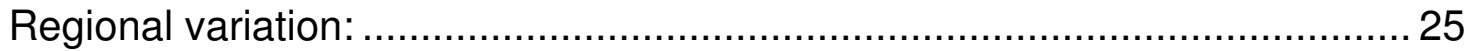

Conservation Implications and Future Research Needs: ............................ 27

Implications and limitations of analytical approach: .................................... 28

Implications and Limitations of Habitat Analyses: ........................................ 29

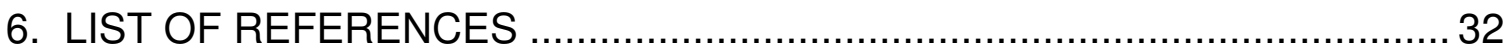

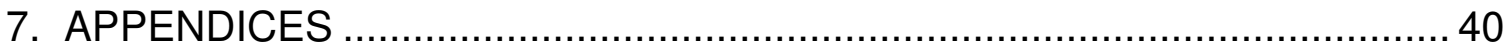


Appendix A. Geographic coordinates and maps for avian and vegetation sampling plots.

Appendix B. Tests of assumptions for linear models.

Appendix C. Summary of bird and plant species detected during the study duration 62

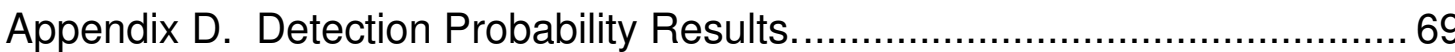

Appendix E. AIC Summary ……........................................................ 71 


\section{LIST OF TABLES}

Table

Page

1. Common names of species analyzed, scientific names, known riparian associated species, and RHJV focal species (BLM 1998, RHJV 2004), and total detections at all point counts stations $(n=96)$.

2. Subset of predictor variables evaluated for analysis, their unit of measure, inclusion in previous studies of riparian bird habitat associations, and disposition in final models of this study.... 10

3. Summary of three models of the 63 tested for Black-headed Grosbeak with AICc values <2.0, including model terms, number of parameters (K), log likelihood value, AIC and AICc scores, change in AICc score ( $\mathrm{AICC}$ ) between models, and AICc weight $(\mathrm{Wi})$....

4. Summary of variables used (based on sums of squares selection) which were regarded as possible predictor variables. For each of the variables which were selected in a model, the direction of their regression line slope indicates the nature of the correlation between each bird species and habitat variables....

5. Table of the summed Wi values (derived from 63 models tested for each species) for each of the variables included in the final model sets.

6. Summary of six models of the 63 tested for Orange-crowned Warbler with AICc values <2.0, including model terms, number of parameters $(\mathrm{K})$, log likelihood value, AIC and AICc scores, change in AICc score ( $\mathrm{AICc}$ ) between models, and AICc weight (Wi)....

7. Summary of five models of the 63 tested for Pacific-slope Flycatcher with AICc values $<2.0$, including model terms, number of parameters (K), log likelihood value, AIC and AICc scores, change in AICc score ( $\mathrm{AIC}$ ) between models, and AICc weight (Wi)

8. Summary of eleven models of the 63 tested for Song Sparrow, with AICc values <2.0, including model terms, number of parameters (K), log likelihood value, AIC and AICc scores, change in AICc score ( $\mathrm{AICc}$ ) between models, and AICc weight (Wi).

9. Summary of two models of the 63 tested for Spotted Towhee, with 
AICc values $<2.0$, including model terms, number of parameters $(\mathrm{K})$, log likelihood value, AIC and AICc scores, change in AICc score ( $\mathrm{AICc}$ ) between models, and AICc weight (Wi). .22

10. Summary of six models of those the 63 for Swainson's Thrush, with AICc values <2.0, including model terms, number of parameters (K), log likelihood value, AIC and AICc scores, change in AICc score ( $\mathrm{AICc}$ ) between models, and AICc weight (Wi). 22

11. Summary of six models of the 63 tested for Warbling Vireo with AICc values <2.0, including model terms, number of parameters $(\mathrm{K})$, log likelihood value, AIC and AICc scores, change in AICc score ( $\mathrm{AICC}$ ) between models, and AICc weight (Wi).... 23

12. Summary of six models of the 63 tested for Wilson's Warbler with AICc values $<2.0$, including model terms, number of parameters (K), log likelihood value, AIC and AICc scores, change in AICc score ( AICc) between models, and AICc weight (Wi)

A1. Summary of site, site acronym, point count name, and GPS coordinates for all sampling plots. Data were recorded in UTM, Zone 10 S,WGS84.

B1. Pearson's Correlation Coefficents and corresponding p-values for habitat variables. The null hypothesis for this test is that there is no linear correlation between the habitat variables being evaluated ( $x$ vs. $y$ ). Correlations were assessed at critical value of 0.60 , and pairwise comparison's that exceeded $r=0.60$ are shown in bold.

B2. Summary of Levene's test statistics (W) and p-values.D1.

Detection probability estimates, standard error (SE) and 95\% confidence intervals for all bird species analyzed.

C1. The common name, scientific name, and summary detections of bird species at sampling plots $(n=96)$ throughout the study period.

C2. The family, scientific name, common name and origin status of plant species identified during relevé surveys within $50 \mathrm{~m}$ radius $(0.785 \mathrm{ha})$ sampling plots $(\mathrm{n}=96)$ within the canopy height strata $(>5.0 \mathrm{~m})$.

C3. The family, scientific name, common name and origin status of plant species identified during relevé surveys within $50 \mathrm{~m}$ radius ( $0.785 \mathrm{ha})$ sampling plots $(\mathrm{n}=96)$ within the shrub height strata 
C4. The family, scientific name, common name and origin status of plant species identified during relevé surveys within $50 \mathrm{~m}$ radius ( $0.785 \mathrm{ha})$ sampling plots $(\mathrm{n}=96)$ within the herbaceous height strata $(>0.0-1.0 \mathrm{~m})$.

D1. Detection probability estimates, with standard error (SE) and $95 \%$ confidence intervals for all bird species analyzed.

D2. Detection probability estimates by year, standard error (SE) and $95 \%$ confidence intervals for all bird species analyzed.

E1. Summary of all 63 models tested for Black-headed Grosbeak, including model terms, number of parameters $(\mathrm{K})$, log likelihood value, $\mathrm{AIC}$ and $\mathrm{AICc}$ scores, change in AICc score ( AICc) between models, likelihood value (L) and AICc weight (Wi)

E2. Summary of all 63 models tested for Orange-crowned Warbler, including model terms, number of parameters $(K)$, log likelihood value, $\mathrm{AIC}$ and $\mathrm{AICc}$ scores, change in AICc score ( AICc) between models, likelihood value $(\mathrm{L})$ and $\mathrm{AICc}$ weight $(\mathrm{Wi})$

E3. Summary of all 63 models tested for Pacific-slope Flycatcher, including model terms, number of parameters $(\mathrm{K})$, log likelihood value, AIC and AICc scores, change in AICc score ( AICc) between models, likelihood value (L) and AICc weight (Wi)

E4. Summary of all 63 models tested for Song Sparrow, including model terms, number of parameters (K), log likelihood value, QAIC and QAICc scores, change in QAICc score ( QAICc) between models, likelihood value (L) and AICc weight (Wi)....

E5. Summary of all 63 models tested for Spotted Towhee, including model terms, number of parameters (K), log likelihood value, AIC and AICc scores, change in AICc score ( AICc) between models, likelihood value (L) and AICc weight (Wi)

E6. Summary of all 63 models tested for Swainson's Thrush, including model terms, number of parameters (K), log likelihood value, AIC and AICc scores, change in AICc score ( AICc) between models, likelihood value $(\mathrm{L})$ and $\mathrm{AICc}$ weight $(\mathrm{Wi})$

E7. Summary of all 63 models tested for Warbling Vireo, including model terms, number of parameters (K), log likelihood value, AIC 
and AICc scores, change in AICc score ( $\mathrm{AICc}$ ) between models, likelihood value (L) and AICc weight (Wi)

E8. Summary of all 63 models tested for Wilson's Warbler, including model terms, number of parameters $(\mathrm{K})$, log likelihood value, AIC and AICc scores, change in AICc score ( AICc) between models, likelihood value (L) and AICc weight (Wi) 


\section{LIST OF FIGURES}

Figure

Page

1. Study region and eight riparian study sites with acronyms. Survey Point locations (UTM; datum WGS84) are summarized in Appendix 1.

A1. Map of the Arroyo Grande field site including point count locations and vegetation sampling plots over CA Department of Fish and Game 2009 summer aerial imagery in natural color.

A2. Map of the Cerro Alto field site including point count locations and vegetation sampling plots over CA Department of Fish and Game 2009 summer aerial imagery in natural color

A3. Map of the Coon Creek field site including point count locations and vegetation sampling plots over CA Department of Fish and Game 2009 summer aerial imagery in natural color.

A4. Map of the Pismo Creek field site including point count locations and vegetation sampling plots over CA Department of Fish and Game 2009 summer aerial imagery in natural color. ...

A5. Map of the Reservoir Canyon field site including point count locations and vegetation sampling plots over CA Department of Fish and Game 2009 summer aerial imagery in natural color.

A6. Map of the Santa Rita field site including point count locations and vegetation sampling plots over CA Department of Fish and Game 2009 summer aerial imagery in natural color.

A7. Map of the western segment of the Santa Rosa field site including point count locations and vegetation sampling plots over CA Department of Fish and Game 2009 summer aerial imagery in natural color

A8. Map of the eastern segment of the Santa Rosa field site including point count locations and vegetation sampling plots over CA Department of Fish and Game 2009 summer aerial imagery in natural color.

A9. Map of the San Luis Obispo Creek field site including point count locations and vegetation sampling plots over CA Department of Fish and Game 2009 summer aerial imagery in natural color. 
B1. Scatterplot of \% Cover Oak vs. Elevation, exhibiting linear correlation above the critical value of $r=0.60$.

B2. Scatterplot of \% Cover Bay vs. Elevation, exhibiting linear correlation above the critical value of $r=0.60$.

B3. Normality plot of residuals and summary statistics for the Ryan Joiner test of normality for the global model of Orange-crowned Warbler.

B4. Normality plot of residuals and summary statistics for the Ryan Joiner test of normality for the global model of Swainson's Thrush .52

B5. Normality plot of residuals and summary statistics for the Ryan Joiner test of normality for the global model of Song Sparrow. 53

B6. Normality plot of residuals and summary statistics for the Ryan Joiner test of normality for the global model of Warbling Vireo

B7. Normality plot of residuals and summary statistics for the Ryan Joiner test of normality for the global model of Wilson's Warbler.

B8. Normality plot of residuals and summary statistics for the Ryan Joiner test of normality for the global model of Black-headed Grosbeak.

B9. Normality plot of residuals and summary statistics for the Ryan Joiner test of normality for the global model of Spotted Towhee.

B10. Normality plot of residuals and summary statistics for the Ryan Joiner test of normality for the global model of Pacific-slope Flycatcher.

B11. Scatter Plots of the residual values vs. the fitted values for the global model of Orange-crowned Warbler

B12. Scatter Plots of the residual values vs. the fitted values for the global model of Song Sparrow.

B13. Scatter Plots of the residual values vs. the fitted values for the global model of Warbling Vireo

B14. Scatter Plots of the residual values vs. the fitted values for the global model of Wilson's Warbler.

B15. Scatter Plots of the residual values vs. the fitted values for the 
global model of Black-headed Grosbeak.

B16. Scatter Plots of the residual values vs. the fitted values for the global model of Spotted Towhee........................................................58

B17. Scatter Plots of the residual values vs. the fitted values for the global model of Pacific Slope Flycatcher.

B18. Scatter Plots of the residual values vs. the fitted values for the global model of Swainson's Thrush. 


\section{INTRODUCTION}

In the semi-arid western United States, riparian vegetation supports the most species-rich and abundant communities of birds, and provides critically important habitat for many other wildlife taxa (Katibah 1984, Knopf et al. 1988, Dobkin 1994, Faber 2003). Riparian ecosystems within California maintain populations of Neotropical and Neotemperate breeding birds, as well as migrant and winter resident species (Cogswell 1962, Gaines 1977, Ralph 1998, Humple and Geupel 2002, Flannery et al. 2004, Carlisle et al. 2004).

These same riparian ecosystems throughout the west have suffered substantial losses in distribution and quality due to urban and water resource development, agriculture, and non-native species. Riparian vegetation has been degraded and reduced, currently remaining in only $2-5 \%$ of the historical range (Katibah 1984, Dawdy 1989, Kondolf et al. 1996). This loss of distribution and quality of riverine-associated vegetation has been implicated as one of the most important drivers in the decline of riparian-associated birds (DeSante and George 1994). Recovery and conservation of remaining riparian-dependent bird populations depend significantly on landscape-scale restoration of the distribution and quality of these vegetation communities (Miller 1951, Gaines 1974, Manley and Davidson 1993, Rich 1998, Askins 2002, Donovan et al. 2002). With that said, the landscape-level restoration of river floodplains and riparian vegetation communities has become a conservation priority on the California landscape for birds and other taxa (Jeffres et al. 2008). An example of this elevated prioritization is the Riparian Habitat Joint Venture (RHJV), a collaborative of 
State, federal and non-governmental agencies which has developed a body of technical information with which to strategically implement conservation and restoration of landbird habitats throughout California (RHJV 2004). A major research effort of the RHJV has been to identify the characteristics of riparian habitats needed to maintain healthy species populations. From an avian conservation perspective, understanding these characteristics at multiple spatial scales is a crucial component of science-based restoration and management (Saab 1999, Strong and Bock 1990). More recently, studies have shown that bird species' response to fine scale habitat features varies between landscape regions (Nur et al. 2008, Heath and Ballard 2003). This variation between regions requires land managers and restoration practitioners not only to understand the response at various spatial scales, but also to consider the regional response of bird species to fine scale habitat associations.

Few published studies have addressed landbird trends, demography, or response to habitat characteristics of central California coast riparian vegetation communities. Over the past 20 years, data collection efforts have occurred on California National Guard Camp Roberts, U.S. Army Fort Hunter Liggett, and Vandenberg U.S. Air Force Base (J. Griffiths 2008, N. Seavy 2010, pers. comm.). However, peer-reviewed findings are lacking from these efforts. The current understanding of bird distribution and habitat associations within the central California coast is coarse, and based on the initial works of documentation of birds collected between Monterey and San Simeon by Hubert (1906) and Grinnell and Miller (1944), and the un-published graduate work of Marantz (1988) 
describing the birds of San Luis Obispo and their distribution throughout the county.

Most of the current research targeting riparian-associated landbirds in California has taken place along the major river systems in the Central Valley (Nur and Geupel 2008, Seavy et. al. 2009), and within the Sierra Nevada and eastern Sierra Nevada riparian vegetation communities (Heath and Ballard 2003). These studies were conducted in highly managed watersheds with significantly altered or reduced vegetation communities, resulting from water resource development, agricultural practices, and flood management activities. Studies of riparian landbird communities in coastal California are also based on systems with degraded and altered vegetation communities. In the more arid southern coastal region, Oneil and Rotenberry (2009) incorporated fine scale habitat features in their analysis of the response of multiple species of birds to urbanization. Strusis-Timmer (2009) investigated the response of a single riparian-associated species, Yellow Warbler (Setophaga petechia), on a degraded and altered watershed in north-western Monterey County, to fine scale habitat characteristics such as percent cover and species composition of vegetation.

While the vegetation communities within larger watersheds of the San Luis Obispo and southern Monterey Counties (Salinas River, Santa Maria Valley) have been heavily disturbed or eliminated through agricultural and water development activities, many of the smaller coastal creeks, support structurally diverse native vegetation communities (Melcer pers. obs.). The high quality 
habitats that these watersheds provide present a unique opportunity for investigating the relationships of the region's diverse riparian landbird community in habitats that maintain a high level of native diversity and function.

During the spring of 2006, I initiated a study investigating the breeding bird response to habitat features within these relatively healthy, intact riparian vegetation communities of central coast California. This study did not manipulate variables and assess avian responses. Instead, the study was observational and evaluated independent variables as predictors of avian abundance and distribution. Specific objectives of this study were (1) to collect species-level information on bird abundance, (2) to collect information on habitat structure and the plant community, (3) to develop and rank species-specific correlative models of bird response to region-specific fine scale habitat characteristics, and (4) to identify and assess the relative importance of predictor variables resulting from the models. I utilized standard methods in achieving these objectives in order to produce results that were comparable to similar studies conducted in riparian communities such as Heath and Ballard's work in the eastern Sierra Nevada (Heath and Ballard 2003), Gardali and others work along the Sacramento River (Gardali et al. 2006), and Nur and others investigations throughout the Central Valley of California (Nur et al. 2008).

Here I present an analysis on 8 species of birds that commonly nest in riparian vegetation within the central California coast. A set of candidate models was developed and evaluated for each species. Habitat variables from these models were assessed and ranked according to relative importance. 


\section{FIELD METHODS}

Study Sites: I conducted surveys at 8 field sites along $70 \mathrm{~km}$ of the central California coast $\left(35.38^{\circ} \mathrm{N}, 120.86^{\circ} \mathrm{W}\right)$ between Cambria and Pismo Beach (Figure 1). Watersheds were selected based on the presence of riparian vegetation and availability of access. The downstream survey point at each site was selected based on the presence of forest or woodland physiognomy and riparian-associated tree and shrub species. Subsequent upstream points were placed at 200 m intervals. GPS locations (recorded in UTM; datum WGS 84) for all survey points and site maps are provided in Appendix A, Table A1 and Figures A1-A9.

The western coast range is characterized by coastal scrub, maritime chaparral, and oak woodlands, with dense montane riparian vegetation adjacent to creeks (CWC 2002). Dominant tree species at study sites included red willow (Salix laevigata), arroyo willow (Salix lasiolepus), sandbar willow (Salix exigua), white alder (Alnus rhombifolia), California bay (Umbellularia californica), red-stem dogwood (Cornus sericea), California sycamore (Plantanus racemosa), and black cottonwood (Populus balsamifera). Common shrub species included creeping blackberry (Rubus ursinus), poison oak (Toxicodendron diversilobum), and coyote brush (Baccharis pilularis). 


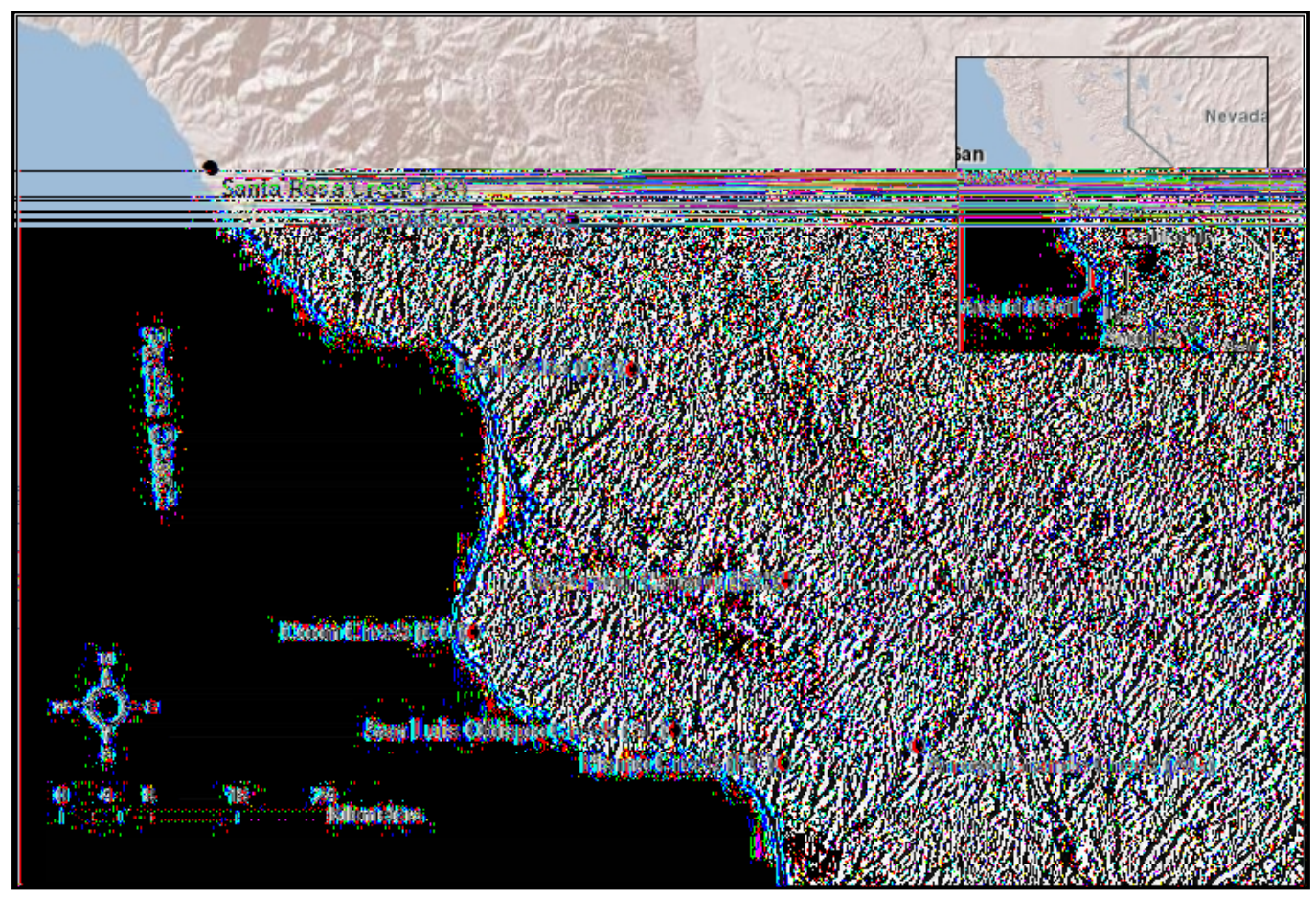

FIGURE 1. Study region and eight riparian study sites with acronyms. Survey point locations are summarized in Appendix A, Table A1.

Bird Surveys: I conducted variable distance point count surveys $(n=96)$ once annually during the breeding season from May through early June for the four years from 2006-2009, using methods described in Ralph et al. $(1993,1995)$.

During each 5 minute sampling event, I recorded the species, number, and distance of all birds detected. I divided the 5 minute sampling period into two time intervals ( $3 \mathrm{~min}$, and $2 \mathrm{~min}$ ) in order to make available the ability to compare results to the Breeding Bird Survey, which uses 3 minute time intervals (Sauer et al. 2011). Birds that were recorded in the first 3 minute time interval were not rerecorded in the second time interval. All surveys were initiated 10 minutes after sunrise and completed within 4 hours. Surveys were not conducted under windy or rainy conditions. 
Habitat Surveys: I recorded habitat characteristics during April of 2009 using 50 $\mathrm{m}$ radius ( $0.785 \mathrm{ha})$ sampling plots located at each point count location. The habitat characterization was done using a relevé approach at each sampling plot (Ralph et al. 1993). I recorded a suite of 13 abiotic, 9 structural, and 6 specieslevel metrics in each plot. Abiotic variables were watershed, site, plot, elevation, slope, aspect, landform, riparian vegetation corridor width, topography, soil moisture, presence of standing water, presence and character of running water. Structural variables recorded were leaf phenology (e.g., evergreen, cold deciduous, drought-deciduous) and physiognomic class (e.g., forest, woodland, shrubland) of the plot, ocular estimation of percent cover of all vegetative cover at each of four height strata (ground cover [0.0 m], herbaceous [1.0m], shrub [1.0-5.0m], and canopy [>5.0m]), diameter at breast height (dbh) of the single largest tree in plot, ocular estimation of average tree height, and the number of snags present. Species-level variables recorded were percent cover of individual shrub and tree species at each of the four height strata. I summed the number of tree species found in each sampling plot and used this as a predictor variable named Tree Species Richness. I calculated an identical predictor variable using the number of shrub species found in each sampling plot and named this predictor variable Shrub Species Richness. Baccharis, willow, and grass species were each pooled for analyses due to the difficulty in identification and the withingenus similarity in habitat values each of these provide. 


\section{MODEL BUILDING AND ASSESSMENT}

Avian Species Selection: For this investigation, I selected 8 regionally common breeding passerine species: Black-headed Grosbeak, Orange-crowned Warbler, Pacific-slope Flycatcher, Song Sparrow, Spotted Towhee, Swainson's Thrush, Warbling Vireo, and Wilson's Warbler (Table 1). Scientific names, four letter banding acronym, and total number of detections are summarized in Table 1.

TABLE 1. Common names of species analyzed, scientific names, known riparian associated species, and RHJV focal species (BLM 1998, RHJV 2004), and total detections at all point counts stations $(n=96)$.

\begin{tabular}{llccc}
\hline \multicolumn{1}{c}{ SPECIES NAME } & \multicolumn{1}{c}{ SCIENTIFIC NAME } & RIPARIAN & RHJV FOCAL & TOTAL \\
\hline Black-headed Grosbeak & Pheucticus melanocephalus & $\mathrm{X}$ & $\mathrm{X}$ & 247 \\
Orange-crowned Warbler & Oreothlypis celata & $\mathrm{X}$ & & 281 \\
Pacific-slope Flycatcher & Empidonax difficilis & & & 295 \\
Song Sparrow & Melospiza melodia & $\mathrm{X}$ & $\mathrm{X}$ & 495 \\
Spotted Towhee & Pipilo maculatus & & & 255 \\
Swainson's Thrush & Catharus ustulatus & $\mathrm{X}$ & $\mathrm{X}$ & 223 \\
Warbling Vireo & Vireo gilvus & $\mathrm{X}$ & $\mathrm{X}$ & 312 \\
Wilson's Warbler & Wilsonia pusilla & $\mathrm{X}$ & $\mathrm{X}$ & 365 \\
\hline
\end{tabular}

These 8 species have close associations with riparian habitats. Orange-crowned Warbler, Song Sparrow, Wilson's Warbler, Black-headed Grosbeak, Swainson's Thrush, and Warbling Vireo have been identified as riparian obligate or dependent species, with $60-90 \%$ of their nests and abundance in riparian vegetation during the breeding season (BLM 1998). Pacific-slope Flycatcher is a sensitive Neotropical migrant species that breeds in dense, moist habitat in California (Lowether 2000). Black-headed Grosbeak, Song Sparrow, Swainson's Thrush, Warbling Vireo and Wilson's Warbler have been selected as Riparian Habitat Joint Venture Focal Species, as they breed primarily in riparian habitat and are of conservation concern due to population declines on the landscape (RHJV 2004, Chase and Geupel 2005). These species also have utility as 
monitoring tools due to their quick population response to management and restoration actions (RHJV 2004). While Spotted Towhee is not reliant solely on riparian habitat, studies have found strong relationships between this species abundance and riparian habitat attributes. Spotted Towhee abundance has also been correlated with riparian bird species richness in riparian vegetation, indicating that they are responding to similar habitat characteristics as other riparian species (Chase and Geupel 2005).

Habitat Variable Selection: For this analysis, I selected 19 of the 28 habitat variables collected in the field based on their relevance to land managers and restoration practitioners (Table 2). This subset of variables describes riparian forest structure, tree and shrub heterogeneity, and species composition at the plot scale, all of which are easily assessed and directly influenced by management activities or targeted in restoration efforts within the study region (MBNEP 2000, LCSLO 2010). Thus, these variables reflect modifications that are intentionally or inadvertently manipulated by land use or management. Also, 14 of these variables have been found to be important in predicting bird response to fine scale habitat features within riparian habitats on the California landscape (Nur et al. 2008, Heath and Ballard 2003), as summarized in Table 2. I also included an additional landscape-scale categorical predictor, Watershed, in order to test for a watershed effect, for a total of 20 analytical variables. I assessed all 19 quantitative variables for multicollinearity using Pearson's correlation coefficient (Whitlock and Schluter 2009), with a critical r-value of 0.6 (Appendix B, Table B1). Elevation correlated with both \% Cover Oak and \% Cover Bay, 
exceeding the critical $r$-value, and indicating the presence of a linear relationship.

I also reviewed scatter plots visually for the presence of obvious non-linear

relationships. These did not suggest the presence of any non-linear relationships

(i.e. quadratic) and so no additional tests of covariance were conducted.

TABLE 2. Subset of predictor variables evaluated for analysis, their unit of measure, inclusion in previous studies of riparian bird habitat associations, and disposition in final models of this study.

\begin{tabular}{|c|c|c|c|c|c|}
\hline HABITAT VARIABLE & CODE & $\begin{array}{l}\text { UNIT OF } \\
\text { MEASURE }\end{array}$ & $\begin{array}{c}\text { NUR ET AL. } \\
2008 \\
\end{array}$ & $\begin{array}{c}\text { HEATH AND } \\
\text { BALLARD } \\
2003 \\
\end{array}$ & $\begin{array}{l}\text { INCLUDED IN } \\
\text { SELECTED } \\
\text { MODEL(S) } \\
\end{array}$ \\
\hline \multicolumn{6}{|l|}{ Abiotic } \\
\hline Elevation & ELEV & meters & & $\bar{X}$ & $\bar{X}$ \\
\hline Corridor Width & CORW & feet & & $\mathrm{X}$ & $\mathrm{X}$ \\
\hline \multicolumn{6}{|l|}{ Structural } \\
\hline \% Cover Forb & $\%$ CFB & percent & $\bar{X}$ & $\bar{X}$ & $\bar{X}$ \\
\hline$\%$ Cover Grass & $\%$ CGR & percent & $x$ & $x$ & $x$ \\
\hline$\%$ Cover Shrub & $\% \mathrm{CSH}$ & percent & $x$ & $x$ & $x$ \\
\hline \% Cover Canopy & $\% C C A$ & percent & $X$ & $x$ & $x$ \\
\hline Tree Height Index & TRHI & meters & $X$ & $\mathrm{X}$ & $X$ \\
\hline $\mathrm{DBH}$ Index & $\mathrm{DBHI}$ & centimeters & $X$ & $\mathrm{X}$ & $\mathrm{X}$ \\
\hline \multicolumn{6}{|l|}{ Species level } \\
\hline Tree Species Richness & TSRI & count & $\bar{X}$ & $\bar{X}$ & $\bar{X}$ \\
\hline Shrub Species Richness & SSRI & count & $x$ & $x$ & $x$ \\
\hline$\%$ Cover Blackberry & $\% \mathrm{CBB}$ & percent & $x$ & & $x$ \\
\hline \% Cover Poison Oak & $\% \mathrm{CPO}$ & percent & & & $x$ \\
\hline$\%$ Cover Dogwood & $\% C D O$ & percent & & & $x$ \\
\hline$\%$ Cover Baccharis & $\%$ CBA & percent & & & \\
\hline \% Cover Willow & $\% \mathrm{CWI}$ & percent & $\mathrm{X}$ & $\mathrm{X}$ & $x$ \\
\hline$\%$ Cover Sycamore & $\% C S Y$ & percent & & & \\
\hline$\%$ Cover Cottonwood & $\% \mathrm{CCO}$ & percent & $X$ & $X$ & $x$ \\
\hline$\%$ Cover Oak & $\% \mathrm{COA}$ & percent & $x$ & $x$ & $x$ \\
\hline$\%$ Cover Bay & $\% \mathrm{CBA}$ & percent & & & $x$ \\
\hline \multicolumn{6}{|l|}{ Landscape Level } \\
\hline Watershed & WSHD & (categorical) & $x$ & $x$ & $x$ \\
\hline
\end{tabular}

Detection Probability: Measurement error and imperfect detection have been shown to introduce significant bias when estimating density from variable distance point count data (Alldredge et al. 2007, Simons et al. 2007, Simons et al. 2009, Johnson 2008). To address this concern, I used a truncated sampling plot (50 meter radius), and calculated indices of abundance, assuming perfect 
detection within the sampling plot. I tested this assumption using a removal model, which allowed us to estimate both components of detection probability (availability by sight or sound, and visual or auditory detection when available) (Farnsworth et al. 2002, Johnson 2007). Analyses were conducted using the program SURVIV (White 1982), following methods described in Farnsworth et al. (2002) for data derived from 2 point count time intervals (five minute counts divided into first 3 minutes and second 2 minutes). Results of this analysis indicated that detection probabilities were high $(\bullet 0.9)$ for all species within a $50 \mathrm{~m}$ radius plot, and in all cases a detection probability of 1.0 was included in the $95 \%$ confidence intervals (Appendix D, Table D1). I also calculated annual estimates of detection probability within a $50 \mathrm{~m}$ radius plot for each sampling year (20062009). For these analyses, annual partitioning of the dataset resulted in greater variability in the point estimates, and served to increase the breadth of confidence intervals. Despite this loss in statistical resolution, detection probabilities remained high $(\bullet 0.78)$, and a detection probability of 1.0 was included in the $95 \%$ confidence intervals for all species, for each year of the study period (Appendix D, Table D2). In summary, my results indicate that for the bird species selected, detection probability was high, and remained relatively constant throughout the study period. Therefore, I have incorporated the use of indices of abundance instead of attempting to estimate true density. To be specific: the assumption of equal detection probability across all species and all years, which is implicit in the use of an index, is apparently not violated. 
Treatment of the Response Variables: I used one index of bird abundance as the response variable for regression analyses. In the case of four species (Pacificslope Flycatcher, Song Sparrow, Swainson's Thrush, Wilson's Warbler), detections within a 50 meter radius were summed across all years at each point (Nur et al. 1999). For the remaining four species (Black-headed Grosbeak, Orange-crowned Warbler, Spotted Towhee, Warbling Vireo), I modified the above index as followings: natural logarithm (In) * (summed count detections + 1). This log transformation was applied based on the error structure of the distribution of summed detections for each of these species, and allowed for normalization of the residuals in regression models (Nur et al. 1999). Statistical Analysis Including Model Selection: Prior to the development of candidate models, I used residual sum of squares values from univariate regressions to identify and rank variables associated with bird abundance (Hosmer and Lemeshow 2000). This ranking procedure provided a quantitative approach to selecting a subset of predictors for inclusion in candidate models. The top five covariates and an additional categorical predictor, watershed, were used in defining all possible candidate models for modeling species response.

I used simple linear regression to model the relative abundance of the selected species using fine scale habitat variables identified by the sums of squares analysis. I tested the normality of residuals of the full model sets. Normality plots with Ryan Joiner test statistics and p-values are summarized in Appendix B (Figure B1-B10). I tested for departures of equal variance in the response variable using Levene's Test, and reviewed scatterplots. I did not find 
any pervasive violation of this assumption, with the exception of bird response to $\%$ Cover Baccharis. Levene's test statistics $(W)$ and $p$-values are summarized in Appendix B (Table B2). Models were ranked using Akaike's Information Criteria $(\mathrm{AIC})$, corrected for small sample size $\left(\mathrm{AIC}_{\mathrm{c}}\right)$ and over-dispersion $\left(\mathrm{QAIC}_{\mathrm{c}}\right)$ when appropriate (Burnham and Anderson 2002). These extended criteria include a bias correction term which addresses AIC's tendency to perform poorly when the ratio of sample size to number of parameters is small (i.e. $n / K<40)($ Burnham and Anderson 2002). I also evaluated the relative importance of predictor variables using summed Akaike weights $\left(w_{i}\right)$ (Burnham and Anderson 2002). All analyses were conducted in the statistical package $R$ ( $R$ Development Core Team 2010).

Linear regression has been widely used to assess bird habitat relationships despite poor predictive and explanatory performance. (Morrison et al. 1987, Mauer 1986). In order to address species-level questions, and have results which were comparable to the current body of literature on bird-habitat associations, I have taken a consistent analytical approach by using general linear regression.

\section{RESULTS}

Avian Assemblage: I detected one hundred and twenty-five species using variable distance point count surveys during the four year study period (Table C1). The avian assemblage throughout the study region varies from other regions of the California landscape. Through surveys, I encountered Band-tailed Pigeon breeding within the riparian habitats within the county. This species is 
currently absent from Central Valley riparian where it previously occurred, likely due to hunting-driven population declines and loss of habitat (Grinnell and Miller 1944). Also, Brown-headed Cowbird abundance was extremely low compared to other regions (Melcer et al. 2006, Lindgren et al. 2006), and consistent with previous studies of Central Coast populations (Farmer 1999). Chestnut-backed Chickadee is an extremely abundant permanent resident within riparian vegetation communities throughout the study region. This species is absent from Central Valley riparian habitats with the exception of a few wintering birds that travel down corridors out of the coast range (Lindgren et al. 2006). Pacific-slope Flycatcher is associated with shaded, moist habitats near water sources. I found this species to be a common throughout the study region. I found both Swainson's Thrush and Warbling Vireo to be abundant throughout the study area. These species have suffered significant range contractions as breeders in southern California and the Central Valley where they were historically found as a common summer residents from late April through August (Grinnell and Miller 1944). Swainson's Thrush has also suffered extirpation from most of the Sierra Nevada, where two sub-species were historically common (Grinnell and Miller 1944). I also routinely detected MacGillivray's Warbler, Cassin's Vireo, Western Tanager, and Olive-sided Flycatcher at the Cerro Alto and Santa Rita study sites throughout the study period. These species are typically associated with higher elevations and pine forests. I failed to detect State or federal threatened or endangered species during the study period, however; I detected Yellow- 
breasted Chat, a Species of Special Concern (Shuford and Gardali 2008) at several sites, over several years.

Focal Species: I detected Black-headed Grosbeak, Orange-crowned Warbler, Pacific-slope Flycatcher, Song Sparrow, Spotted Towhee, Swainson's Thrush, Warbling Vireo and Wilson's Warbler at all sites, in high abundance. Each of these species had high detection rates within 50 meters of the observer, and was used in the more detailed analysis of bird response to habitat features (Table 1). Blue Grosbeak, Ash-throated Flycatcher, Brown-headed Cowbird, Red-winged Blackbird, House Wren, American Goldfinch, Western Kingbird, Bullock's Oriole, Lazuli Bunting, Western Wood-pewee, and Yellow Warbler have been used in recent studies on fine-scale habitat associations; however, had low detection rates within 50 meters during this study.

Habitat Surveys: Sampling plots were located at elevations spanning from 1 to 365 meters above sea level. The width of riparian vegetation varied from 29 to 290 meters across all sampling locations. Through relevé surveys, I detected approximately 114 species of plants (Appendix C, Tables C2-C4), yet many were identified only to genus. I found non-native plant species presence at the study sites was low compared to other riparian areas in California. Native creeping blackberry was the dominant species at sampling plots; Himalayan blackberry (Rubis discolor) was absent from field sites. Fremont's cottonwood (Populus fremontia) is found east of the study region in the Salinas Valley; black cottonwood was the cottonwood species present within the study region. 
Model Selection: For each of the eight focal species, I present the model selection results (Tables 3 and 6-12). I identify all of the models, out of those tested, that are most parsimonious and likely to have produced the observed data (i.e. models with $\mathrm{AlC}_{\mathrm{c}}<2.0$ ). The subset of models selected for each species represent the models with the most empirically support, with other models having considerably less or essentially no support $\left(\mathrm{AIC}_{\mathrm{c}}<2.0\right.$; Burnham and Anderson 2002). Appendix E, Table E1 includes the complete output of the model selection analysis for all 63 candidate models. In addition to the results for each individual species, I also present predictor variables selected from models across all species and whether they had a positive or negative correlation with the abundance of the individual species (Table 4). The relative importance of each covariate in a model can be inferred by assessing the summed $\mathrm{w}_{\mathrm{i}}$ (Burnham and Anderson 2002). Therefore, as a summary, I present the relative importance values of each covariate across all models selected for all species (Table 5). Black-headed Grosbeak: Candidate models included all possible combinations of: Tree Species Richness, \% Cover Blackberry, \% Cover Forb, \% Cover Canopy, and \% Cover Dogwood. I found no linear correlations exceeding the critical value of $r=0.6$ between these variables (Appendix B, Table B1). Watershed was also included as a categorical predictor, resulting in the evaluation of 63 models using $\mathrm{AIC}_{\mathrm{c}}$. Table 3 provides a summary of the 3 highest ranked models. 
TABLE 3. Summary of three models of the 63 tested for Black-headed Grosbeak with AICc values <2.0, including model terms, number of parameters $(K)$, log likelihood value, $\mathrm{AIC}$ and $\mathrm{AICc}$ scores, change in AICc score ( $\mathrm{AICc}$ ) between models, and AICc weight (Wi).

\begin{tabular}{lcccccc}
\hline \multicolumn{1}{c}{ MODEL } & $K$ & $\log (\mathcal{L})$ & $\mathrm{AIC}$ & $\mathrm{AlC}_{\mathrm{c}}$ & $\Delta_{\mathrm{i}} \mathrm{AlC}_{\mathrm{c}}$ & $\mathrm{W}_{\mathrm{i}}$ \\
\hline $\mathrm{TSRI}+\% \mathrm{CBB}+\% \mathrm{CFB}+\% \mathrm{CCA}+\% \mathrm{CDO}$ & 7 & -80.878 & 175.756 & 177.029 & 0.000 & 0.147 \\
$\mathrm{TSRI}+\% \mathrm{CBB}+\% \mathrm{CCA}+\% \mathrm{CDO}$ & 6 & -82.056 & 176.113 & 177.057 & 0.028 & 0.145 \\
$\% \mathrm{CBB}+\% \mathrm{CFB}+\% \mathrm{CCA}+\% \mathrm{CDO}+$ WSHD & 13 & -73.738 & 173.477 & 177.916 & 0.887 & 0.094 \\
\hline
\end{tabular}

Tree Species Richness was included in 2 models, and had a positive correlation with the abundance index (Table 4). \% Cover Blackberry, \% Cover Forb, \% Cover Canopy and \% Cover Dogwood were included in all 3 top models, all having positive correlations with Black-headed Grosbeak abundance with the exception of \% Cover Dogwood (Table 4). Watershed was included in only one model.

TABLE 4. Summary of variables used (based on sums of squares selection) which were regarded as possible predictor variables. For each of the variables which were selected in a model, the direction of their regression line slope indicates the nature of the correlation between each bird species and habitat variables.

\begin{tabular}{lcccccccc}
\hline HABITAT VARIABLE & BHGR & OCWA & PSFL & SOSP & SPTO & SWTH & WAVI & WIWA \\
\hline Watershed Included: & yes & yes & no & no & yes & yes & yes & yes \\
Elevation & & & & $\downarrow$ & & $\downarrow$ & & \\
Corridor Width & & $\uparrow$ & & & & & & \\
\% Cover Forb & $\uparrow$ & & & $\uparrow$ & & $\downarrow$ & & \\
\% Cover Grass & & & $\downarrow$ & & & $\uparrow$ & & $\uparrow$ \\
\% Cover Shrub & & $\uparrow$ & & & & & & $\uparrow$ \\
\% Cover Canopy & $\uparrow$ & & $\uparrow$ & & & & $\uparrow$ & \\
Tree Height Index & & & & & & & $\uparrow$ & \\
$\begin{array}{l}\text { DBH Index } \\
\text { Tree Species Richness }\end{array}$ & $\uparrow$ & & $\uparrow$ & & & & $\uparrow$ & \\
$\begin{array}{l}\text { Shrub Species Richness } \\
\text { \% Cover Blackberry }\end{array}$ & $\uparrow$ & & & $\downarrow$ & $\uparrow$ & & $\uparrow$ & \\
\% Cover Poison Oak & & & & $\uparrow$ & & & $\uparrow$ & \\
\% Cover Dogwood & $\downarrow$ & & & $\downarrow$ & & & & $\uparrow$ \\
\% Cover Willow & & & $\downarrow$ & & & & & $\uparrow$ \\
\% Cover Cottonwood & & $\downarrow$ & & & & & & \\
\% Cover Oak & & & $\uparrow$ & & & & & $\downarrow$ \\
\% Cover Bay & & & & & & &
\end{tabular}

$\uparrow$ indicates a positive regression line slope; $\downarrow$ indicates a negative regression line slope 
For Black-headed Grosbeak, the order of predictors ranked by their summed $w_{i}$ was \% Cover Blackberry, \% Cover Canopy, Tree Species Richness, \% Cover Dogwood, \% Cover Forb and Watershed (Table 5).

TABLE 5. Table of the summed $W_{i}$ values (derived from 63 models tested for each species) for each of the variables included in the final model sets.

\begin{tabular}{|c|c|c|c|c|c|c|c|c|}
\hline HABITAT VARIABLE & BHGR & OCWA & PSFL & SOSP & SPTO & SWTH & WAVI & WIWA \\
\hline Watershed & 0.414 & 1.000 & & & 0.967 & 1.000 & 1.000 & 0.521 \\
\hline Elevation & & & & 0.444 & & 0.527 & & \\
\hline Corridor Width & & 0.322 & & & & & & \\
\hline$\%$ Cover Forb & 0.654 & & & 0.393 & & & & \\
\hline$\%$ Cover Grass & & & 0.990 & & & 0.320 & & \\
\hline \% Cover Shrub & & 0.412 & & & & 0.699 & & 0.362 \\
\hline \% Cover Canopy & 0.783 & & 0.509 & & & & & 0.779 \\
\hline Tree Height Index & & & & & & & 0.349 & \\
\hline DBH Index & & & & & & & 0.404 & \\
\hline Tree Species Richness & 0.708 & & 0.635 & & & & 0.270 & \\
\hline Shrub Species Richness & & & & 0.343 & 0.717 & & & \\
\hline$\%$ Cover Blackberry & 0.830 & & & 0.453 & & & 0.602 & \\
\hline \% Cover Poison Oak & & & & 0.312 & & & & \\
\hline \% Cover Dogwood & 0.680 & & & & 0.631 & & & 0.780 \\
\hline \% Cover Willow & & & 0.682 & & & & & 0.279 \\
\hline$\%$ Cover Cottonwood & & 0.413 & & & & & & \\
\hline \% Cover Oak & & & 0.510 & & & & & \\
\hline$\%$ Cover Bay & & & & & & & & 0.677 \\
\hline
\end{tabular}

Orange-crowned Warbler: Candidate models included all possible combinations of: \% Cover Shrub, Corridor Width, Shrub Species Richness, \% Cover Dogwood, and \% Cover Cottonwood. I found no linear correlations exceeding the critical value of $r=0.6$ between these variables (Appendix B, Table B1). Watershed was also included as a categorical predictor, resulting in the evaluation of 63 models using $\mathrm{AlC}_{\mathrm{c}}$. Table 6 provides a summary of the 6 highest ranked models. Watershed was included in all selected models. \% Cover Shrub was included in three models and had a positive correlation with the abundance index (Table 4). Corridor Width and \% Cover Cottonwood were included in 2 of the 6 selected models, the former positively associated and the latter negatively associated with abundance (Table 4). The order of predictors ranked by their 
summed $\mathrm{w}_{\mathrm{i}}$ was Watershed, \% Cover cottonwood, \% Cover Shrub, and Corridor Width (Table 5). Both \% Cover Shrub and \% Cover Cottonwood shared similar $\mathrm{w}_{\mathrm{i}}$ values.

TABLE 6. Summary of six models of the 63 tested for Orange-crowned Warbler with AICc values <2.0, including model terms, number of parameters $(K)$, log likelihood value, AIC and AICc scores, change in AICc score ( AICc) between models, and AICc weight (Wi).

\begin{tabular}{lcccccc}
\hline \multicolumn{1}{c}{ MODEL } & $K$ & $\log (\mathcal{L})$ & $\mathrm{AIC}$ & $\mathrm{AlC}_{\mathrm{c}}$ & $\Delta_{\mathrm{i}} \mathrm{AlC}_{\mathrm{c}}$ & $\mathrm{W}_{\mathrm{i}}$ \\
\hline WSHD & 9 & -75.539 & 169.079 & 171.172 & 0.000 & 0.137 \\
\%CCO + WSHD & 10 & -74.556 & 169.112 & 171.700 & 0.529 & 0.105 \\
$\% \mathrm{CSH}+$ WSHD & 10 & -74.748 & 169.496 & 172.084 & 0.912 & 0.087 \\
\%CSH +\%CCO + WSHD & 11 & -73.701 & 169.401 & 172.544 & 1.372 & 0.069 \\
CORW + WSHD & 10 & -75.027 & 170.054 & 172.642 & 1.470 & 0.066 \\
\%CSH + CORW + WSHD & 11 & -73.966 & 169.931 & 173.074 & 1.902 & 0.053 \\
\hline
\end{tabular}

Pacific-slope Flycatcher: Candidate models included all possible combinations of: \% Cover Grass, Tree Species Richness, \% Cover Oak, \% Cover Canopy, and \% Cover Willow. I found no linear correlations exceeding the critical value of $r=0.6$ between these variables (Appendix B, Table B1). Watershed was also included as a categorical predictor, resulting in the evaluation of 63 models using $\mathrm{AlC}_{\mathrm{c}}$. Table 7 provides a summary of the 5 highest ranked models. \% Cover Grass was included in all models, while Tree Species Richness was included in four models of the top five models. \% Cover Oak and \% Cover Willow were included in three models and \% Canopy Cover was included in two of the top five models. All were positively associated with abundance except \% Cover Grass and \% Cover Willow (Table 4). Watershed was not included in any of the selected models. The order of predictors ranked by their summed $w_{i}$ was $\%$ Cover Grass, \% Cover Willow, Tree Species Richness, \% Cover Oak and \% Cover Canopy, the latter two having similar summed weights (Table 5). 
TABLE 7. Summary of five models of the 63 tested for Pacific-slope Flycatcher with AICc values <2.0, including model terms, number of parameters $(K)$, log likelihood value, $\mathrm{AIC}$ and $\mathrm{AICc}$ scores, change in AICc score ( $\mathrm{AICc}$ ) between models, and AICc weight (Wi).

\begin{tabular}{lcccccc}
\hline \multicolumn{1}{c}{ MODEL } & $K$ & $\log (\mathcal{L})$ & $\mathrm{AlC}$ & $\mathrm{AlC}_{\mathrm{c}}$ & $\Delta_{\mathrm{i}} \mathrm{AlC}_{\mathrm{c}}$ & $\mathrm{W}_{\mathrm{i}}$ \\
\hline \%CGR + \%CCA + \%CWI & 5 & -184.385 & 378.770 & 379.437 & 0.000 & 0.165 \\
\%CGR + TSRI + \%COA & 5 & -184.395 & 378.789 & 379.456 & 0.016 & 0.163 \\
\%CGR + TSRI + \%COA + \%CCA & 6 & -183.438 & 378.875 & 379.819 & 0.379 & 0.136 \\
\%CGR + TSRI + \%COA + \%CWI & 6 & -183.876 & 379.752 & 380.696 & 1.256 & 0.088 \\
\%CGR + TSRI + \%CWI & 5 & -185.306 & 380.612 & 381.278 & 1.838 & 0.066 \\
\hline
\end{tabular}

Song Sparrow: Candidate models included all possible combinations of: \% Cover Blackberry, Elevation, \% Cover Forb, Shrub Species Richness, and \% Cover Poison Oak. I found no linear correlations exceeding the critical value of $r$ $=0.6$ between these variables (Appendix $\mathrm{B}$, Table B1). Watershed was also included as a categorical predictor, resulting in the evaluation of 63 models using

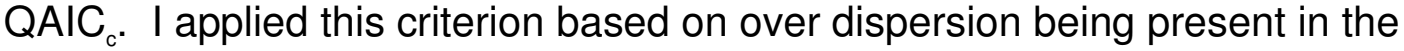
response variable (Burnham and Anderson 2002). Table 8 provides a summary of the eleven highest ranked models. \% Cover Blackberry was included in 5 of 11 models, while \% Cover Forb and Shrub Species Richness were included in 4 models. Elevation was included in 3 of 11 models, \% Cover Poison Oak was included in 2 models. Watershed was not included in any of the higher ranking models. Only \% Cover Forb and \% Cover Blackberry had positive correlation with the abundance indices (Table 4). The order of predictors ranked by their summed $w_{i}$ was \% Cover Blackberry, Elevation, \% Cover Forb, Shrub Species Richness, and \% Cover Poison Oak (Table 5). 
TABLE 8. Summary of eleven models of the 63 tested for Song Sparrow, with AICc values $<2.0$, including model terms, number of parameters $(K)$, log likelihood value, AIC and AICc scores, change in AICc score ( $\mathrm{IICc}$ ) between models, and AICc weight (Wi).

\begin{tabular}{|c|c|c|c|c|c|c|}
\hline MODEL & $K$ & $\log (\Omega)$ & AIC & QAIC $_{c}$ & ${\Delta \Delta_{\mathrm{i}} \mathrm{QAIC}_{\mathrm{c}}}$ & $\bar{W}_{i}$ \\
\hline \%CBB & 4 & -233.157 & 472.315 & 82.258 & 0.000 & 0.092 \\
\hline ELEV & 4 & -233.845 & 473.691 & 82.476 & 0.218 & 0.083 \\
\hline ELEV + \%CFB & 5 & -228.345 & 464.691 & 82.962 & 0.704 & 0.065 \\
\hline$\%$ CFB & 4 & -235.544 & 477.088 & 83.014 & 0.756 & 0.063 \\
\hline SSRI & 4 & -235.648 & 477.297 & 83.047 & 0.789 & 0.062 \\
\hline$\% \mathrm{CBB}+\mathrm{ELEV}$ & 5 & -228.630 & 465.259 & 83.052 & 0.794 & 0.062 \\
\hline$\% \mathrm{CBB}+\% \mathrm{CPO}$ & 5 & -230.778 & 469.556 & 83.732 & 1.474 & 0.044 \\
\hline$\%$ СPO & 4 & -237.927 & 481.853 & 83.768 & 1.510 & 0.043 \\
\hline$\% C B B+S S R I$ & 5 & -230.911 & 469.822 & 83.774 & 1.516 & 0.043 \\
\hline$\%$ CBB $+\%$ CFB & 5 & -230.927 & 469.854 & 83.779 & 1.521 & 0.043 \\
\hline$\% \mathrm{CFB}+\mathrm{SSRI}$ & 5 & -231.997 & 471.994 & 84.118 & 1.860 & 0.036 \\
\hline
\end{tabular}

Spotted Towhee: Candidate models included all possible combinations of:

Elevation, Shrub Species Richness, \% Cover Dogwood, \% Cover Poison Oak, and \% Cover Canopy. I found no linear correlations exceeding the critical value of $r=0.6$ between these variables (Appendix B, Table B1). Watershed was also included as a categorical predictor, resulting in the evaluation of 63 models using $\mathrm{AIC}_{\mathrm{c}}$. Table 9 provides a summary of the 2 highest ranking models. Watershed and Shrub Species Richness were included in both selected models, and \% Cover Dogwood was included in 1 of 2 models. Shrub Species Richness had positive a correlation and \% Cover Dogwood had negative a correlation with the abundance indices (Table 4). The order of predictors ranked by their summed $w_{i}$ was Watershed, Shrub Species Richness, \% Cover Dogwood, (Table 5).

TABLE 9. Summary of two models of the 63 tested for Spotted Towhee, with AICc values $<2.0$, including model terms, number of parameters $(K)$, log likelihood value, AIC and AICc scores, change in AICc score ( $\mathrm{AICc}$ ) between models, and AlCc weight (Wi).

\begin{tabular}{lcccccc}
\hline \multicolumn{1}{c}{ MODEL } & $K$ & $\log (\mathcal{L})$ & $\mathrm{AIC}$ & $\mathrm{AlC}_{\mathrm{c}}$ & $\Delta_{\mathrm{i}} \mathrm{AlC}_{\mathrm{c}}$ & $\mathrm{W}_{\mathrm{i}}$ \\
\hline $\mathrm{SSRI}+\% \mathrm{CDO}+$ WSHD & 11 & -184.385 & 142.128 & 145.271 & 0.000 & 0.207 \\
SSRI + WSHD & 10 & -184.395 & 143.887 & 146.475 & 1.205 & 0.114 \\
\hline
\end{tabular}


Swainson's Thrush: Candidate models included all possible combinations of: Elevation, \% Cover Shrub, \% Cover Willow, \% Cover Grass, and Tree Species Richness. I found no linear correlations exceeding the critical value of $r=0.6$ between these variables (Appendix B, Table B1). Watershed was also included as a categorical predictor, resulting in the evaluation of 63 models using $\mathrm{AlC}_{\mathrm{c}}$. Table 10 provides a summary of the 6 highest ranked models. Watershed was included in all final models. \% Cover Shrub was included in 4 of the selected models, and was positively correlated with the index of abundance. Elevation was included in 3 of the selected models, and was negatively correlated with the index of abundance. \% Cover Grass was included in 2 selected models, and was negatively correlated with the index of abundance (Table 4). The order of predictors ranked by their summed $w_{i}$ was Watershed, \% Cover Shrub, Elevation, and \% Cover Grass (Table 5).

TABLE 10. Summary of six models of those the 63 for Swainson's Thrush, with AICc values <2.0, including model terms, number of parameters $(K)$, log likelihood value, AIC and AICc scores, change in AICc score ( AICc) between models, and AICc weight (Wi).

\begin{tabular}{lcccccc}
\hline \multicolumn{1}{c}{ MODEL } & $K$ & $\log (\ell)$ & $\mathrm{AlC}$ & $\mathrm{AlC}_{\mathrm{c}}$ & $\Delta_{\mathrm{i}} \mathrm{AlC}_{\mathrm{c}}$ & $\mathrm{W}_{\mathrm{i}}$ \\
\hline ELEV + \%CSH + WSHD & 11 & -160.611 & 343.222 & 343.222 & 0.000 & 0.150 \\
\%CSH + WSHD & 10 & -161.948 & 343.897 & 343.897 & 0.120 & 0.141 \\
ELEV + \%CSH + \%CGR +WSHD & 12 & -160.064 & 344.128 & 344.128 & 1.522 & 0.070 \\
ELEV + WSHD & 10 & -162.814 & 345.627 & 345.627 & 1.851 & 0.059 \\
\%CSH + \%CGR + WSHD & 11 & -161.542 & 345.085 & 345.085 & 1.863 & 0.059 \\
WSHD & 9 & -164.113 & 346.225 & 346.225 & 1.953 & 0.056 \\
\hline
\end{tabular}

Warbling Vireo: Candidate models included all possible combinations of: \% Cover Blackberry, DBH Index, Tree Species Richness, Tree Height, and \% Cover Forb. I found no linear correlations exceeding the critical value of $r=0.6$ between these variables (Appendix B, Table B1). Watershed was also included 
as a categorical predictor, resulting in the evaluation of 63 models using $\mathrm{AIC}_{\mathrm{c}}$. Table 11 provides a summary of the 7 highest ranked models. Watershed was included in all seven selected models, while \% Cover Blackberry was included in 4 selected models. DBH Index and Tree Height Index were included in 2 models, and Tree Species Richness was included in only one selected model. All variables were positively correlated with the index of abundance for Warbling Vireo (Table 4). The order of predictors ranked by their summed $w_{i}$ was Watershed, \% Cover Blackberry, DBH Index, Tree Height, Tree Species Richness, and \% Cover Forb (Table 5).

TABLE 11. Summary of six models of the 63 tested for Warbling Vireo with AICc values $<2.0$, including model terms, number of parameters $(K)$, log likelihood value, $\mathrm{AIC}$ and $\mathrm{AICc}$ scores, change in AICc score ( $\mathrm{AICc}$ ) between models, and AlCc weight $(\mathrm{Wi})$.

\begin{tabular}{lcccccc}
\hline \multicolumn{1}{c}{ MODEL } & $K$ & $\log (\mathcal{L})$ & $\mathrm{AIC}$ & $\mathrm{AlC}_{\mathrm{c}}$ & $\Delta_{\mathrm{i}} \mathrm{AlC}_{\mathrm{c}}$ & $\mathrm{W}_{\mathrm{i}}$ \\
\hline \%CBB + WSHD & 10 & -78.606 & 177.211 & 179.799 & 0.000 & 0.127 \\
\%CBB + DBHI + WSHD & 11 & -77.669 & 177.337 & 180.480 & 0.681 & 0.090 \\
\%CBB + TRHI + WSHD & 11 & -77.744 & 177.488 & 180.630 & 0.831 & 0.083 \\
WSHD & 9 & -80.461 & 178.923 & 181.016 & 1.216 & 0.069 \\
DBHI + WSHD & 10 & -79.214 & 178.428 & 181.016 & 1.217 & 0.069 \\
\%CBB + TSRI & 11 & -78.130 & 178.261 & 181.404 & 1.604 & 0.057 \\
TRHI + WSHD & 10 & -79.445 & 178.891 & 181.479 & 1.680 & 0.055 \\
\hline
\end{tabular}

Wilson's Warbler: Candidate models included all possible combinations of: \% Cover Dogwood (1), \% Cover Willow (2), \% Cover Shrub (3), \% Cover Canopy (4), and \% Cover Bay (5). I found no linear correlations exceeding the critical value of $r=0.6$ between these variables (Appendix B, B1). Watershed (6) was also included as a categorical predictor, resulting in the evaluation of 63 models using $\mathrm{AlC}_{\mathrm{c}}$. Table 12 provides a summary of the 4 highest ranked models. $\%$ Cover Dogwood and \% Cover Canopy were included in all selected models, and were positively associated with Wilson's Warbler abundance indices (Table 4). 
$\%$ Cover Bay was included in 3 selected models, and had a negative correlation with the abundance indices (Table 4). \% Cover Willow, \% Cover Shrub, and Watershed were each included in only one of the selected models, and the latter two were positively correlated with Wilson's Warbler abundance indices (Table 4). The order of predictors ranked by their summed $w_{i}$ was $\%$ Cover Dogwood, \% Cover Canopy, \% Cover Bay, Watershed, \% Cover Shrub, and \% Cover Willow (Table 5).

TABLE 12. Summary of six models of the 63 tested for Wilson's Warbler with AICc values $<2.0$, including model terms, number of parameters $(K)$, log likelihood value, AIC and AICc scores, change in AICc score ( $\mathrm{AICc}$ ) between models, and AICc weight (Wi).

\begin{tabular}{lcccccc}
\hline \multicolumn{1}{c}{ MODEL } & $K$ & $\log (\mathcal{L})$ & $\mathrm{AIC}$ & $\mathrm{AlC}_{\mathrm{c}}$ & $\Delta_{\mathrm{i}} \mathrm{AlC}_{\mathrm{c}}$ & $\mathrm{W}_{\mathrm{i}}$ \\
\hline$\% \mathrm{CDO}+\% \mathrm{CCA}+\% \mathrm{CBA}$ & 5 & -191.590 & 393.181 & 393.848 & 0.000 & 0.155 \\
$\% \mathrm{CDO}+\% \mathrm{CSH}+\% \mathrm{CCA}+\% \mathrm{CBA}$ & 6 & -190.510 & 393.020 & 393.964 & 0.116 & 0.146 \\
$\% \mathrm{CDO}+\% \mathrm{CCA}+$ WSHD & 11 & -185.084 & 392.167 & 395.310 & 1.463 & 0.074 \\
$\% \mathrm{CDO}+\% \mathrm{CWI}+\% \mathrm{CCA}+\% \mathrm{CBA}$ & 6 & -191.436 & 394.872 & 395.816 & 1.969 & 0.058 \\
\hline
\end{tabular}

\section{DISCUSSION}

During May and June of 2006-2009, I conducted bird and habitat surveys $(n=96)$ within riparian habitat at 8 field sites along the central California coast between Cambria and Pismo Beach. Using these data, I developed speciesspecific correlative (simple linear) models for 8 bird species using fine-scale habitat characteristics, and evaluated these models using an information theoretic approach. I also assessed the direction of effect and importance of each habitat variable in describing bird response to these fine scale habitat characters.

Implications to Land Management and Restoration Efforts: Despite their high quality habitat features, and the continued persistence of breeding populations of 
bird species which are suffering decline and extirpation in other areas of the coast, the study region's riparian vegetation communities have received little attention from conservation directives with respect to landbirds (e.g. RHJV 2004, CWC 2002, Cooper 2004, TNC 2006). This is concerning in light of the fact that less than $7 \%$ of riparian habitat in the central coast bioregion is managed for conservation (Davis et al. 1998). Heightened recognition of the riparian resources present within the study region is needed. In the interest of riparian landbird conservation, land managers and conservation practitioners should address the protection and restoration of habitats for a broad suite of species using region specific criteria (Nur et al. 2008). My study indicates that for 8 species of landbirds in central coast California, efforts should be directed at protecting and restoring the presence of and/or processes that create: diverse tree and shrub communities; dense tree, shrub and forb structure; extensive distribution of native blackberry, mixed distributions of red and arroyo willow and red-stem dogwood; a range of age classes of trees. Smaller creeks within the region (Morro Bay tributaries, Los Osos Valley, Guadalupe Valley) offer significant opportunities for enhancement of the vegetation communities currently limited by agriculture. Larger watersheds such as the Big Sur, Salinas, Nacimiento, and Carmel Rivers also require protection and offer significant restoration potential (RHJV 2004).

Regional variation: What is the overlap in explanatory variables across studies that have investigated habitat predictors of abundance in California's riparian bird communities? In comparison to Nur et al. (2008), the overlap is poor at best. 
There are two fundamental differences: the avian communities and the useful predictors of abundance. The 8 most common species in this data set are not the 8 most common species in Nur et al. (2008). In fact, there is a subset of species that do not even occur in both data sets. For species that do co-occur and are analyzed in both studies, the predictive variables differ. For example, for Black-headed Grosbeak, only one variable is recovered as predictive by both studies (\% Cover Herb Cover). I found 4 explanatory variables that they do not, and conversely they find 2 explanatory variables. Some of this is due to a lack of the same variables being included in both studies but, it is not the entire explanation since 10 variables are shared between the two studies (17 variables in their study and 20 in this one). Another possibility, for which I do not know the effect, is that I have assessed the detection probability, and used species that all have probabilities that are consistently high and close to 1 , whereas, Nur et al. (2008) have simply used an index of abundance. Therefore, there may be bias inherent in trying to predict the number of detections when the detections differ in their probabilities. Therefore adjusting for, or at least assessing detection probability, makes the results of these types of studies more directly comparable because abundances would be a metric of the same phenomenon (abundance, rather than detection probability $\mathrm{x}$ abundance). I find it informative that the second species that is analyzed by both of these studies, Spotted Towhee, shows no overlap in the explanatory variables identified. This seems to show that just as scientists should accept regional variation in the composition of riparian avifaunas, they should probably expect regional variation in the 
relationship between habitat variables and avian abundance.

Conservation Implications and Future Research Needs: Several of the species treated in my analyses are experiencing population decline or have been extirpated regionally within California riparian habitats. Wilson's Warbler, once a common breeder in coastal riparian habitats in southern California, has suffered range contractions and extirpation along the coast south of the study area (Dawson 1923, Grinnell and Miller 1944, Small 1994, Dunn and Garrett 1997, Sauer et al. 2008). Populations of Warbling Vireo have been reduced and extirpated throughout southern California and the Central Valley (Sibley 1940, Grinnell and Miller 1944, Gaines 1974, Garrett and Dunn 1981, Unitt 1984), and are suffering poor productivity in coastal habitats and the Sierra Nevada (Lindgren 2006, Purcell 2006, Smith et al. 2005). Swainson's Thrush has suffered similar range contractions and extirpation in southern California and throughout the Central Valley due to riparian habitat loss (Grinnell and Miller 1944, Sauer et al. 2008, Bent 1949, Verner and Boss 1980). Multiple subspecies of Song Sparrow associated with wetland and riparian habitats have declined significantly throughout the Central Valley and Sacramento-San Joaquin Delta (Shuford and Gardali 2008).

An understanding of ecological requirements is a critical information need for effective conservation and recovery of species within a managed landscape (Shuford and Gardali 2008). Previous studies of bird response to fine scale habitat features in California have occurred in systems that have been significantly degraded by urban and water resource development, agriculture, 
and non-native species invasions (Nur et al. 2008, Heath and Ballard 2003). The watersheds within the study area may harbor important source populations for the region, and could be of critical importance as restoration activities are implemented in areas such as the Salinas Valley or the San Francisco Bay Area. The watersheds have also provided an opportunity to investigate the regional ecological requirements of these bird species where they are common breeders and present in high quality riparian habitat. That said, information on presence and abundance does not directly translate to an understanding of population viability (Robertson and Hutto 2007). Continued annual point count surveys will provide long-term population trajectory information, and aid in identifying regional declines. The implementation of methods allowing the estimation of demographic parameters such as nesting success, recruitment, and survival is needed, however, to effectively understand the demographic role and source population potential of these populations (Martin and Geupel 1993, Desante and Rosenburg 1998). Implications and limitations of analytical approach: Recent studies have resulted in a better understanding of the effects of measurement error-induced bias resulting from the use of aural survey methods, and the resulting inaccuracies when these methods are used to estimate avian abundance metrics (Johnson 2008). This issue has implications for every study incorporating aural survey methods and corrections for imperfect detection. Despite these challenges, there may be a large suite of important species for which detection probability may be 
high (i.e. close to 1), and where the bird response signal to environmental covariates outweighs the effects of imperfect detection.

Also, a more robust assessment of detection probability could be undertaken with the addition of sampling periods during a point count survey (i.e. additional 2 minute time periods added on to the point count). As analyzed, this method uses only a two-sample (2 time period) framework, and requires the assumption that detection probability remains constant between the two time periods. Even with adjustments to the equations to account for asymmetry in the time periods, this assumption may not be fully met. Finally, linear regression tests only for linear relationships between the response variable and covariates. Cases where birds do not respond monotonically across the entire distribution of covariates can be problematic for this analytical approach (Meents et al. 1983, Young 1996). Implications and Limitations of Habitat Analyses: Bird species response to fine scale habitat features can vary by region within riparian habitats (Nur et al. 2008, Heath and Ballard 2003). My findings fill an information gap by providing the first regional data for this part of California and by offering a summary of the regional habitat associations of riparian birds within riparian habitats in a previously unstudied region of California.

Watershed was included in the models for 6 of the 8 species, suggesting that there may be either unmeasured variables having an effect on the bird abundance indices in some models or even sub-region scale variation. The importance of spatial scale in habitat association modeling has been 
demonstrated by various investigations, and Saab (1999) found landscape scale effects to be more important than fine scale features in predicting bird response. Importantly, I allowed for landscape level effects, though I did not try to model them empirically. But, above and beyond significant small-scale effects, this work suggests that future efforts incorporate the larger scale attributes in evaluation of potential covariates of bird abundance within the study area. Also, with greater sampling effort, the presence of interactions between watershed, or possibly sub-regions, and habitat characters could be explored.

The assumption that a simplistic relationship exists between population densities and higher quality habitat has little empirical support, and has thus been heavily disputed (Van Horne 1983, Marzluff and Ewing 2001, Smallwood 2001, Maurer 1986). Source-sink theory (Pulliam 1988) supports this argument because non-viable populations can be maintained by immigration from outside source populations. Understanding habitat quality, therefore, requires the use of population measures outside of simple inventory data and should include the use of demographic data (Van Horne 1983, Marzluff and Ewing 2001, Smallwood 2001). Demographic measures such as reproductive success, productivity, survivorship, recruitment and dispersal can all aid in a better understanding of ecosystem function and health.

Despite these previously described limitations of bird habitat models (Rotenberry 1986), and the uncertainty associated with the use of indices in developing habitat preference models, (Van Horne 1983, Wiens and Rotenberry 1981, Knopf and Samson 1994), this study finds evidence for fine scale habitat 
associations of several riparian songbirds in part by addressing potential limitations. 


\section{LIST OF REFERENCES}

Alldredge, M.W., T.R. Simons, and K.H. Pollock. 2007. Factors affecting aural detections of songbirds. Ecological Applications 17:948-955.

Askins, R.A. 2002. Restoring North America's birds: lessons from landscape ecology. Yale University Press, New Haven.

Bent, A.C. 1949. Life histories of north American Thrushes, Kinglets and their allies. U.S. Nat. Mus. Bull. 196.

Bureau of Land Management (BLM). 1998. Birds as indicators of riparian vegetation condition in the western U.S. Bureau of Land Management, Partners in Flight, Boise, Idaho. BLM/ID/PT-98/004+6635. Jamestown, ND: Northern Prairie Wildlife Research Center Online. http://www.npwrc.usgs.gov/resource/birds/ripveg/index.htm

Burnham, K. P., and D. R. Anderson. 2002. Model selection and multimodel inference: a practical information-theoretic approach. 2nd Edition. Springer-Verlag, New York, New York, USA. 488 pp.

Carlisle, J.D., S.L Stock, G.S. Kaltenecker and D.L. Swanson. 2004. Habitat associations, relative abundance, and species richness of autumn landbird migrants in southwestern Idaho. The Condor 106:549-566.

Chase, M.K., and G.R. Geupel. 2005. The use of avian focal species for conservation planning in California. Third International Partners in Flight Conference. GTR. PSW-191. Stinson Beach, CA.

Cogswell, H. L. 1962. Operation recovery begun in California's Central Valley.Western Bird Bander 37:5254.

Cooper, D.S. 2004. Important Bird Areas of California. Audubon California. 286 pp. Available (online) at:

http://iba.audubon.org/iba/statelndex.do?state=US-CA .

California Wilderness Coalition (CWC). 2002. A Guide to Wildlands Conservation in Central Coast Region of California. Technical Document. Davis, CA.

Davis, F. W., D. M. Stoms, A. D. Hollander, K. A. Thomas, P. A. Stine, D. Odion, M. I. Borchert, J. H. Thorne, M. V. Gray, R. E. Walker, K. Warner, and J. Graae. 1998. The California gap analysis project: final report. University of California, Santa Barbara, CA. 
Dawson, W. L. 1923. The Birds of California: Vol. I. South Moulton Co., San Francisco, CA.

Dawdy, D. R. 1989. Feasibility of mapping riparian forests under natural conditions in California. Pp. 63-68 in Proceedings of the California Riparian Systems Conference. GTR PSW-110, Davis, CA.

DeSante, D. F. and T. L. George. 1994. Population trends in the landbirds of western North America. Pp. 173-190 in J. R. Jehl, Jr. and N. K. Johnson (eds.). A century of avifaunal change in western North America. Studies in Avian Biology No. 15: 173-190.

DeSante, D.F., and Rosenberg, D.K. 1998. What do we need to monitor in order to manage landbirds? In: J. Marzluff and R. Sallabanks (Eds.), Avian Conservation: Research and Management, pp. 93-106. Island Press, Washington, DC.

Dobkin, D. S. 1994. Conservation and management of Neotropical migrant landbirds in the Northern Rockies and Great Plains. University of Idaho Press, Moscow.

Donovan, T. M., C. J. Beardmore, D. N. Bonter, J. D. Brawn, R. J. Cooper, J. A. Fitzgerald, R. Ford, S. A. Gauthreaux, T. L. George, W. C. Hunter, T. E. Martin,J. Price, K. V. Rosenberg, P. D. Vickery, and T. B. Wigley. 2002. Priority research needs for the conservation

Dunn, J.L. and K.L. Garrett. 1997. A field guide to warblers of North America. Houghton Mifflin Company, Boston MA.

Faber, P.M. (ed.). 2003. Proceedings of the Riparian Habitat and Floodplains Conference. RHJV, Sacramento, CA. Rich, T.D. 2002. Using breeding landbirds in the assessment of western riparian systems. Wildlife Society Bulletin 30:1128-1139.

Farmer, C. 1999. The density and distribution of Brown-headed Cowbirds: The central coastal California enigma. Studies in Avian Biology: 18:62-67.

Farnsworth, G.L., K.H. Pollock, J.D. Nichols, T.R. Simons, J.E. Hines, and J.R. Sauer. 2002. A removal model for estimating detection probabilities from point-count surveys. The Auk: 119:414-425.

Flannery, M. E., S. L. Guers, T. Gardali, N. Nur, and G. R. Geupel. 2004. Landbird migration at the Salton Sea: the importance of desert riparian habitat. Studies in Avian Biology: 27:106-115. 
Gaines, D. F. 1974. The nesting riparian avifauna of the Sacramento Valley, California and the status of the Yellow-billed Cuckoo. MS Thesis. University of California. Davis, CA.

Gaines, D. F. 1977. The valley riparian forests of California: their importance to bird populations. In A. Sands (ed.). Riparian forests in California: their ecology and conservation. Institute of Ecology Publication 15. University of California, Davis, CA.

Gardali, T., A.L. Holmes, S.L. Small, N. Nur, G.R. Geupel, and G. Golet. 2006. Abundance Patterns of Landbirds in Restored and Remnant Riparian Forests on the Sacramento River, California, U.S.A. Restoration Ecology: 14(3): 391-403.

Garrett, K. and J. Dunn. 1981. Birds of southern California: status and distribution. Los Angeles Audubon Society, Los Angeles, California.

Grinnell, J., and A.H. Miller. 1944. The distribution of birds of California. Pacific Coast Avifauna 27.

Heath, S. K. and G. Ballard. 2003. Patterns of breeding songbird diversity and occurrence in riparian habitats of the eastern Sierra Nevada.

Proceedings of the riparian habitat and floodplains conference (P. Faber, Editor). Riparian Habitat Joint Venture, Sacramento, California, USA.

Hosmer, D.W., and Lemeshow, S. 2000. Applied Logistic Regression. New York: Wiley.

Hubert, J.O. 1906. A list of birds collected between Monterey and San Simeon in the coast range of California. The Condor: Vol. 8(5):122-130.

Humple, D. L. AND G. R. Geupel. 2002. Autumn populations of birds in riparian habitat of California's Central Valley. Western Birds 33:34 -50

Jeffres, C., Opperman, J.J., and Moyle, P.B. 2008. Ephemeral floodplain habitats provide best growth conditions for juvenile Chinook salmon in a California river. Environmental Biology of Fishes. Vol. 83(4):449-458.

Johnson, D.H. 2008. In defense of indices: The case of bird surveys. The Journal of Wildlife Management.72(4):857-868.

Katibah, E. F. 1984. A brief history of riparian forests in the Central Valley of California. In R. E. Warner and K. M. Hendrix (eds). California Riparian Systems: Ecology, Conservation, and Productive Management. University of California Press Ltd. London, England. 
Knopf, F. L., R. R. Johnson, T. Rich, F. B. Samson, and R. C. Szaro. 1988. Conservation of riparian ecosystems in the United States. Wilson Bulletin 100:272-284.

Knopf, F.L. and F.B. Samson. 1994. Scale perspectives on avian diversity in western riparian ecosystems. Conservation Biology 8(3):669-676.

Kondolf, G.M., R. Kattelmann, M. Embury, and D.C. Erman. 1996. Status of riparian habitat. Sierra Nevada Ecosystem Project: Final report to Congress, vol. II. Assessments and scientific basis for management options. Davis: University of California, Centers for Water and Wildland Resources, 1996.

Land Conservancy San Luis Obispo (LCSLO). 2010. Restoration Field Guide. A user friendly field guide for restoration techniques in riparian habitats. Technical Document. San Luis Obispo, CA.

Lindgren, E. 2006 Nest survivorship in a California Warbling Vireo population: low all around.Paper presented at The Western Section of the Wildlife Society Annual Meeting.

Lindgren, E., M.A. Truan, R.E. Melcer Jr., and A. Engilis, Jr.. 2006. Putah Creek Terrestrial Wildlife Monitoring Plan. Mus. of Wildlife and Fish Biol. Occasional Papers No.2. University of California, Davis, CA.

Lowther, P. E. 2000. Pacific-slope Flycatcher (Empidonax difficilis) and Cordilleran Flycatcher (Empidonax occidentalis). In The Birds of North America, No. 556 (A. Poole and F. Gill, eds.). The Birds of North America, Inc., Philadelphia, PA.

Manley, P. and C. Davidson. 1993. A risk analysis of Neotropical migrant birds in California, U.S. Forest Service report, Region 5. San Francisco, CA.

Marantz, C. 1988. Birds of San Luis Obispo County, California: their status and distribution. Master's Thesis. California Polytechnic State University, San Luis Obispo. 184 pp.

Martin and Geupel. 1993. Nest-monitoring Plots: Methods for locating nests and monitoring success. Journal of field Ornithology:64(4):507-519.

Marzluff, J. M., and K. Ewing. 2001. Restoration of fragmented landscapes for the conservation of birds: A general framework and specific recommendations for urbanizing landscapes. Restoration Ecology: 9:280292. 
Mauer, B. A. 1986. Predicting habitat quality for grassland birds using density-habitat correlations. Journal of Wildlife Management 50:556-566.

Meents, J.K., J. Rice, B.W. Anderson, and R.D. Ohmart. 1983. Nonlinear relationships between birds and vegetation. Ecology 64: 1022-27.

Melcer Jr., R. E., E. Lindgren, M. A. Truan, and A. Engilis, Jr. 2006. Yolo Bypass Riparian Bird and Wildlife Monitoring Program, 2005 Progress Report. Museum of Wildlife and Fish Bioliology. University of California, Davis, CA.

Miller, A. H. 1951. An analysis of the distribution of the birds of California. University of California Pub. Zool. 50:531-643.

Morrison, M. L., I. C. Timossi, and K. A. With. 1987. Development and testing of linear regression models predicting bird-habitat relationships. Journal of Wildlife Management 51:247-253.

Morro Bay National Estuary Program (MBNEP). 2000. Comprehensive Conservation and Management Plan. Technical Document. Morro Bay, CA.

Nur, N., G. Ballard, and G. R. Geupel. 2008. Regional analysis of riparian bird species response to vegetation and local habitat features. The Wilson Journal of Ornithology. 120(4):840-855, 2008.

Nur, N., S. L. Jones, and G. R. Geupel. 1999. A statistical guide to data analysis of avian monitoring programs. U.S. Department of the Interior, Fish and Wildlife Service, BTP-R6001-1999, Washington, D.C.

Oneil, A.S., and Rotenberry, J.T. 2009. Scale-dependent habitat relations of birds in riparian corridors in an urbanizing landscape. Landscape and Urban Planning. 92(3-4):264-275.

Pulliam, H. R. 1988. Sources, sinks and population regulation. American Naturalist 132: 652-661.

Purcell, K. 2006. Abundance and productivity of Warbling Vireos across an elevational gradient in the Sierra Nevada. The Condor. 108(2): 315-325

R Development Core Team. 2010. R: A language and environment for statistical computing, reference index version 2.11.1. R Foundation for Statistical Computing, Vienna, Austria. ISBN 3-900051-07-0, URL http://www.R-project.org. 
Ralph, C. J. 1998. A comparison of timing, content, and monitoring methods of landbird migration in the Pacific States. Paper presented at the North American Ornithological Conference, April 1998. St. Louis, MO.

Ralph, C.J., G.R. Geupel, P. Pyle, T.E. Martin, and D.F. DeSante. 1993 . Field Methods for Monitoring Landbirds. USDA Forest Service Gen. Tech. Rep.PBSD-GTR-144. Albany, CA.

Ralph, C.J., S. Droege, and J.R. Sauer. 1995. Monitoring bird populations by point counts. USDA, Forest Service, General Technical Report PSWGTR-149. Pacific Southwest Fores and Range Experiment Station, Albany, California, USA.

Rich, T. 1998. Guide for assessing the occurrence of breeding birds in western riparian systems. Draft Report, Fish, Wildlife and Forests Group, Bureau of Land Management. Boise, ID.

Riparian Habitat Joint Venture (RHJV). 2004. The riparian bird conservation plan: a strategy for reversing the decline of riparian associated birds in California. California Partners in Flight. http://www.prbo.org/calpif/pdfs/riparian_v-2.pdf

Robertson, B. A. and R. L. Hutto. 2007. Is selectively harvested forest an ecological trap for Olive-sided flycatchers. Condor 109:109-121.

Rotenberry, J.T. 1986. Habitat relationships of shrub-steppe birds: even "good" models cannot predict the future, p. 217-221. In J. Verner, M. L. Morrison, and C. J. Ralph [eds.], Wildlife 2000: modeling habitat relationships of terrestrial vertebrates. Univ. Wisconsin Press, Madison, WI.

Saab, V. 1999. Importance of spatial scale to habitat use by breeding birds in riparian forests: a Hierarchical analysis. Ecological Applications 9(1):135-151

Sauer, J. R., J. E. Hines, J. E. Fallon, K. L. Pardieck, D. J. Ziolkowski, Jr., and W. A. Link. 2011. The North American Breeding Bird Survey, Results and Analysis 1966 - 2009. Version 3.23.2011 USGS Patuxent Wildlife Research Center, Laurel, MD

Seavy, N.E., Viers, J.H., Wood, J.K. 2009. Riparian bird response to vegetation structure: a multiscale analysis using LiDAR measurements of canopy height. Ecological Applications. Vol. 19(7):1848-1857.

Shuford, W.D., and Gardali, T., editors. 2008. California Bird Species of Special Concern: A ranked assessment of species, subspecies, and 
distinct populations of bird of immediate conservation concern in California. Studies of Western Birds 1. Western Field Ornithologists, Camarillo, California, and California Department of Fish and Game, Sacramento.

Simons, T.R., M.W. Alldredge, and K.H. Pollock. 2007. Experimental analysis of the auditory detection process on avian point counts. The Auk 124: 986-999.

Simons, T. R., K. H. Pollock, J. M. Wettroth, M. W. Alldredge, K. Pacifici, and J. Brewster. 2009 Sources of measurement error, misclassification error, and bias in auditory avian point count data. pp. 237-254 in D.L. Thomson et al. (eds.), Modeling Demographic Processes in Marked Populations, Environmental and Ecological Statistics 3, Springer Science and Business Media.

Small, A. 1994. California birds: their status and distribution. Ibis Publishing Company, Vista, CA. 342 pp.

Smallwood, K.S. 2001. Linking habitat restoration to meaningful units of animal demography. Restoration ecology 9:253-261.

Smith. J.I., M.D. Reynolds and G. LeBuhn. 2005. Warbling Vireo reproductive success and nest-site characteristics in the northern Sierra Nevada, California. Journal of Field Ornithology. 76(4): 383-389

Strusis-Timmer, M. 2009. Habitat associations and nest survival of Yellow Warblers in California. Master's Theses. Paper 3682. http://scholarworks.sjsu.edu/etd_theses/3682

Sibley, C. G. 1940. The Warbling Vireo of the Cape District of lower California. Condor 42: 255-258.

The Nature Conservancy of California (TNC). 2006. Central Coast Ecoregional Plan Update. Technical Document. San Francisco, CA.

Unitt, P. 1984. The Birds of San Diego County. San Diego Society of Natural History, Memoir 13.

Van Horne, B. 1983. Density as a misleading indicator of habitat quality. Journal of Wildlife Management. 47:893-901.

Verner, J., and A.S. Boss [EDS.]. 1980. California wildlife and their habitats: western Sierra Nevada. Gen. Tech. Rep. PSW-37. Fresno, CA. U.S. Dept. Agric., For. Serv., Pac. Southwest For. And Range Exp. Sta. 
White, G. C., D. R. Anderson, K. P. Burnham, And D. L. Otis. 1982. Capture-recapture and removal methods for sampling closed populations. Los Alamos National Laboratory Publication LA- 8787-NERP, Los Alamos, New Mexico.

Whitlock, M. and Schluter, D. 2009. The analysis of biological data. Roberts and Company Publisher, Colorado, USA.

Wiens, J.A. and J.T. Rotenberry. 1981. Censusing and the evaluation of avian habitat occupancy. Studies in Avian Biology No. 6:522-532.

Young, J.S. 1996. Non-linear bird-habitat relationships in manage forest of Swan Valley, Montana. M.S. Thesis, University of Montana. 


\section{APPENDICES}

Appendix A. Geographic coordinates and maps for avian and vegetation sampling plots.

TABLE A1. Summary of site, site acronym, point count name, and GPS coordinates for all sampling plots. Data were recorded in UTM, Zone 10 S,WGS84.

\begin{tabular}{|c|c|c|c|c|c|c|c|c|}
\hline \multicolumn{3}{|c|}{ Arroyo Grande (AG) } & \multicolumn{3}{|c|}{ Reservoir Canyon (RC) } & \multicolumn{3}{|c|}{ Santa Rosa Creek (SR) cont. } \\
\hline AG01 & 726328 & 3895764 & RC01 & 715611 & 3907918 & SR08 & 673524 & 3937123 \\
\hline AG02 & 726070 & 3895796 & $\mathrm{RCO} 2$ & 715821 & 3907680 & SR09 & 673920 & 3937099 \\
\hline AG03 & 725935 & 3895519 & $\mathrm{RCO3}$ & 715994 & 3907489 & SR10 & 673980 & 3937353 \\
\hline AG04 & 725737 & 3895329 & RCO4 & 716291 & 3907380 & SR11 & 674226 & 3937451 \\
\hline AG05 & 725478 & 3895255 & RC05 & 716528 & 3907295 & SR12 & 674483 & 3937588 \\
\hline AG06 & 725209 & 3895224 & RC06 & 716666 & 3907080 & SR13 & 674664 & 3937771 \\
\hline \multicolumn{3}{|c|}{ Cerro Alto (CA) } & RCO7 & 716859 & 3906928 & SR14 & 674900 & 3937560 \\
\hline CA01 & 704119 & 3922825 & RC08 & 717050 & 3906756 & SR15 & 675169 & 3937633 \\
\hline CA02 & 704342 & 3922681 & \multicolumn{3}{|c|}{ Santa Rita (SC) } & SR16 & 675357 & 3937898 \\
\hline CA03 & 704503 & 3922461 & SC01 & 701231 & 3933037 & SR17 & 675605 & 3937994 \\
\hline CA04 & 704773 & 3922403 & $\mathrm{SCO} 2$ & 700981 & 3933288 & SR18 & 675877 & 3938010 \\
\hline CA05 & 705038 & 3922421 & $\mathrm{SCO} 3$ & 700744 & 3933348 & SR19 & 676132 & 3937969 \\
\hline CA06 & 703873 & 3922780 & $\mathrm{SCO} 4$ & 700490 & 3933347 & SR20 & 676380 & 3937926 \\
\hline CA07 & 704093 & 3923078 & SCO5 & 700248 & 3933533 & SR21 & 676649 & 3937864 \\
\hline CA08 & 703990 & 3923497 & SC06 & 700014 & 3933529 & $\mathrm{SR} 22$ & 676920 & 3937934 \\
\hline CA09 & 703931 & 3923739 & SCO7 & 699753 & 3933726 & SR23 & 677240 & 3937972 \\
\hline \multicolumn{3}{|c|}{ Coon Creek (CC) } & $\mathrm{SC08}$ & 699516 & 3933630 & SR24 & 677393 & 3938193 \\
\hline CCO1 & 692202 & 3903452 & SC09 & 699271 & 3933565 & SR25 & 677654 & 3938308 \\
\hline $\mathrm{CCO} 2$ & 692410 & 3903307 & SC10 & 699245 & 3933327 & & & \\
\hline $\mathrm{CCO3}$ & 692595 & 3903138 & SC11 & 699426 & 3933094 & & & \\
\hline $\mathrm{CCO} 4$ & 692787 & 3903297 & SC12 & 699129 & 3932510 & & & \\
\hline CCO5 & 693049 & 3903252 & SC13 & 699342 & 3932376 & & & \\
\hline $\mathrm{CCO6}$ & 693286 & 3903168 & SC14 & 699294 & 3932048 & & & \\
\hline $\mathrm{CCO}$ & 693514 & 3903069 & \multicolumn{6}{|c|}{ San Luis Obispo Creek (SL) } \\
\hline $\mathrm{CCO} 8$ & 693749 & 3902982 & SL01 & 709153 & 3895958 & & & \\
\hline CCO9 & 693881 & 3902770 & SL02 & 708891 & 3895903 & & & \\
\hline CC10 & 694081 & 3902619 & SL03 & 708720 & 3896085 & & & \\
\hline CC11 & 694337 & 3902594 & SL04 & 708500 & 3896216 & & & \\
\hline \multicolumn{3}{|c|}{ Pismo Creek (PC) } & SL05 & 708239 & 3896214 & & & \\
\hline PC01 & 716792 & 3895426 & SL06 & 707977 & 3896201 & & & \\
\hline PCO2 & 716661 & 3895225 & SL07 & 707741 & 3896287 & & & \\
\hline PCO3 & 716643 & 3894977 & SL08 & 707483 & 3896327 & & & \\
\hline PCO4 & 716468 & 3894766 & SL09 & 707153 & 3896303 & & & \\
\hline PC05 & 716338 & 3894606 & \multicolumn{3}{|c|}{ Santa Rosa Creek (SR) } & & & \\
\hline PC06 & 716238 & 3894380 & SR01 & 671948 & 3937660 & & & \\
\hline PC07 & 716057 & 3894206 & SR02 & 672116 & 3937485 & & & \\
\hline PC08 & 715975 & 3893982 & SR04 & 672400 & 3937094 & & & \\
\hline PCO9 & 715771 & 3893841 & SR05 & 672787 & 3936972 & & & \\
\hline PC10 & 715588 & 3893662 & SR06 & 673039 & 3936952 & & & \\
\hline PC11 & 715706 & 3893386 & SR07 & 673283 & 3937041 & & & \\
\hline
\end{tabular}


FIGURE A1. Map of the Arroyo Grande field site including point count locations and vegetation sampling plots over CA Department of Fish and Game 2009 summer aerial imagery in natural color.

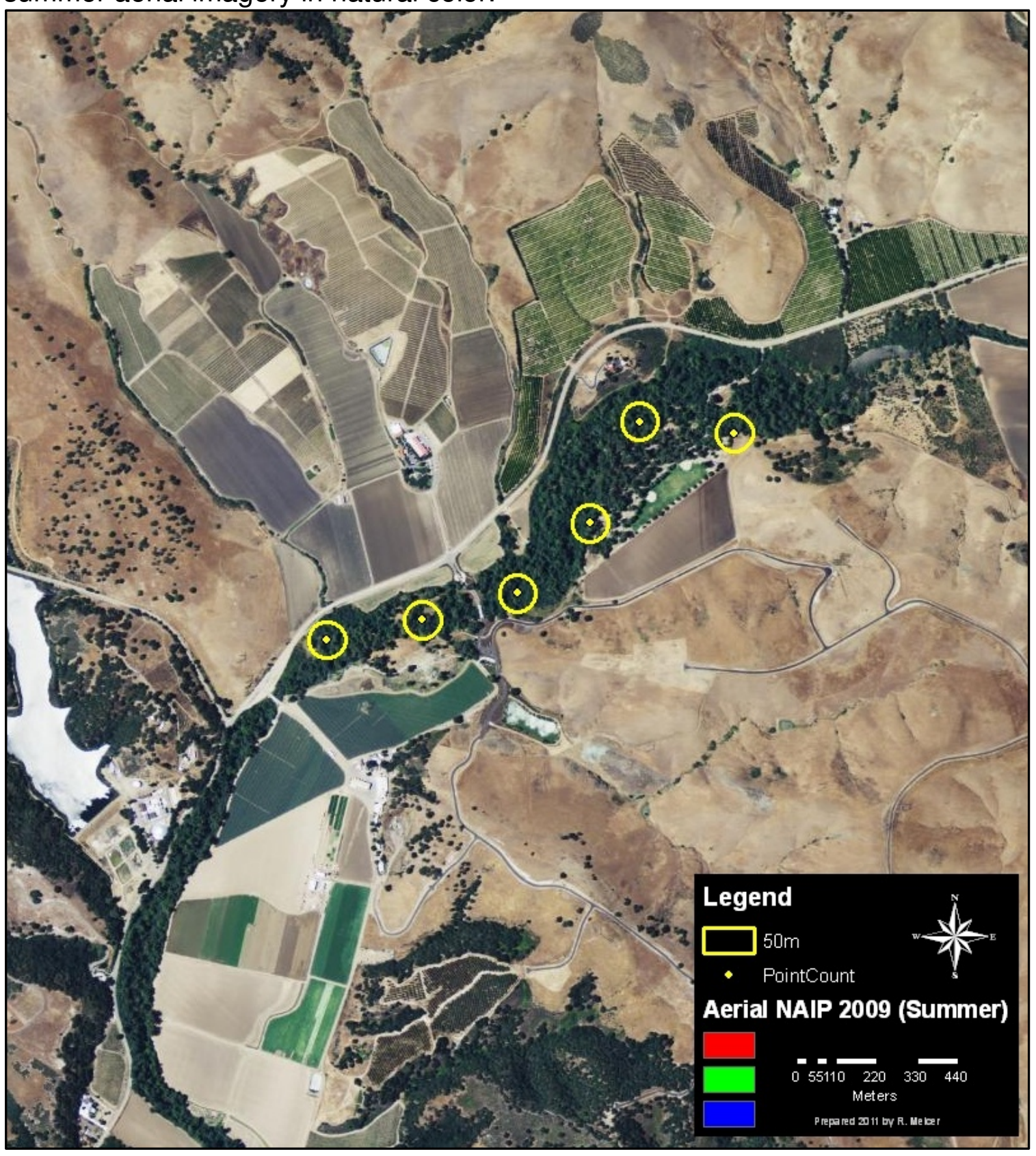


FIGURE A2. Map of the Cerro Alto field site including point count locations and vegetation sampling plots over CA Department of Fish and Game 2009 summer aerial imagery in natural color.

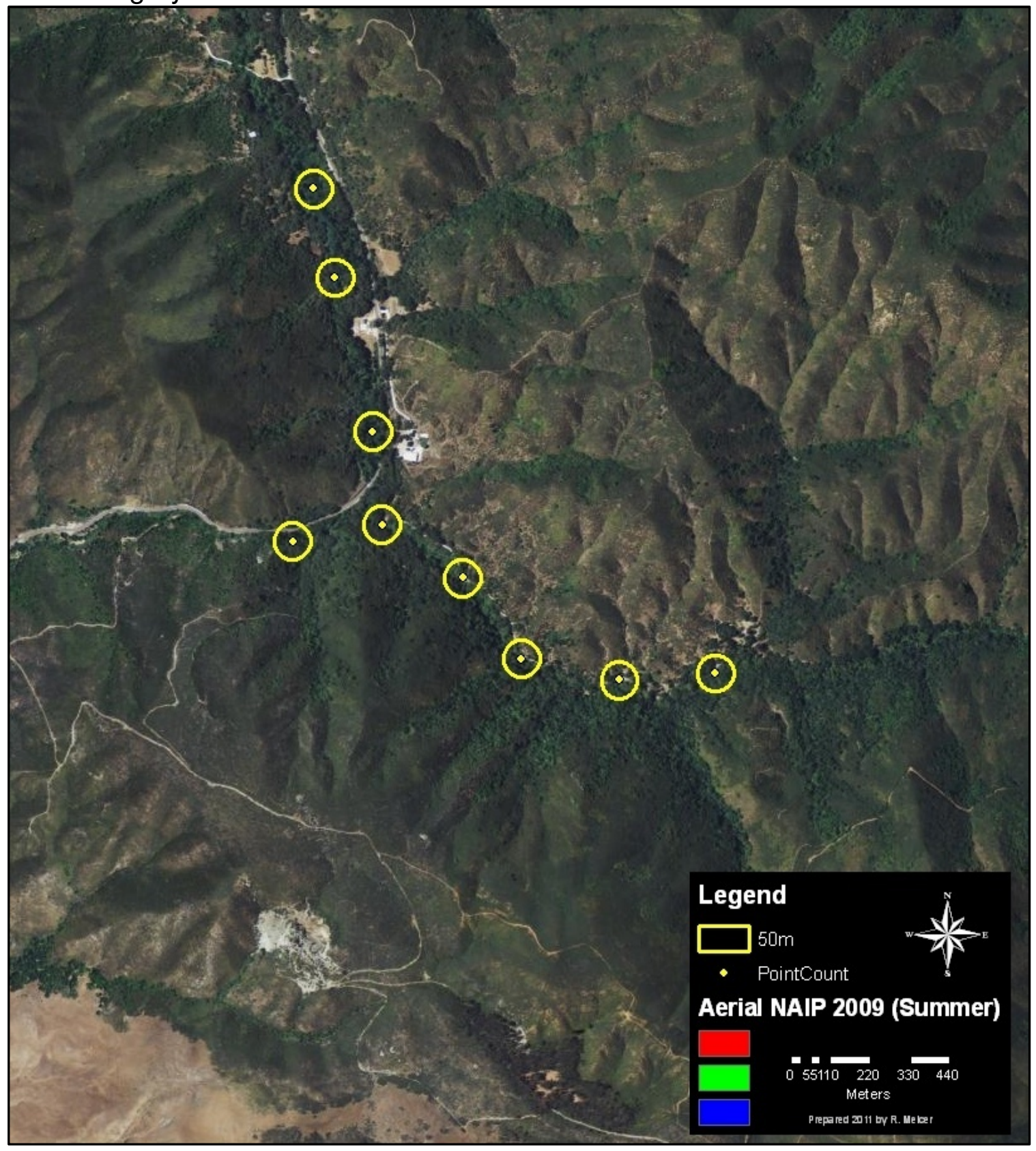


FIGURE A3. Map of the Coon Creek field site including point count locations and vegetation sampling plots over CA Department of Fish and Game 2009 summer aerial imagery in natural color.

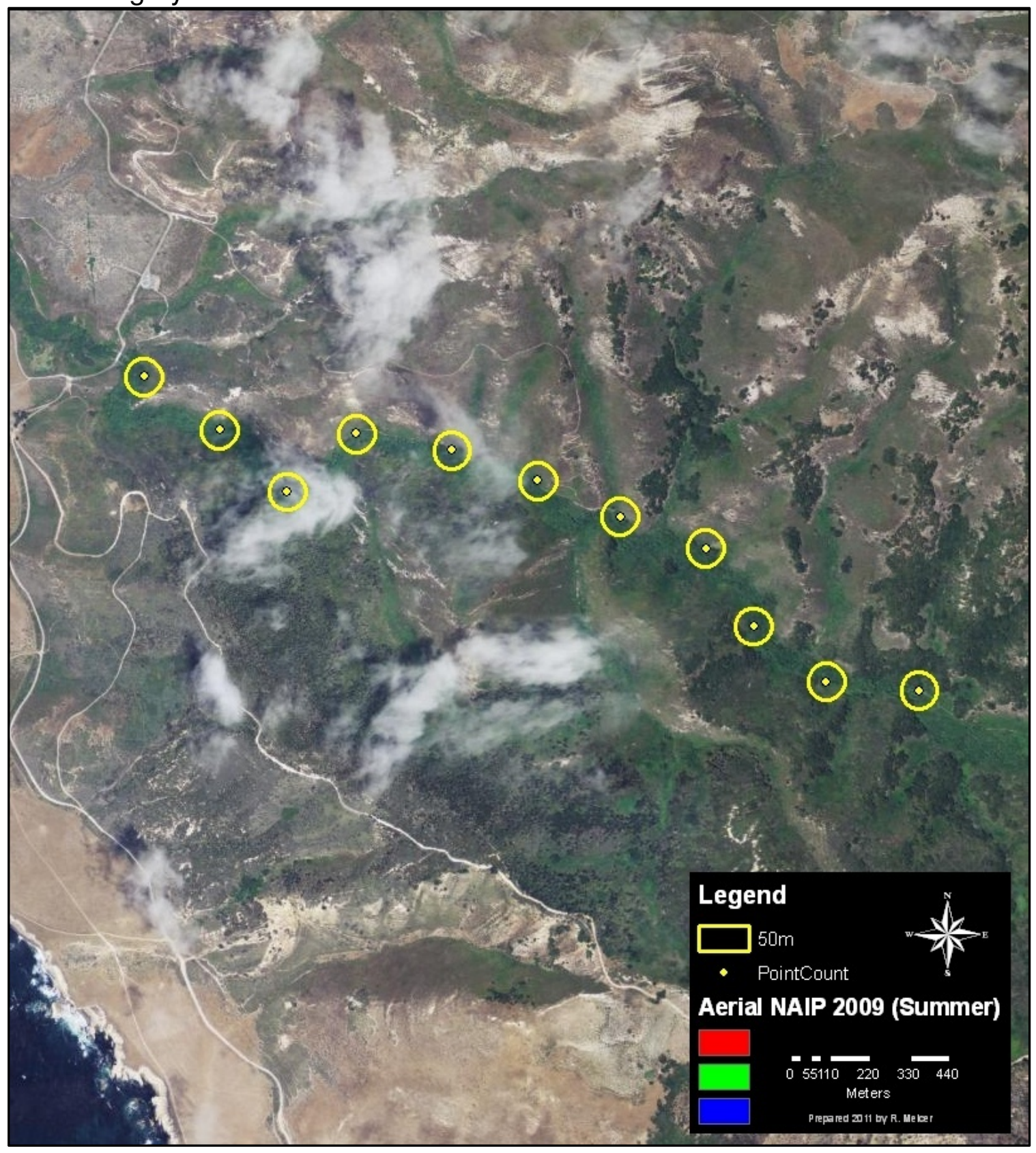


FIGURE A4. Map of the Pismo Creek field site including point count locations and vegetation sampling plots over CA Department of Fish and Game 2009 summer aerial imagery in natural color.

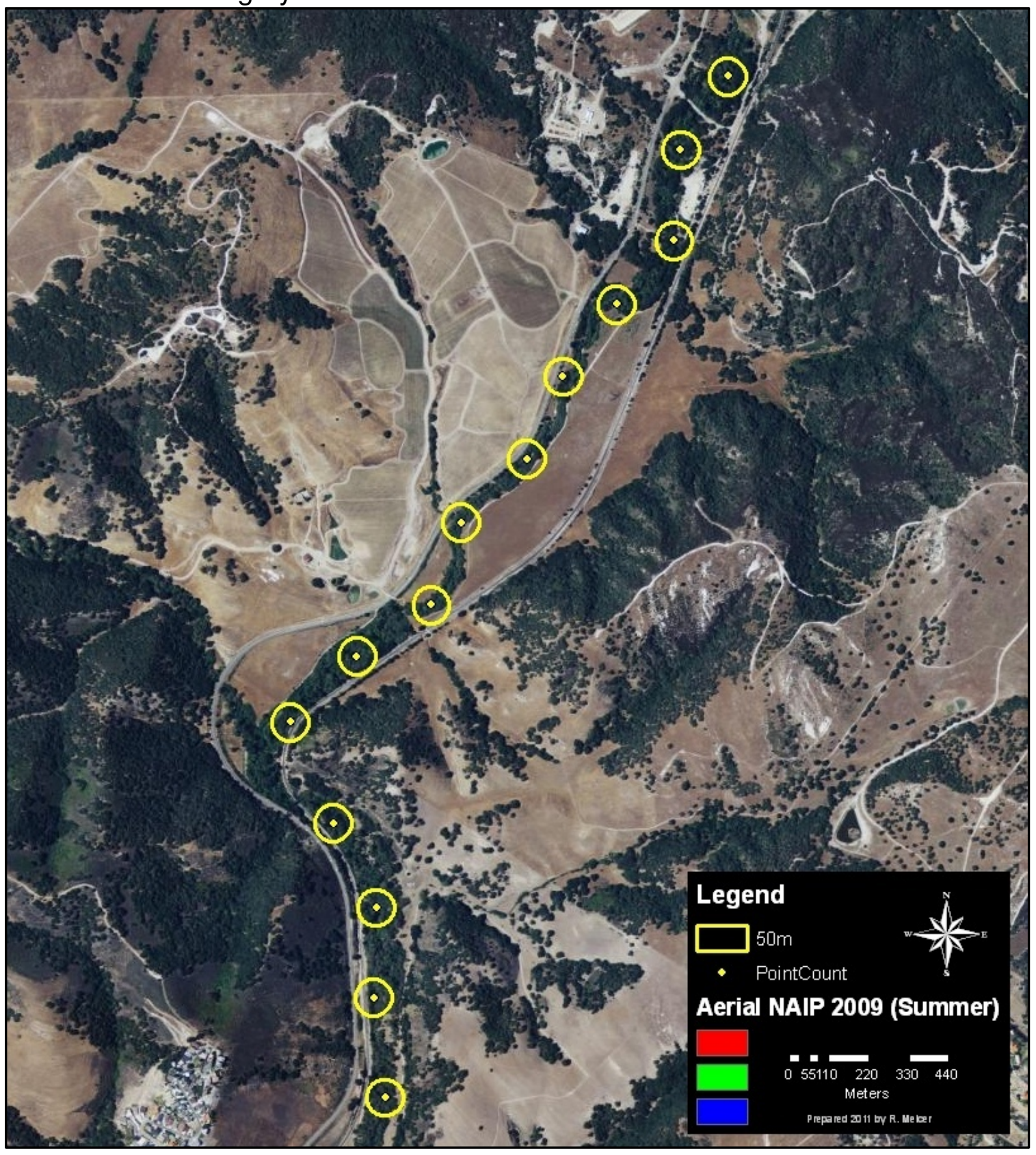


FIGURE A5. Map of the Reservoir Canyon field site including point count locations and vegetation sampling plots over CA Department of Fish and Game 2009 summer aerial imagery in natural color.

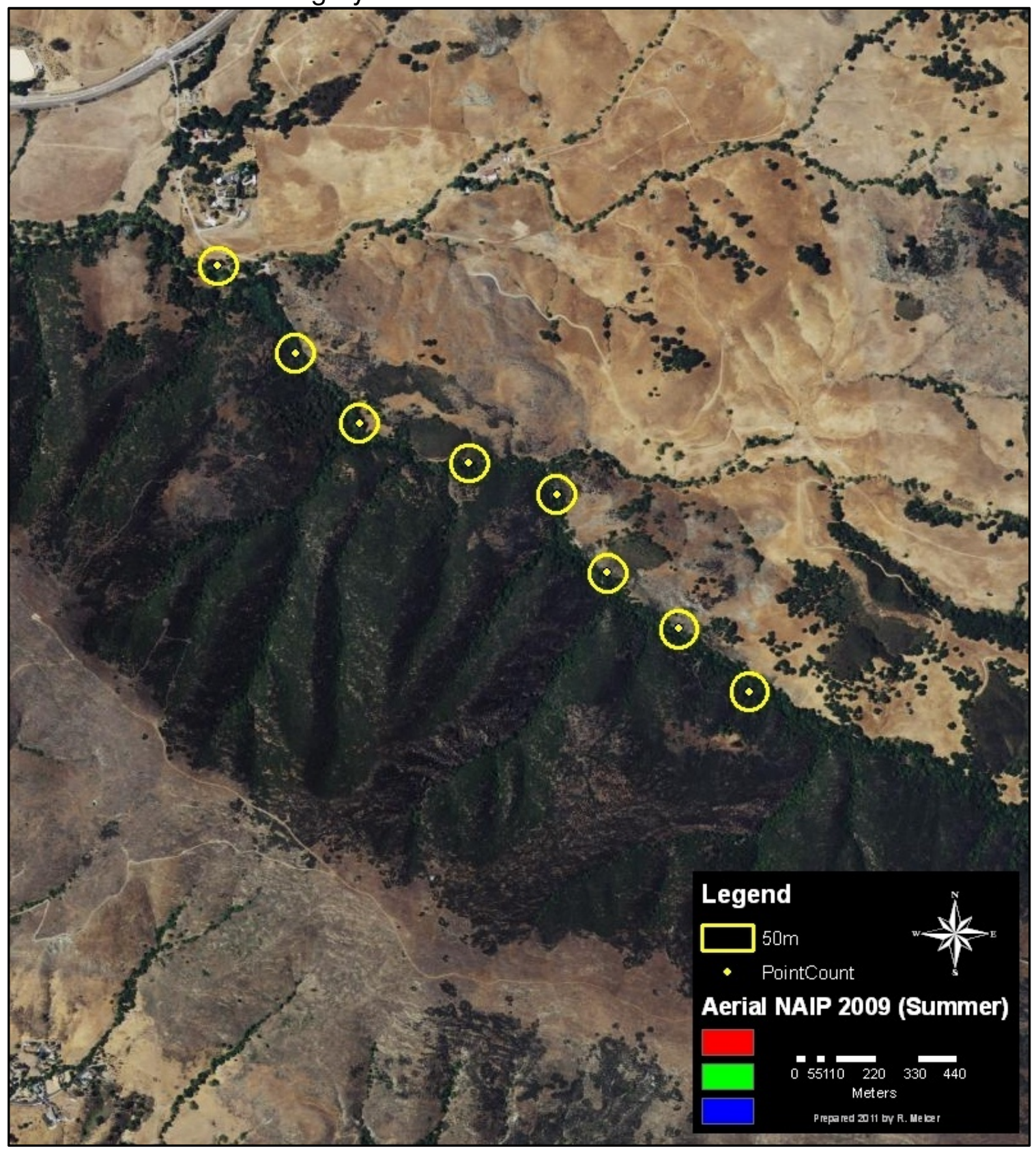


FIGURE A6. Map of the Santa Rita field site including point count locations and vegetation sampling plots over CA Department of Fish and Game 2009 summer aerial imagery in natural color.

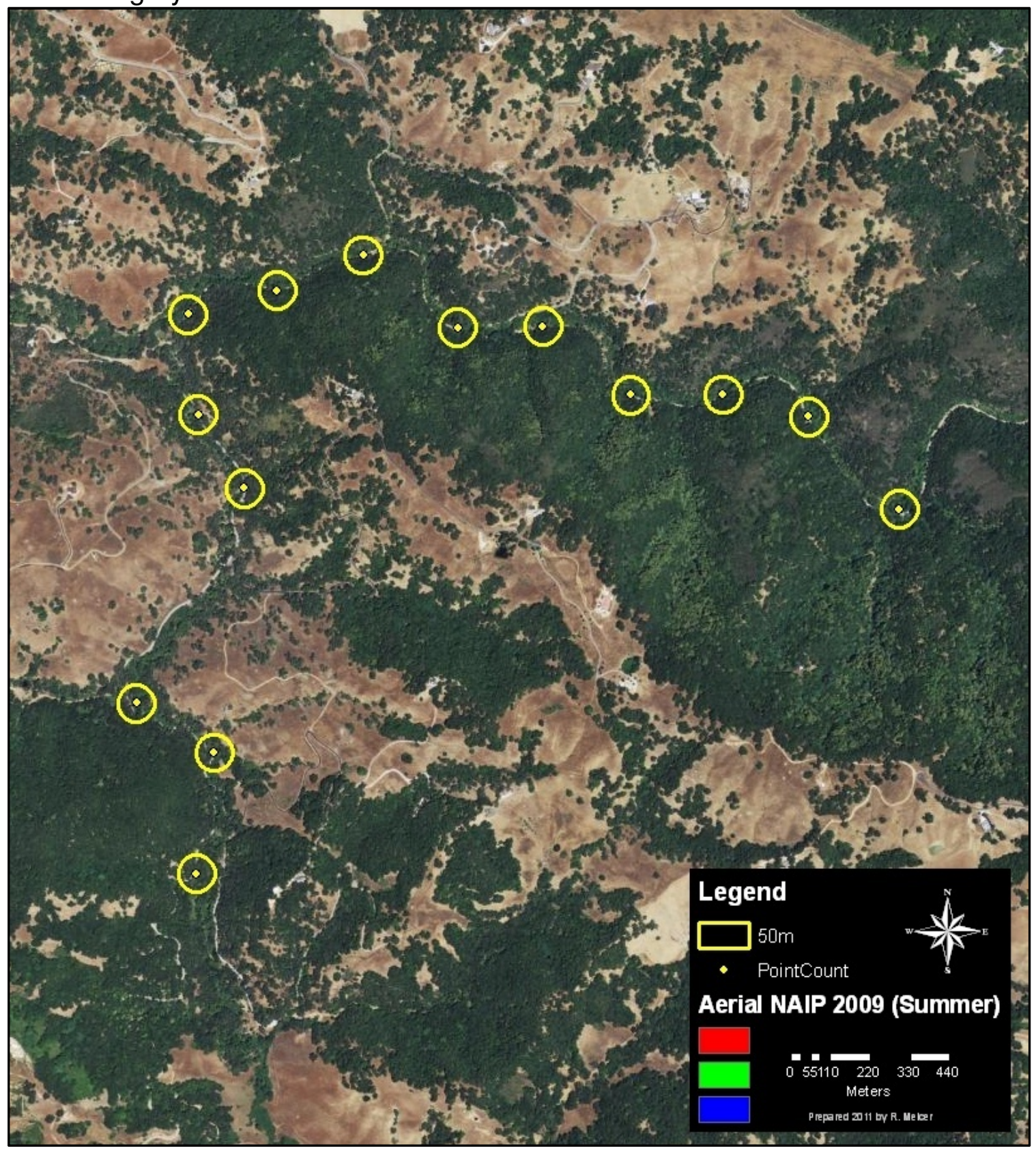


FIGURE A7. Map of the western segment of the Santa Rosa field site including point count locations and vegetation sampling plots over CA Department of Fish and Game 2009 summer aerial imagery in natural color.

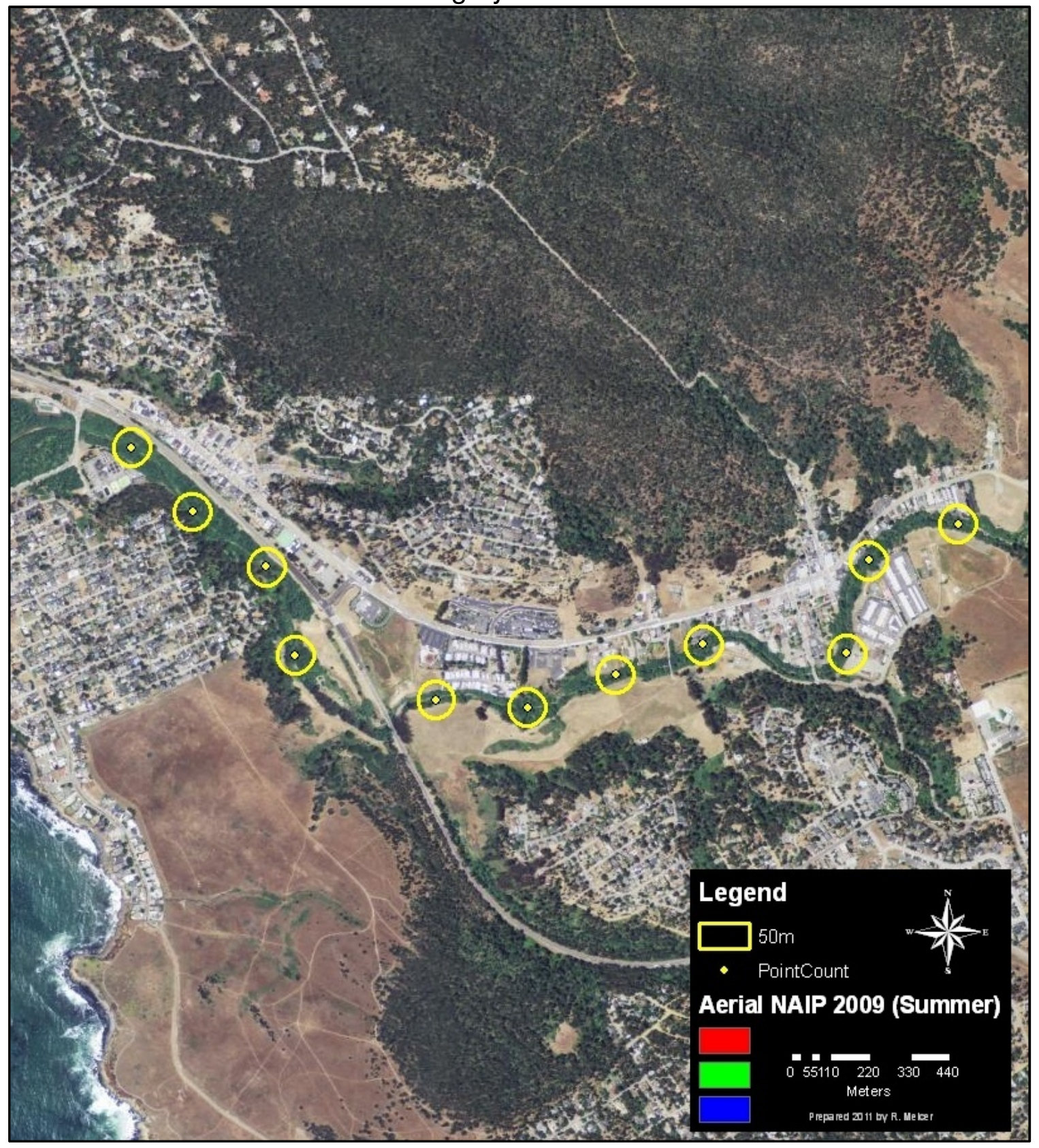


FIGURE A8. Map of the eastern segment of the Santa Rosa field site including point count locations and vegetation sampling plots over CA Department of Fish and Game 2009 summer aerial imagery in natural color.

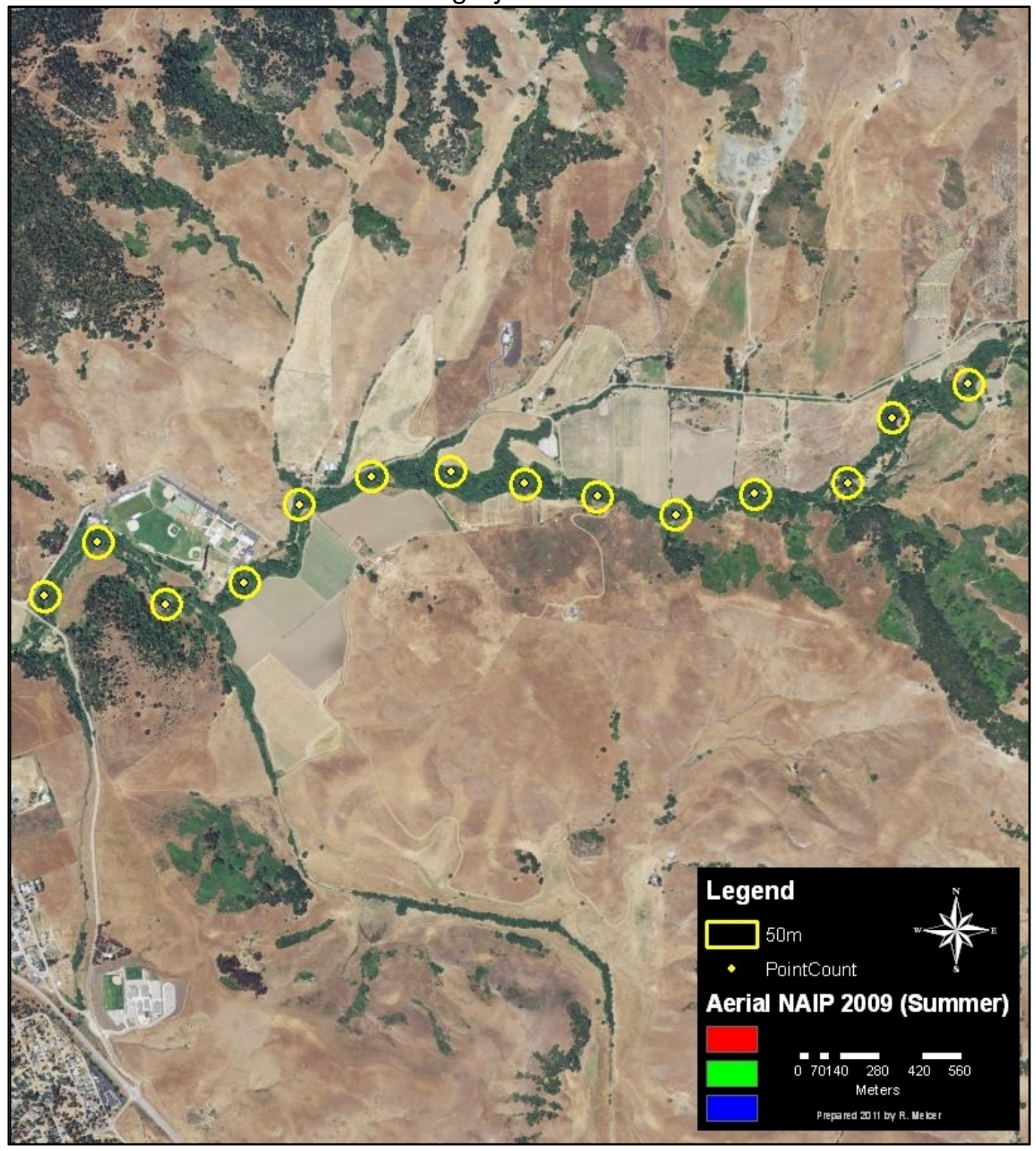


FIGURE A9. Map of the San Luis Obispo Creek field site including point count locations and vegetation sampling plots over CA Department of Fish and Game 2009 summer aerial imagery in natural color.

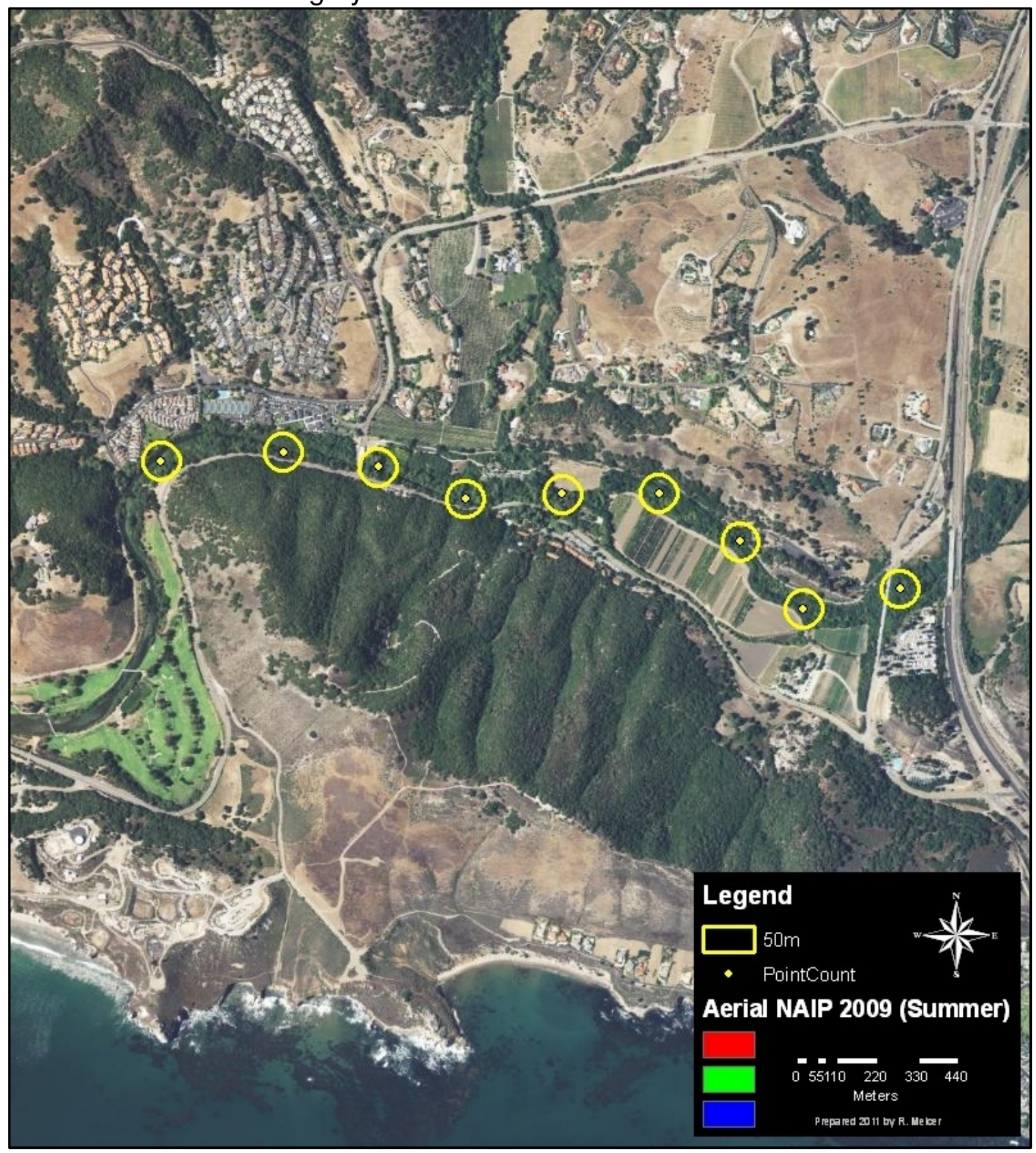


Appendix B. Tests of assumptions for linear models.

TABLE B1. Pearson's Correlation Coefficents and corresponding p-values for habitat variables. The null hypothesis for this test is that there is no linear correlation between the habitat variables being evaluated ( $x$ vs. $y$ ). Correlations were assessed at critical value of 0.60 , and pairwise comparison's that exceeded $r=0.60$ are shown in bold.

\begin{tabular}{|c|c|c|c|c|c|c|c|c|c|c|c|c|c|c|c|c|c|c|}
\hline & $\begin{array}{c}\text { CORRIDOR } \\
\text { WIDTH }\end{array}$ & EEVATION & $\begin{array}{c}\% \text { COVER } \\
\text { FORB }\end{array}$ & $\begin{array}{l}\text { \% COVER } \\
\text { GRASS }\end{array}$ & $\begin{array}{l}\text { \% COVER } \\
\text { SHRUB }\end{array}$ & $\begin{array}{l}\text { \% COVER } \\
\text { CANOPY }\end{array}$ & TREE HEGGH & DBH INDEX & $\begin{array}{l}\text { TREE SPP } \\
\text { RICHNESS } \\
\end{array}$ & $\begin{array}{l}\text { SHRUB SPP } \\
\text { RICHNESS } \\
\end{array}$ & $\begin{array}{c}\text { \% COVER } \\
\text { BLACKBERRY }\end{array}$ & $\begin{array}{c}\text { \% COVER } \\
\text { POISONOAK } \\
\end{array}$ & $\begin{array}{l}\text { \% COVER } \\
\text { DOGWOOD }\end{array}$ & $\begin{array}{l}\% \text { COVER } \\
\text { BACCHARIS }\end{array}$ & $\begin{array}{l}\% \text { COVER } \\
\text { WLLOW }\end{array}$ & $\begin{array}{l}\% \text { COVER } \\
\text { SYCAMORE }\end{array}$ & $\begin{array}{l}\text { \% COVER } \\
\text { COITTNWOOD }\end{array}$ & 6 COVER OAK \\
\hline EEVATION & $\begin{array}{l}-0.09 \\
0.435\end{array}$ & & & & & & & & & & & & & & & & & \\
\hline$\%$ COVER FORB & $\begin{array}{l}0.05 \\
0.650\end{array}$ & $\begin{array}{l}-0.03 \\
0.785\end{array}$ & & & & & & & & & & & & & & & & \\
\hline$\%$ COVER GRASS & -0.17 & 0.08 & -0.08 & & & & & & & & & & & & & & & \\
\hline \% COVER SHRUB & $\begin{array}{l}0.45 \\
0.10\end{array}$ & $\begin{array}{l}0.520 \\
0.44\end{array}$ & $\begin{array}{l}0.501 \\
-0.27\end{array}$ & -0.17 & & & & & & & & & & & & & & \\
\hline$\%$ COVERCANOPY & $\begin{array}{l}0.426 \\
0.09\end{array}$ & $\begin{array}{l}0.000 \\
0.25\end{array}$ & $\begin{array}{l}0.021 \\
0.05\end{array}$ & $\begin{array}{l}0.150 \\
-0.21\end{array}$ & & & & & & & & & & & & & & \\
\hline \%COVEK CANOPY & 0.449 & 0.033 & 0.660 & 0.083 & 0.183 & & & & & & & & & & & & & \\
\hline TRE HEGHT & $\begin{array}{l}0.23 \\
0.049\end{array}$ & $\begin{array}{l}0.10 \\
0.398\end{array}$ & $\begin{array}{l}0.17 \\
0.45\end{array}$ & $\begin{array}{l}-0.26 \\
0.028\end{array}$ & $\begin{array}{l}-0.06 \\
0.606\end{array}$ & $\begin{array}{l}0.09 \\
0.450\end{array}$ & & & & & & & & & & & & \\
\hline DBH INDEX & $\begin{array}{l}0.34 \\
0.004\end{array}$ & $\begin{array}{l}0.45 \\
0.000\end{array}$ & $\begin{array}{l}0.24 \\
0.043\end{array}$ & $\begin{array}{l}-0.060 \\
0.596\end{array}$ & $\begin{array}{l}-0.000 \\
0.012\end{array}$ & $\begin{array}{l}0.00 \\
0.992\end{array}$ & $\begin{array}{l}0.34 \\
0.003\end{array}$ & & & & & & & & & & & \\
\hline TRE SPP RICHNESS & $\begin{array}{l}0.12 \\
0.085\end{array}$ & $\begin{array}{l}0.56 \\
0.000\end{array}$ & $\begin{array}{l}0.22 \\
0.063\end{array}$ & $\begin{array}{l}-0.25 \\
0.034\end{array}$ & $\begin{array}{l}-0.16 \\
0.180\end{array}$ & $\begin{array}{l}0.20 \\
0.00\end{array}$ & $\begin{array}{l}0.51 \\
0.000\end{array}$ & $\begin{array}{l}0.29 \\
0.015\end{array}$ & & & & & & & & & & \\
\hline SHRUB SPP RIICHNESS & $\begin{array}{l}-0.24 \\
0.042\end{array}$ & $\begin{array}{l}-0.260 \\
0.027\end{array}$ & $\begin{array}{l}-0.003 \\
0.026\end{array}$ & $\begin{array}{l}0.054 \\
0.0077\end{array}$ & $\begin{array}{l}0.180 \\
0.127\end{array}$ & $\begin{array}{l}0.37 \\
0.002\end{array}$ & $\begin{array}{l}-0.002 \\
0.902\end{array}$ & $\begin{array}{l}-0.20 \\
0.092\end{array}$ & $\begin{array}{l}0.20 \\
0.092\end{array}$ & & & & & & & & & \\
\hline \% COVER BLACKBERRY & $\begin{array}{l}0.09 \\
0.462\end{array}$ & $\begin{array}{l}-0.26 \\
0.027\end{array}$ & $\begin{array}{l}0.39 \\
0.001\end{array}$ & $\begin{array}{l}-0.16 \\
0.189\end{array}$ & $\begin{array}{l}-0.05 \\
0.057\end{array}$ & $\begin{array}{l}0.02 \\
0.998\end{array}$ & $\begin{array}{l}0.06 \\
0.649\end{array}$ & $\begin{array}{l}0.31 \\
0.009\end{array}$ & $\begin{array}{l}0.06 \\
0.606\end{array}$ & $\begin{array}{l}-0.33 \\
0.005\end{array}$ & & & & & & & & \\
\hline \% COVER POISON OAK & $\begin{array}{l}0.35 \\
0.002\end{array}$ & $\begin{array}{l}0.34 \\
0.003\end{array}$ & $\begin{array}{l}-0.35 \\
0.002\end{array}$ & $\begin{array}{l}-0.05 \\
0.663\end{array}$ & $\begin{array}{l}0.23 \\
0.047\end{array}$ & $\begin{array}{l}0.19 \\
0.099\end{array}$ & $\begin{array}{l}0.17 \\
0.60\end{array}$ & $\begin{array}{l}0.02 \\
0.839\end{array}$ & $\begin{array}{l}0.20 \\
0.085\end{array}$ & $\begin{array}{l}0.22 \\
0.069\end{array}$ & $\begin{array}{l}-0.17 \\
0.45\end{array}$ & & & & & & & \\
\hline \% COVER DOGWOOD & $\begin{array}{l}0.12 \\
0.334\end{array}$ & $\begin{array}{l}0.43 \\
0.000\end{array}$ & $\begin{array}{l}-0.07 \\
0.581\end{array}$ & $\begin{array}{c}-0.11 \\
0.371\end{array}$ & $\begin{array}{l}0.35 \\
0.003\end{array}$ & $\begin{array}{l}0.27 \\
0.022\end{array}$ & $\begin{array}{l}0.15 \\
0.224\end{array}$ & $\begin{array}{l}-0.15 \\
0.211\end{array}$ & $\begin{array}{l}0.03 \\
0.813\end{array}$ & $\begin{array}{l}0.35 \\
0.003\end{array}$ & $\begin{array}{l}-0.23 \\
0.047\end{array}$ & $\begin{array}{l}0.29 \\
0.012\end{array}$ & & & & & & \\
\hline$\%$ COVER BACCHARIS & -0.23 & $\begin{array}{l}-0.10 \\
0.387\end{array}$ & $\begin{array}{l}0.16 \\
0.173\end{array}$ & $\begin{array}{l}0.29 \\
0.013\end{array}$ & $\begin{array}{l}0.00 \\
0.990\end{array}$ & -0.05 & $\begin{array}{l}-0.08 \\
0.492\end{array}$ & $\begin{array}{l}-0.04 \\
0.769\end{array}$ & $\begin{array}{l}-0.17 \\
0.46\end{array}$ & $\begin{array}{l}0.05 \\
0.069\end{array}$ & $\begin{array}{l}0.10 \\
0.42\end{array}$ & $\begin{array}{l}0.04 \\
0.720\end{array}$ & $\begin{array}{c}-0.04 \\
0.741\end{array}$ & & & & & \\
\hline \% COVER WILLOW & $\begin{array}{l}0.18 \\
0.82\end{array}$ & $\begin{array}{l}-0.48 \\
0.000\end{array}$ & $\begin{array}{l}-0.09 \\
0.446\end{array}$ & $\begin{array}{l}-0.09 \\
0.458\end{array}$ & $\begin{array}{l}0.41 \\
0.000\end{array}$ & $\begin{array}{l}0.16 \\
0.91\end{array}$ & $\begin{array}{r}-0.27 \\
0.021\end{array}$ & $\begin{array}{l}-0.14 \\
0.236\end{array}$ & $\begin{array}{c}-0.37 \\
0.001\end{array}$ & $\begin{array}{l}-0.12 \\
0.337\end{array}$ & $\begin{array}{l}0.23 \\
0.052\end{array}$ & $\begin{array}{l}-0.02 \\
0.884\end{array}$ & $\begin{array}{l}0.09 \\
0.461\end{array}$ & $\begin{array}{l}0.15 \\
0.198\end{array}$ & & & & \\
\hline$\%$ COVERSYCAMORE & $\begin{array}{l}0.29 \\
0.02\end{array}$ & $\begin{array}{l}0.05 \\
0.677\end{array}$ & $\begin{array}{l}0.19 \\
0.18\end{array}$ & $\begin{array}{l}-0.12 \\
0.300\end{array}$ & $\begin{array}{l}0.01 \\
0.941\end{array}$ & -0.06 & $\begin{array}{l}0.45 \\
0.000\end{array}$ & $\begin{array}{l}0.26 \\
0.025\end{array}$ & $\begin{array}{l}0.34 \\
0.003\end{array}$ & $\begin{array}{l}-0.15 \\
0.222\end{array}$ & $\begin{array}{l}0.16 \\
0.181\end{array}$ & $\begin{array}{l}0.22 \\
0.060\end{array}$ & $\begin{array}{l}0.03 \\
0.795\end{array}$ & $\begin{array}{l}-0.09 \\
0.434\end{array}$ & $\begin{array}{l}-0.12 \\
0.327\end{array}$ & & & \\
\hline \% COVERCOTTONWOOD & $\begin{array}{l}0.012 \\
0.18 \\
0.38\end{array}$ & $\begin{array}{l}-0.03 \\
0.782\end{array}$ & $\begin{array}{l}-0.18 \\
0.243\end{array}$ & $\begin{array}{l}-0.030 \\
0.530\end{array}$ & $\begin{array}{l}0.12 \\
0.326\end{array}$ & $\begin{array}{l}-0.10 \\
0.391\end{array}$ & $\begin{array}{l}0.04 \\
0.731\end{array}$ & $\begin{array}{l}0.05 \\
0.679\end{array}$ & $\begin{array}{l}0.00 \\
0.975\end{array}$ & $\begin{array}{l}-0.09 \\
0.474\end{array}$ & $\begin{array}{l}-0.15 \\
0.27\end{array}$ & $\begin{array}{l}-0.15 \\
0.218\end{array}$ & $\begin{array}{l}0.10 \\
0.46\end{array}$ & $\begin{array}{l}-0.05 \\
0.675\end{array}$ & $\begin{array}{l}0.01 \\
0.939\end{array}$ & $\begin{array}{l}0.26 \\
0.026\end{array}$ & & \\
\hline \% COVER OAK & $\begin{array}{l}-0.12 \\
0.319\end{array}$ & $\begin{array}{l}\mathbf{0 . 7 0} \\
0.000\end{array}$ & $\begin{array}{l}-0.05 \\
0.652\end{array}$ & $\begin{array}{l}0.00 \\
0.970\end{array}$ & $\begin{array}{l}-0.23 \\
0.054\end{array}$ & $\begin{array}{l}0.50 \\
0.000\end{array}$ & $\begin{array}{l}0.19 \\
0.115\end{array}$ & $\begin{array}{l}0.12 \\
0.301\end{array}$ & $\begin{array}{l}0.17 \\
0.154\end{array}$ & $\begin{array}{l}0.39 \\
0.001\end{array}$ & $\begin{array}{l}-0.20 \\
0.100\end{array}$ & $\begin{array}{l}0.18 \\
0.127\end{array}$ & $\begin{array}{c}0.16 \\
0.194\end{array}$ & $\begin{array}{l}-0.08 \\
0.495\end{array}$ & $\begin{array}{l}-0.46 \\
0.000\end{array}$ & $\begin{array}{l}-0.07 \\
0.569\end{array}$ & $\begin{array}{c}-0.09 \\
0.431\end{array}$ & \\
\hline$\%$ COVERBAY & -0.16 & 0.73 & -0.08 & 0.17 & -0.12 & 0.28 & 0.15 & 0.09 & 0.31 & 0.38 & -0.34 & 0.25 & 0.16 & -0.07 & -0.52 & 0.09 & -0.09 & 0.54 \\
\hline
\end{tabular}


TABLE B2. Summary of Levene's test statistics (W) and p-values.

\begin{tabular}{|c|c|c|c|c|c|c|c|c|c|c|c|c|c|c|c|c|}
\hline & \multicolumn{2}{|c|}{ BHGR } & \multicolumn{2}{|c|}{ LNOCWA } & \multicolumn{2}{|c|}{ PSFL } & \multicolumn{2}{|c|}{ SOSP } & \multicolumn{2}{|c|}{ LNSPTO } & \multicolumn{2}{|c|}{ SWTH } & \multicolumn{2}{|c|}{ LNWAVI } & \multicolumn{2}{|c|}{ WIWA } \\
\hline & $w$ & p-value & $w$ & $p$-value & $w$ & $p$-value & $w$ & $p$-value & $w$ & p-value & $w$ & $p$-value & $w$ & $\mathrm{p}$-value & $w$ & $\mathrm{p}$-value \\
\hline Elevation & 1.43 & 0.235 & 1.21 & 0.346 & 1.31 & 0.292 & 3.96 & 0.004 & 0.46 & 0.914 & 1.04 & 0.456 & 1.90 & 0.101 & 1.84 & 0.113 \\
\hline Corridor Width & 8.24 & 0.000 & 0.99 & 0.497 & 11.10 & 0.000 & 2.05 & 0.119 & 4.91 & 0.006 & 5.55 & 0.003 & 1.55 & 0.234 & 3.33 & 0.026 \\
\hline$\%$ Cover Forb & 0.48 & 0.873 & 0.32 & 0.027 & 1.56 & 0.222 & 2.98 & 0.034 & 0.63 & 0.001 & 0.86 & 0.586 & 0.63 & 0.762 & 1.79 & 0.161 \\
\hline \% Cover Shrub & 1.85 & 0.072 & 0.46 & 0.918 & 1.46 & 0.178 & 1.21 & 0.303 & 1.03 & 0.436 & 1.59 & 0.133 & 0.89 & 0.560 & 0.97 & 0.486 \\
\hline$\%$ Cover Canopy & 0.60 & 0.833 & 0.50 & 0.907 & 0.58 & 0.850 & 1.49 & 0.158 & 0.54 & 0.875 & 1.40 & 0.001 & 1.52 & 0.149 & 0.81 & 0.640 \\
\hline Tree Height Index & 1.03 & 0.430 & 0.63 & 0.770 & 1.61 & 0.132 & 0.66 & 0.743 & 1.49 & 0.172 & 1.46 & 0.182 & 0.36 & 0.948 & 0.59 & 0.802 \\
\hline$D B H$ Index & 2.19 & 0.033 & 1.54 & 0.151 & 1.00 & 0.480 & 0.78 & 0.687 & 1.03 & 0.457 & 1.26 & 0.286 & 0.62 & 0.837 & 0.63 & 0.829 \\
\hline Shrub Species Richness & 0.63 & 0.750 & 1.28 & 0.273 & 0.33 & 0.953 & 0.58 & 0.793 & 0.02 & 0.508 & 1.40 & 0.215 & 0.46 & 0.880 & 0.74 & 0.652 \\
\hline \% Cover Blackberry & 0.57 & 0.880 & 0.70 & 0.771 & 1.05 & 0.436 & 1.38 & 0.218 & 0.69 & 0.782 & 0.54 & 0.906 & 0.51 & 0.923 & 1.08 & 0.414 \\
\hline$\%$ Cover Poison Oak & 0.75 & 0.720 & 0.69 & 0.784 & 1.42 & 0.201 & 1.74 & 0.095 & 1.92 & 0.062 & 0.91 & 0.564 & 0.18 & 0.077 & 0.52 & 0.916 \\
\hline$\%$ Cover Dogwood & 0.84 & 0.575 & 1.10 & 0.380 & 0.71 & 0.683 & 1.40 & 0.221 & 0.68 & 0.710 & 1.00 & 0.448 & 0.95 & 0.482 & 0.49 & 0.855 \\
\hline$\%$ Cover Baccharis & - & - & - & - & - & - & - & - & - & - & - & - & - & - & - & - \\
\hline \% Cover Willow & 1.02 & 0.464 & 0.63 & 0.821 & 0.63 & 0.825 & 0.89 & 0.586 & & & 0.67 & 0.792 & 0.35 & 0.982 & 0.76 & 0.706 \\
\hline$\%$ Cover Sycamore & 1.55 & 0.145 & 1.99 & 0.052 & 1.10 & 0.380 & 1.19 & 0.318 & 0.49 & 0.927 & 2.16 & 0.034 & 0.60 & 0.819 & 0.57 & 0.840 \\
\hline$\%$ Cover Cottonwood & 0.58 & 0.768 & 1.70 & 0.133 & 0.85 & 0.554 & 1.19 & 0.328 & 0.86 & 0.581 & 0.55 & 0.790 & 1.85 & 0.100 & 1.23 & 0.305 \\
\hline \% Cover Oak & 1.87 & 0.081 & 0.90 & 0.539 & 0.65 & 0.765 & 0.34 & 0.965 & 0.99 & 0.467 & 1.26 & 0.284 & 0.99 & 0.471 & 1.61 & 0.141 \\
\hline \% Cover Bay & 0.52 & 0.812 & 0.42 & 0.886 & 1.33 & 0.259 & 0.88 & 0.531 & 1.14 & 0.357 & 5.10 & 0.000 & 2.26 & 0.045 & 0.38 & 0.908 \\
\hline
\end{tabular}


FIGURE B1. Scatterplot of \% Cover Oak vs. Elevation, exhibiting linear correlation above the critical value of $r=0.60$.

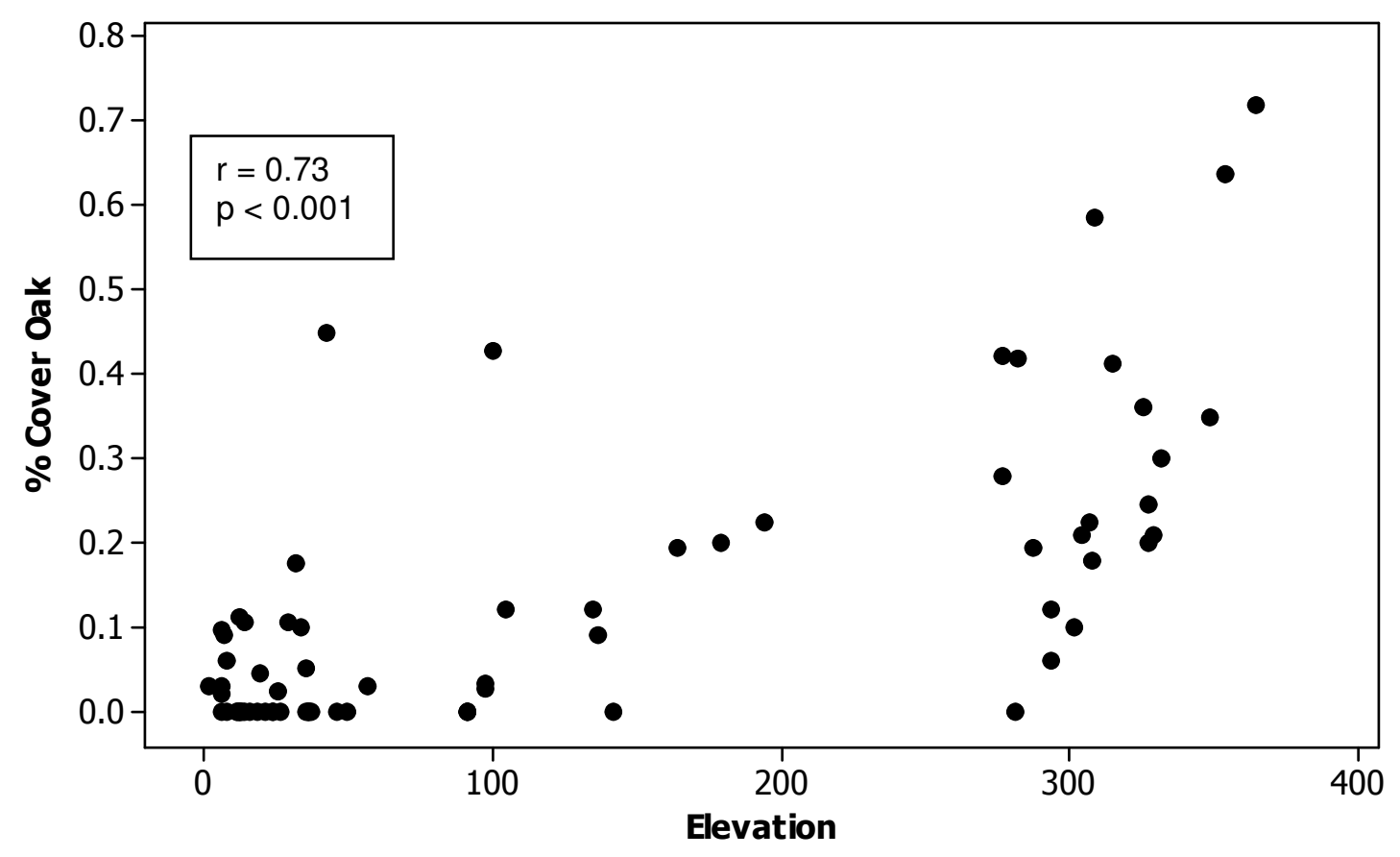

FIGURE B2. Scatterplot of \% Cover Bay vs. Elevation, exhibiting linear correlation above the critical value of $r=0.60$.

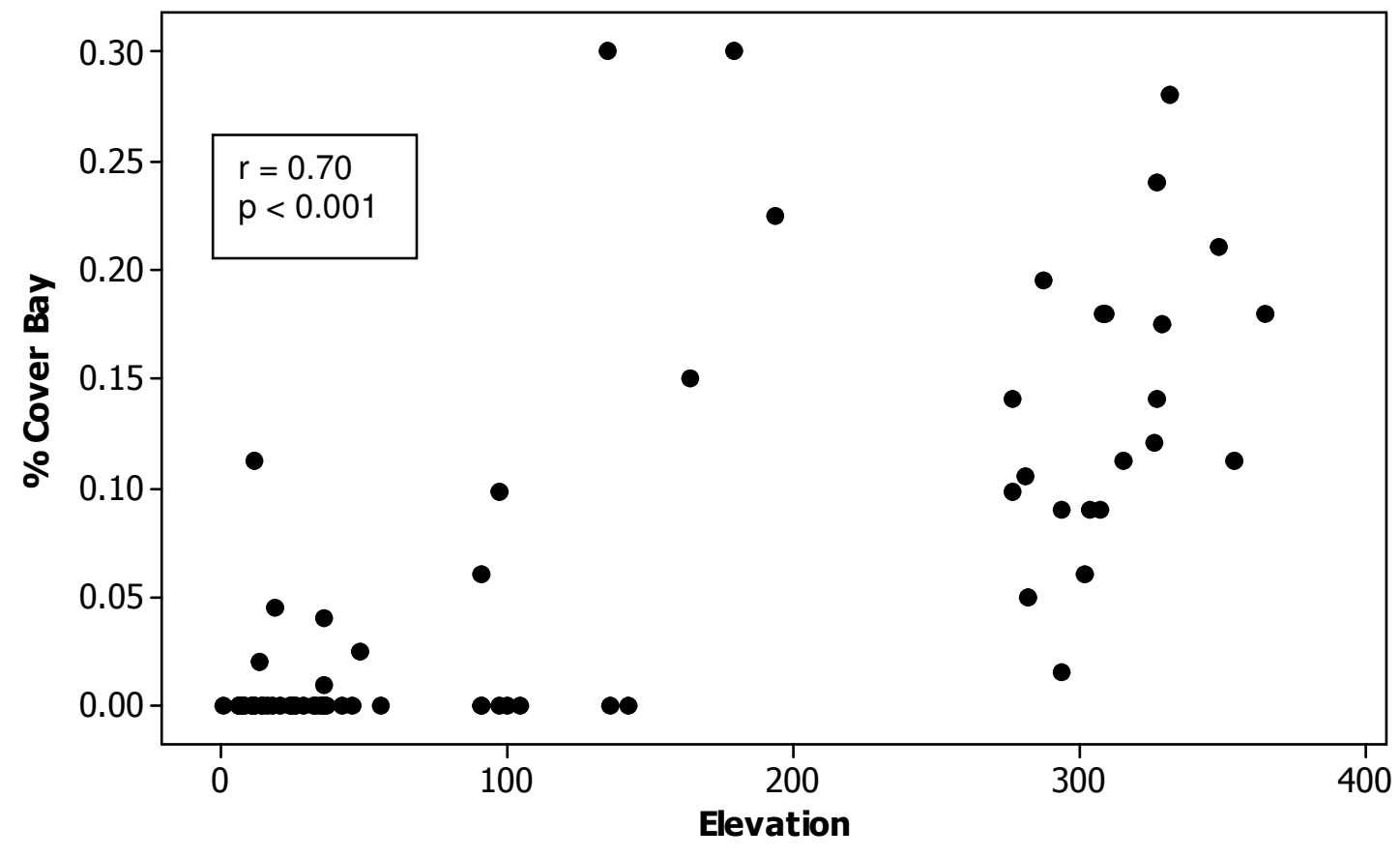


FIGURE B3. Normality plots of residuals and summary statistics for the Ryan Joiner test of normality for the global model of Orange-crowned Warbler.

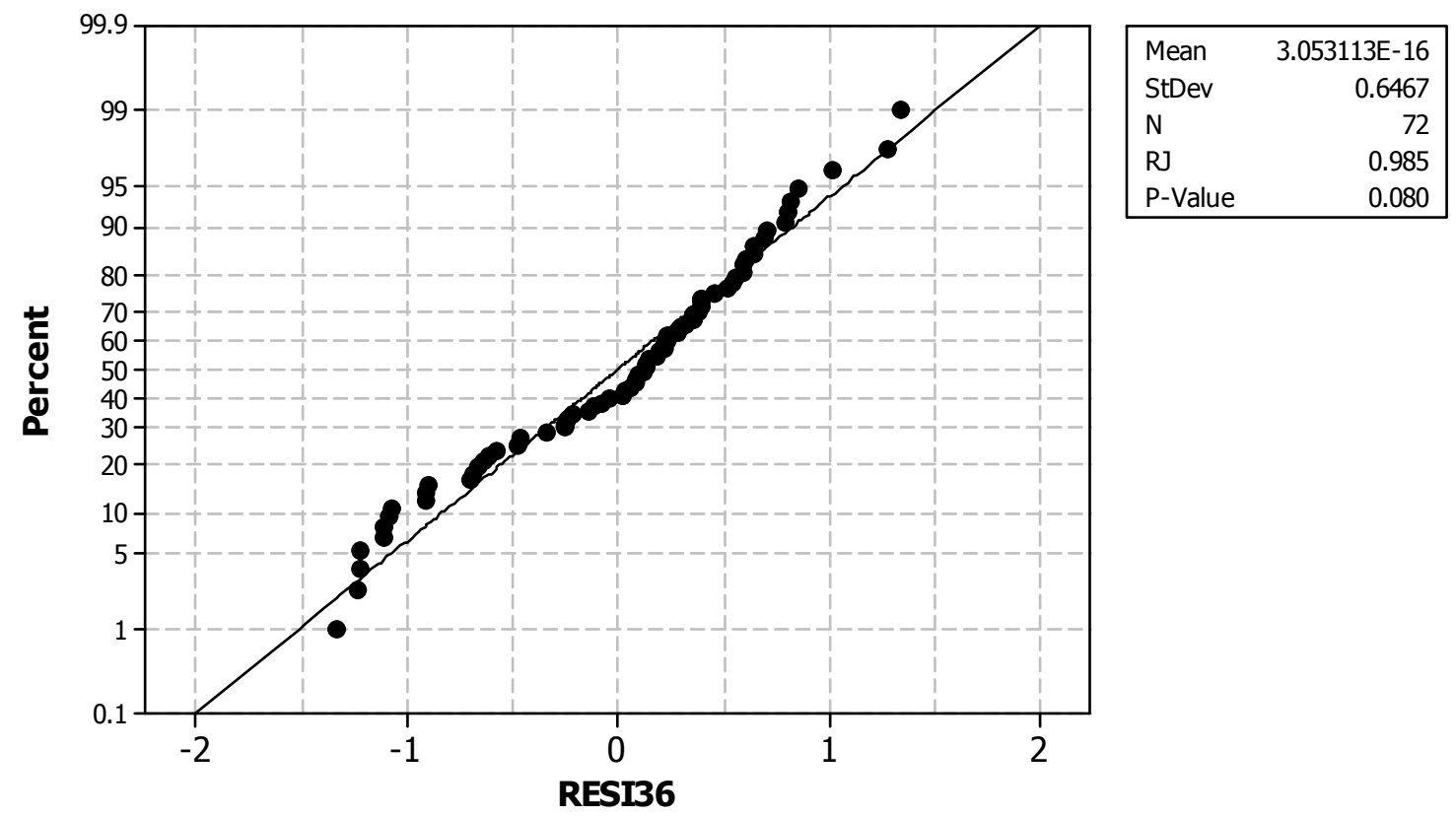

FIGURE B4. Normality plot of residuals and summary statistics for the Ryan Joiner test of normality for the global model of Swainson's Thrush.

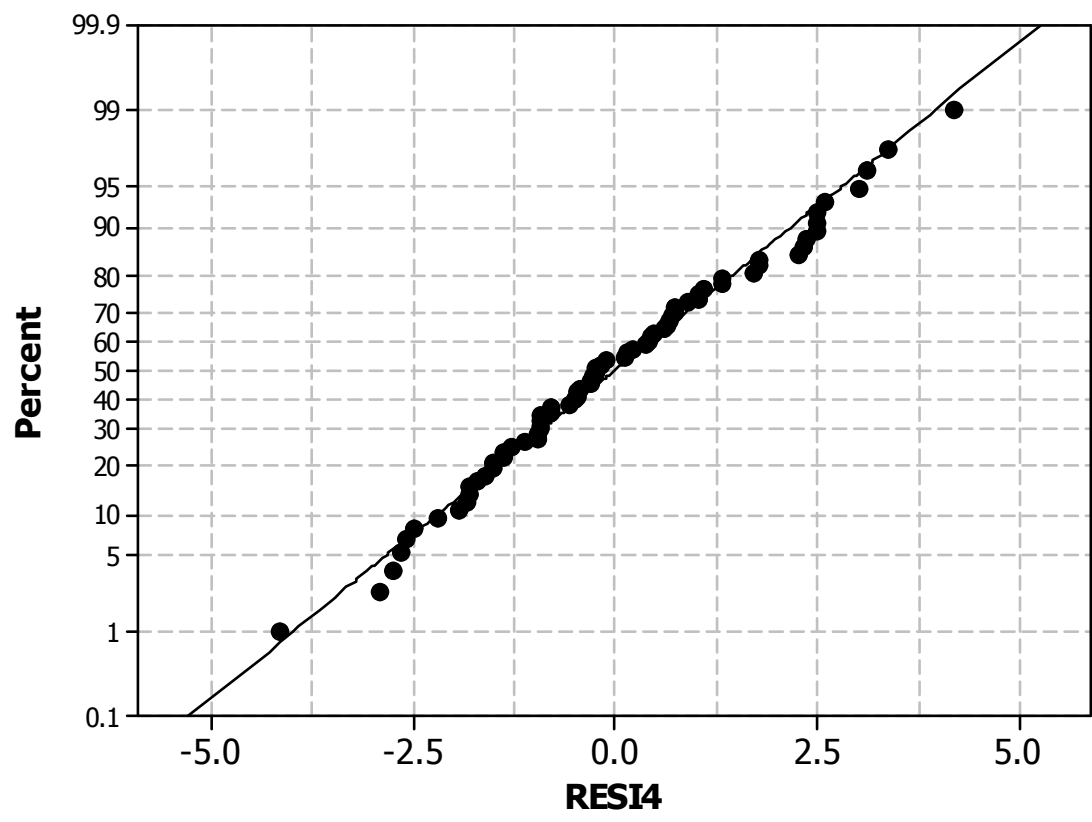

\begin{tabular}{|lr|}
\hline Mean & $-1.57898 \mathrm{E}-15$ \\
StDev & 1.704 \\
$\mathrm{~N}$ & 72 \\
$\mathrm{RJ}$ & 0.995 \\
P-Value & $>0.100$ \\
\hline
\end{tabular}


FIGURE B5. Normality plot of residuals and summary statistics for the Ryan Joiner test of normality for the global model of Song Sparrow.

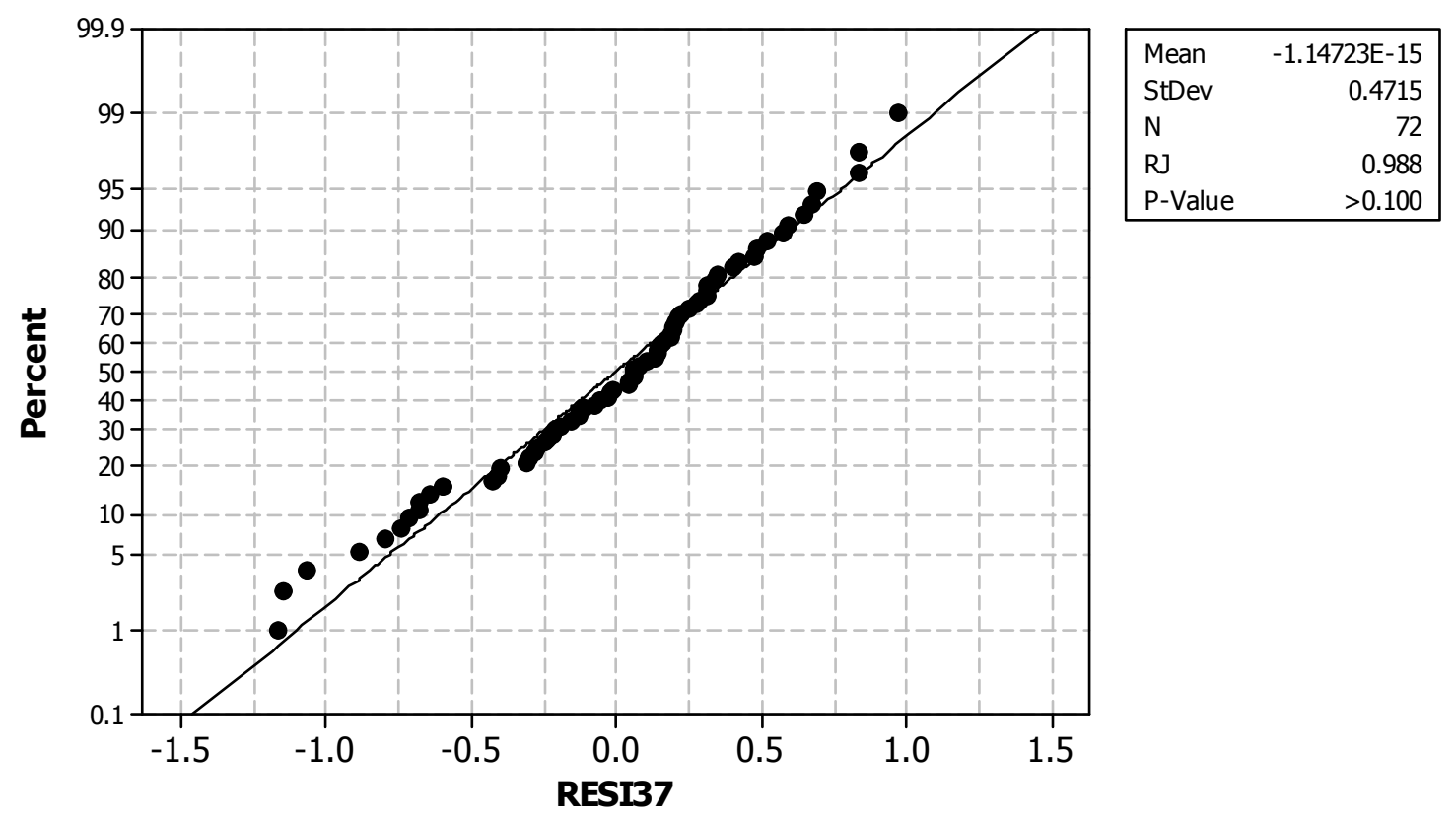

FIGURE B6. Normality plot of residuals and summary statistics for the Ryan Joiner test of normality for the global model of Warbling Vireo.

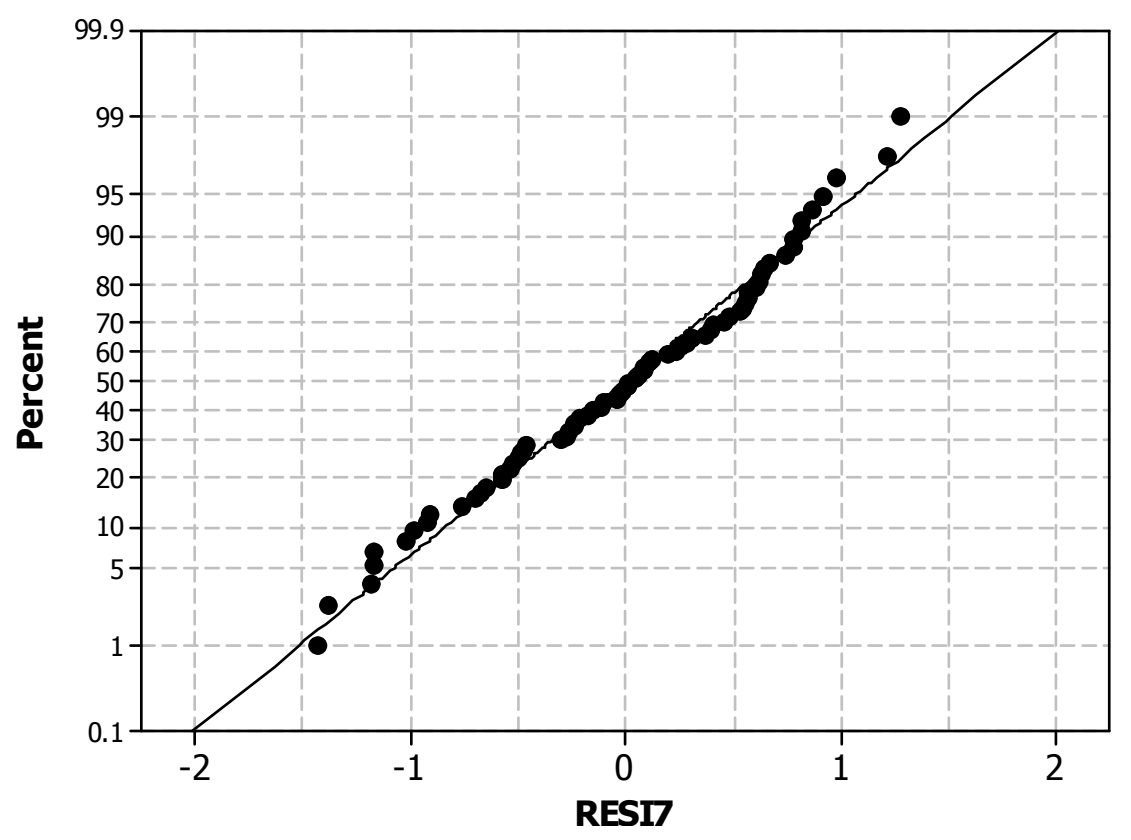

\begin{tabular}{|lr|}
\hline Mean & $-9.09766 \mathrm{E}-17$ \\
StDev & 0.6497 \\
$\mathrm{~N}$ & 72 \\
RJ & 0.992 \\
P-Value & $>0.100$ \\
\hline
\end{tabular}


FIGURE B7. Normality plot of residuals and summary statistics for the Ryan Joiner test of normality for the global model of Wilson's Warbler.

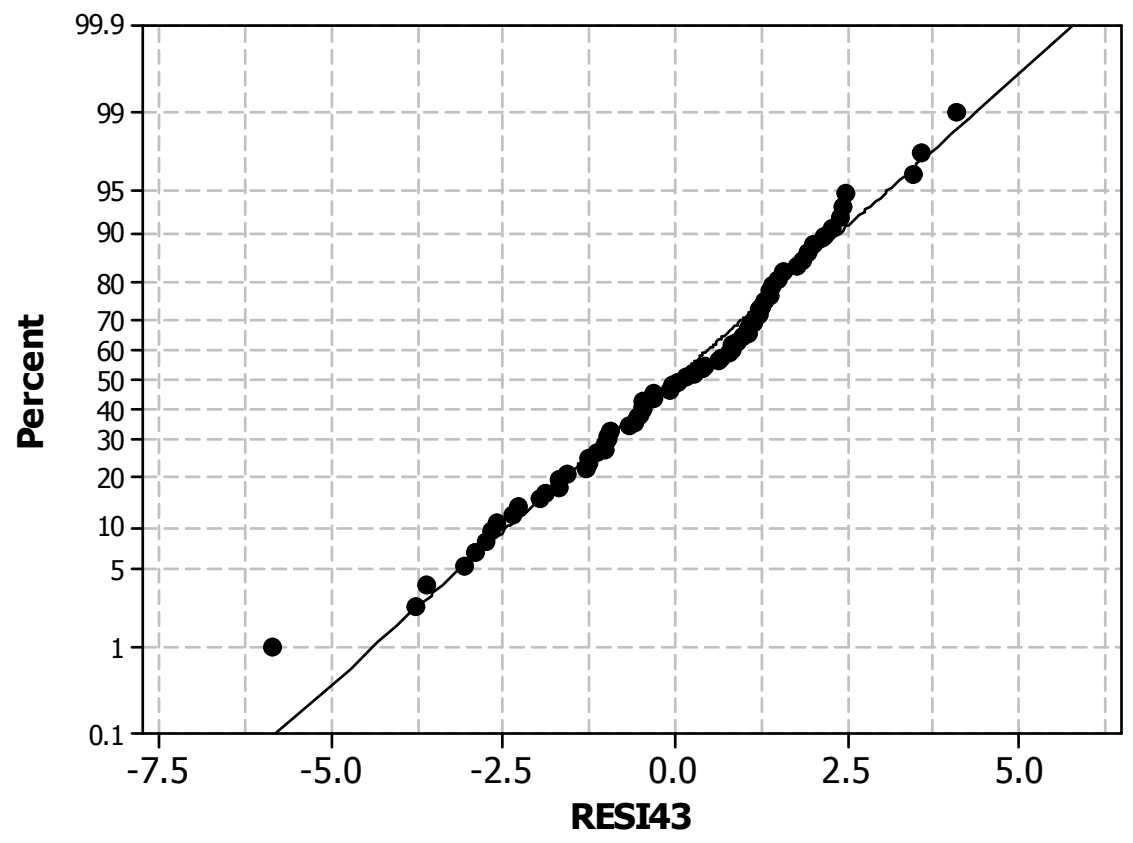

\begin{tabular}{|lr|}
\hline Mean & $-1.57898 \mathrm{E}-15$ \\
StDev & 1.879 \\
$\mathrm{~N}$ & 72 \\
$\mathrm{RJ}$ & 0.991 \\
$\mathrm{P}$-Value & $>0.100$ \\
\hline
\end{tabular}

FIGURE B8. Normality plot of residuals and summary statistics for the Ryan Joiner test of normality for the global model of Black-headed Grosbeak.

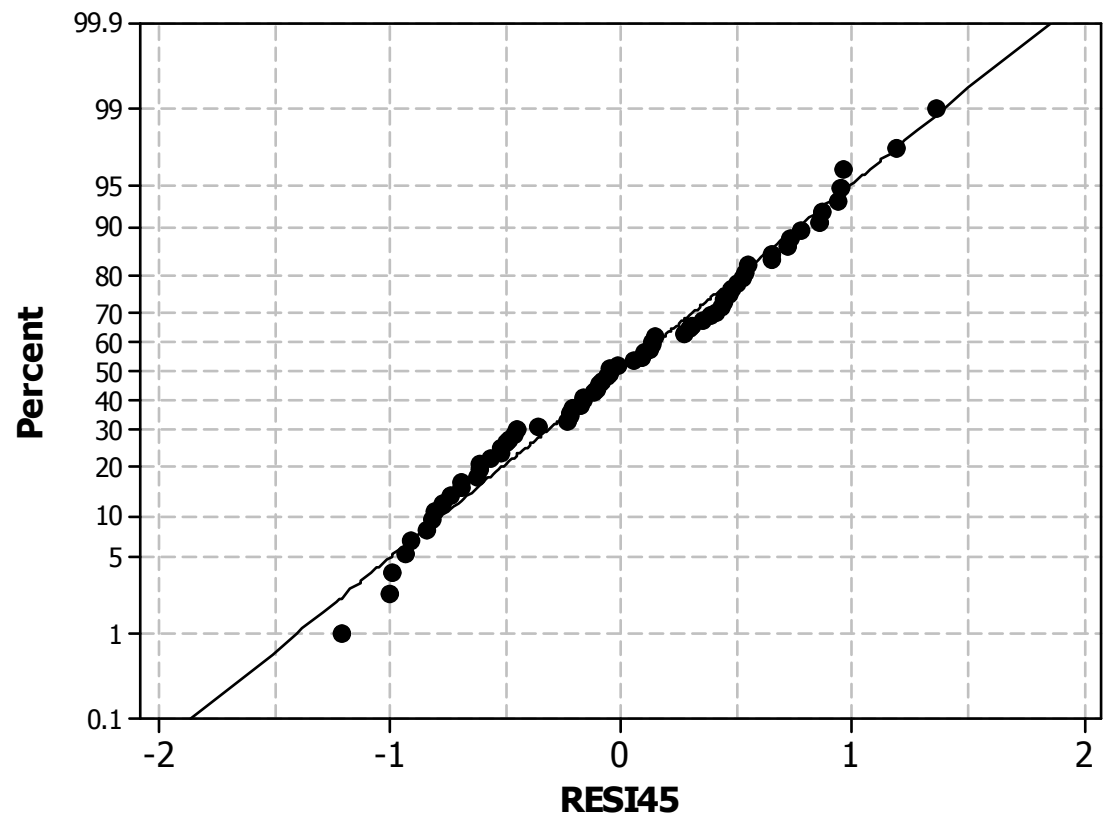

\begin{tabular}{|lr|}
\hline Mean & $-5.67447 \mathrm{E}-16$ \\
StDev & 0.6010 \\
$\mathrm{~N}$ & 72 \\
$\mathrm{RJ}$ & 0.993 \\
P-Value & $>0.100$ \\
\hline
\end{tabular}


FIGURE B9. Normality plot of residuals and summary statistics for the Ryan Joiner test of normality for the global model of Spotted Towhee.

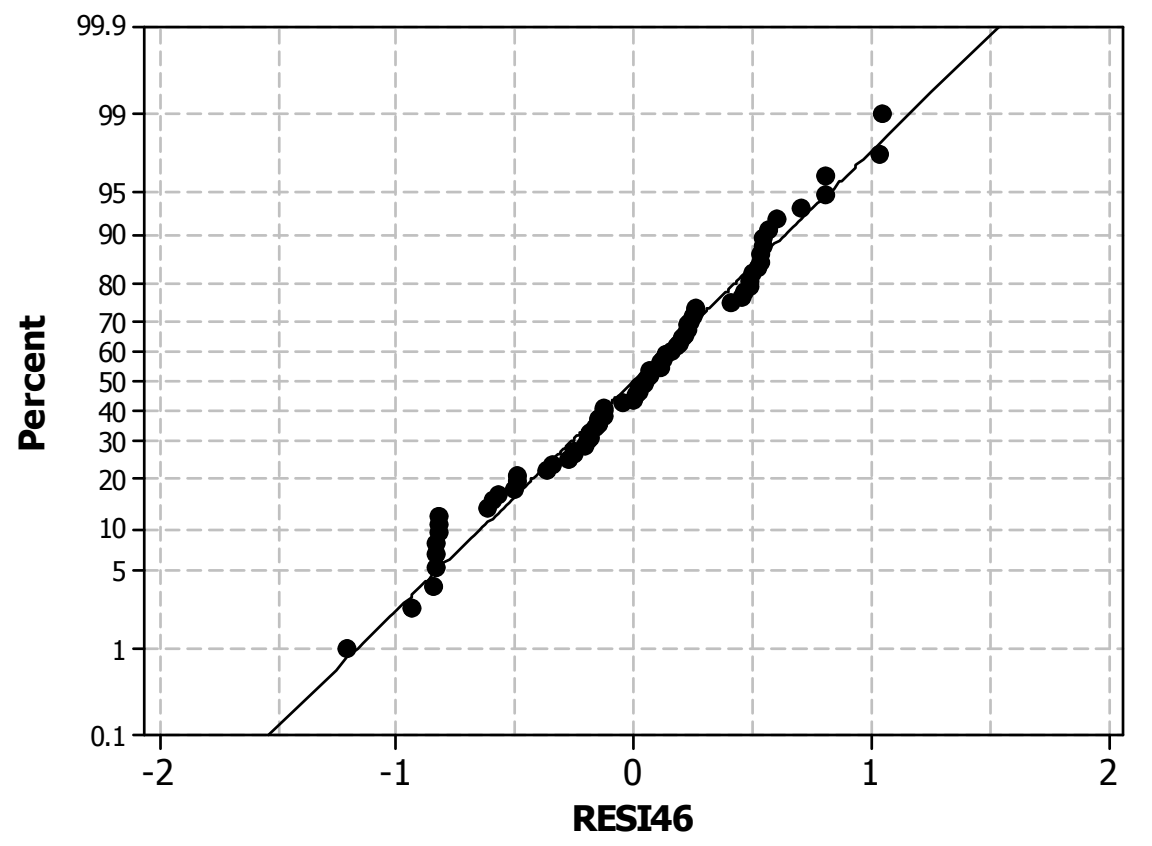

\begin{tabular}{|lr|}
\hline Mean & $-9.03598 \mathrm{E}-16$ \\
StDev & 0.4994 \\
$\mathrm{~N}$ & 72 \\
$\mathrm{RJ}$ & 0.991 \\
P-Value & $>0.100$ \\
\hline
\end{tabular}

FIGURE B10. Normality plot of residuals and summary statistics for the Ryan Joiner test of normality for the global model of Pacific-slope Flycatcher.

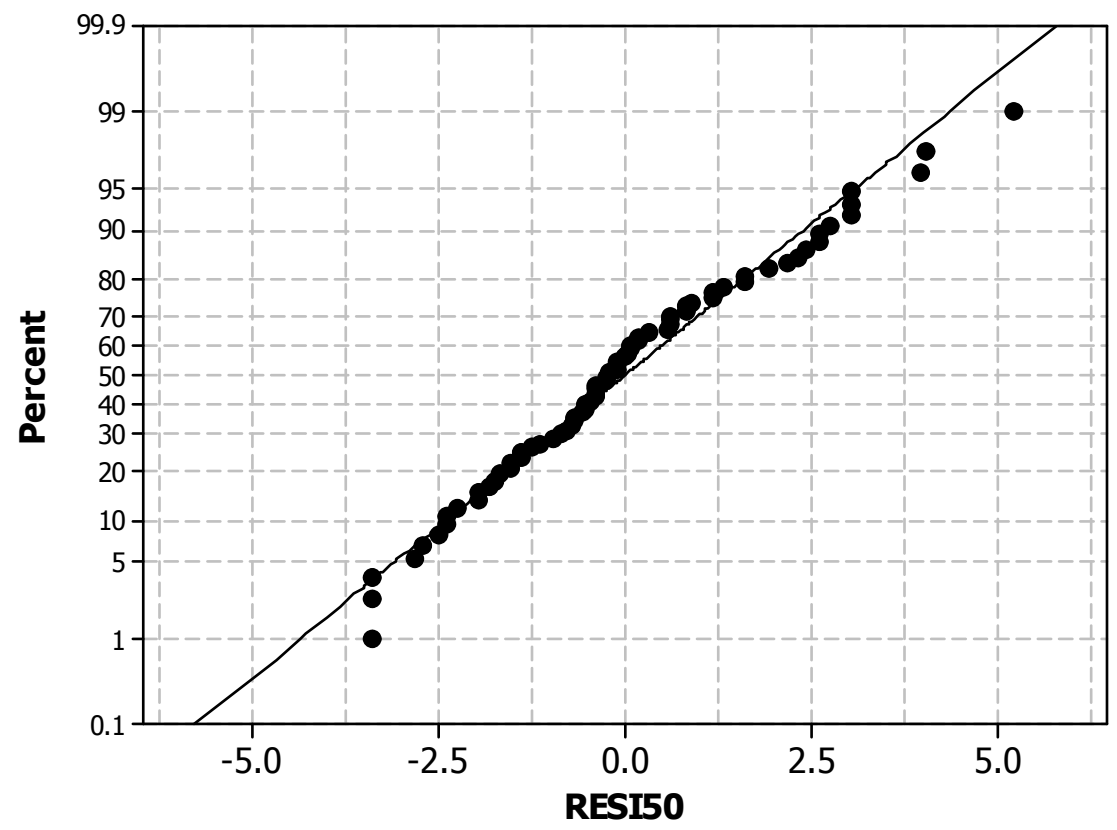

\begin{tabular}{|lr|}
\hline Mean & $-2.01074 \mathrm{E}-15$ \\
StDev & 1.868 \\
$\mathrm{~N}$ & 72 \\
$\mathrm{RJ}$ & 0.991 \\
P-Value & $>0.100$ \\
\hline
\end{tabular}


FIGURE B11. Scatter Plots of the residual values vs. the fitted values for the global model of Orange-crowned Warbler.

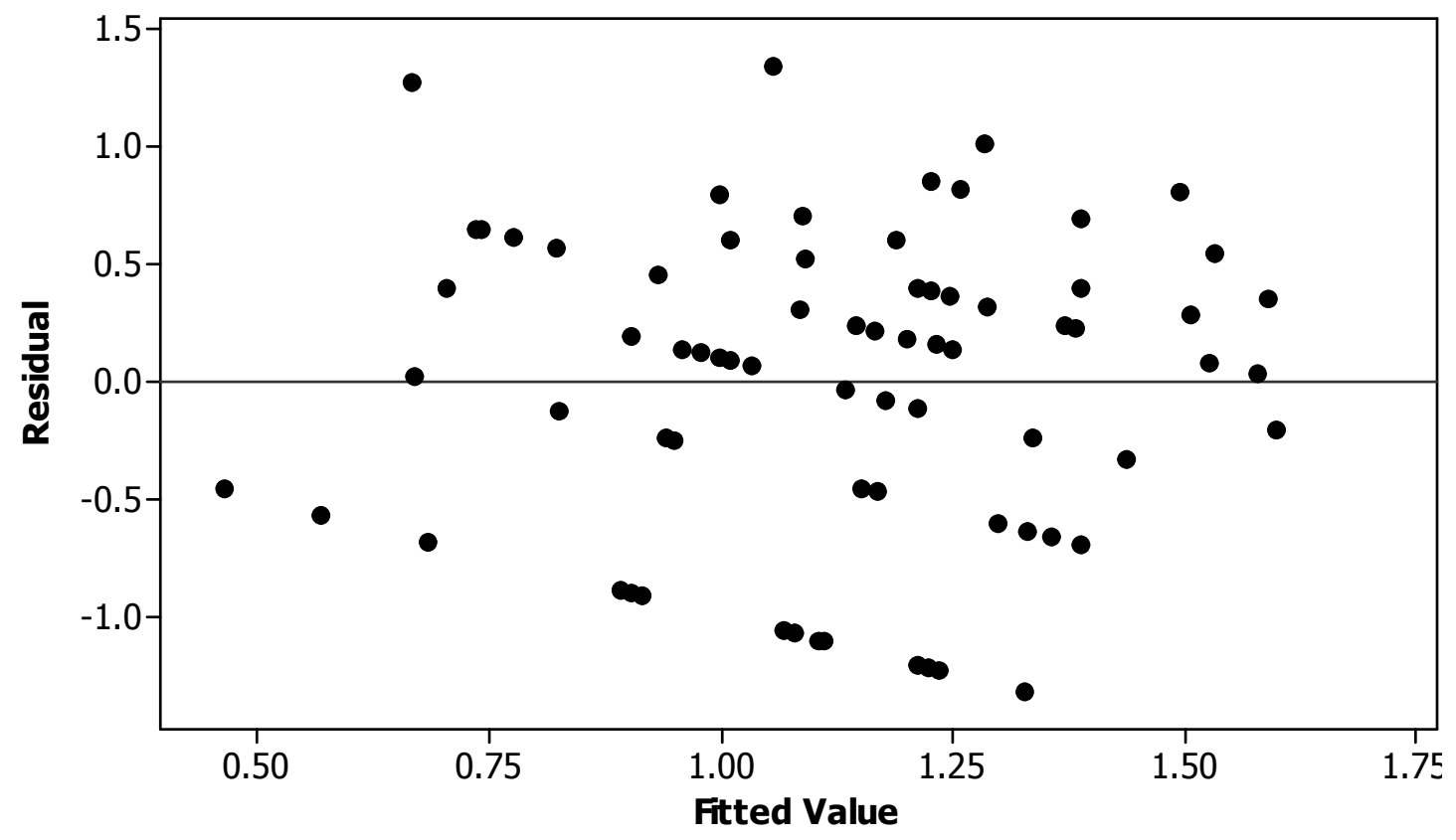

FIGURE B12. Scatter Plots of the residual values vs. the fitted values for the global model of Song Sparrow.

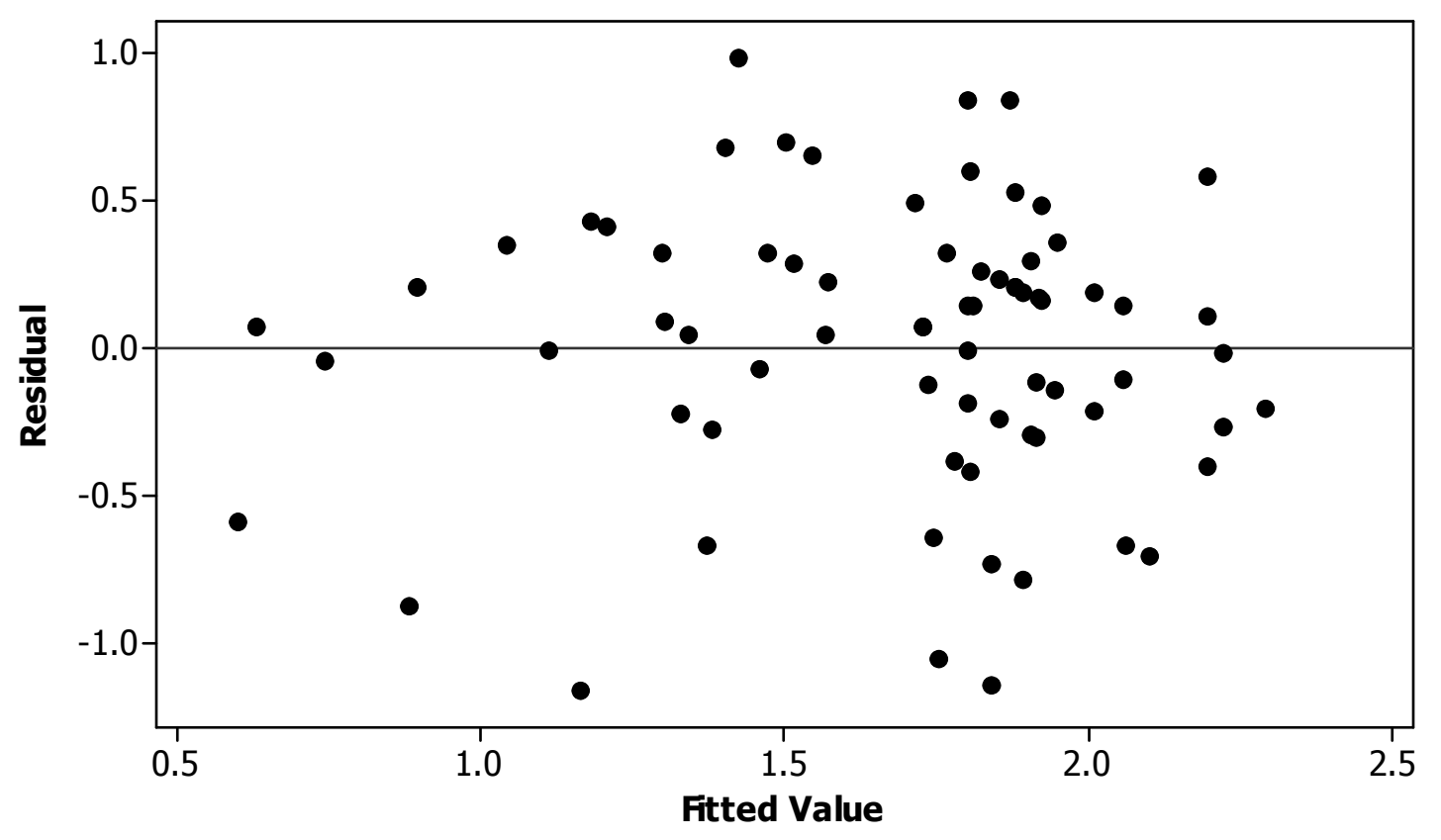


FIGURE B13. Scatter Plots of the residual values vs. the fitted values for the global model of Warbling Vireo.

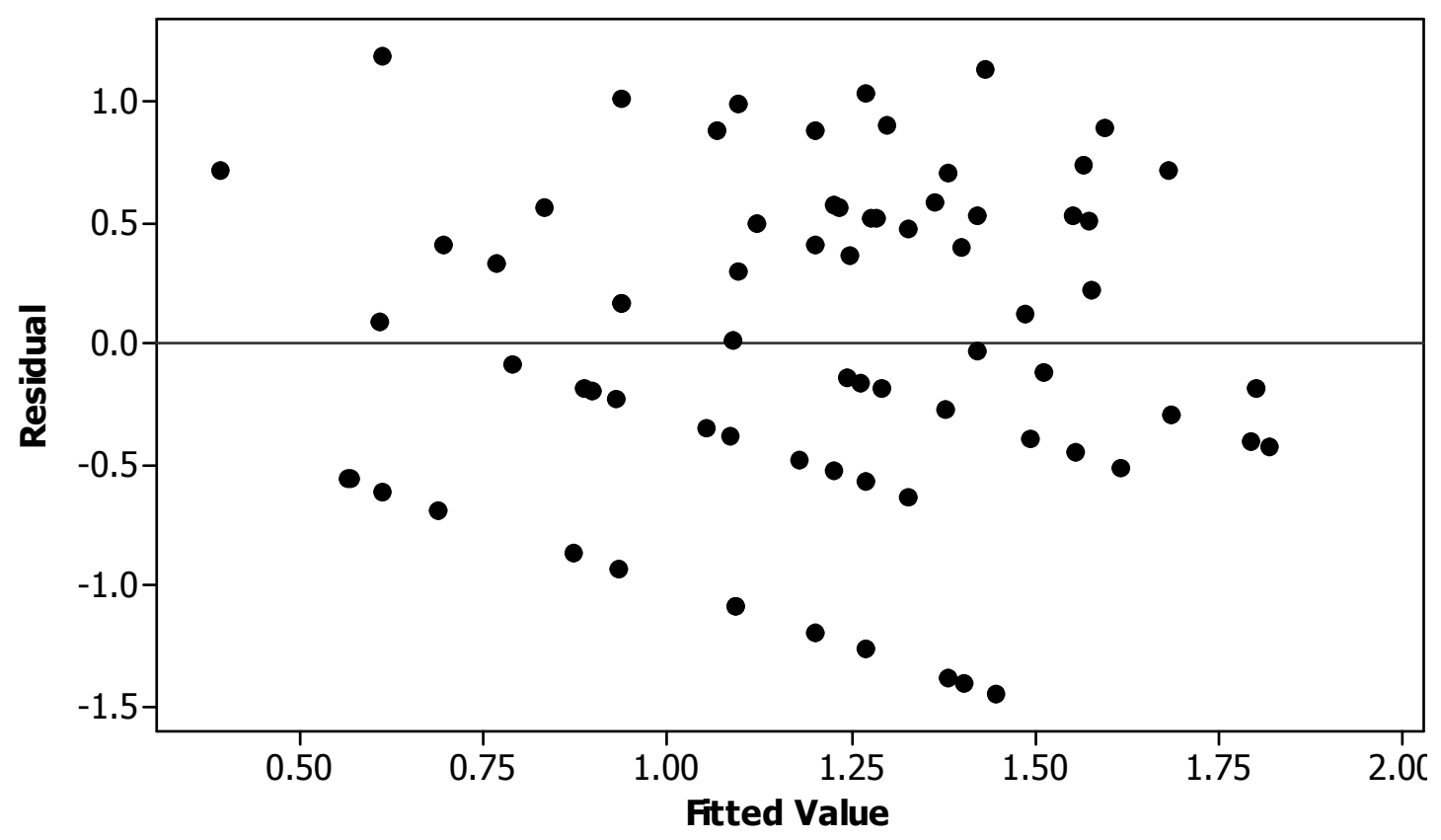

FIGURE B14. Scatter Plots of the residual values vs. the fitted values for the global model of Wilson's Warbler.

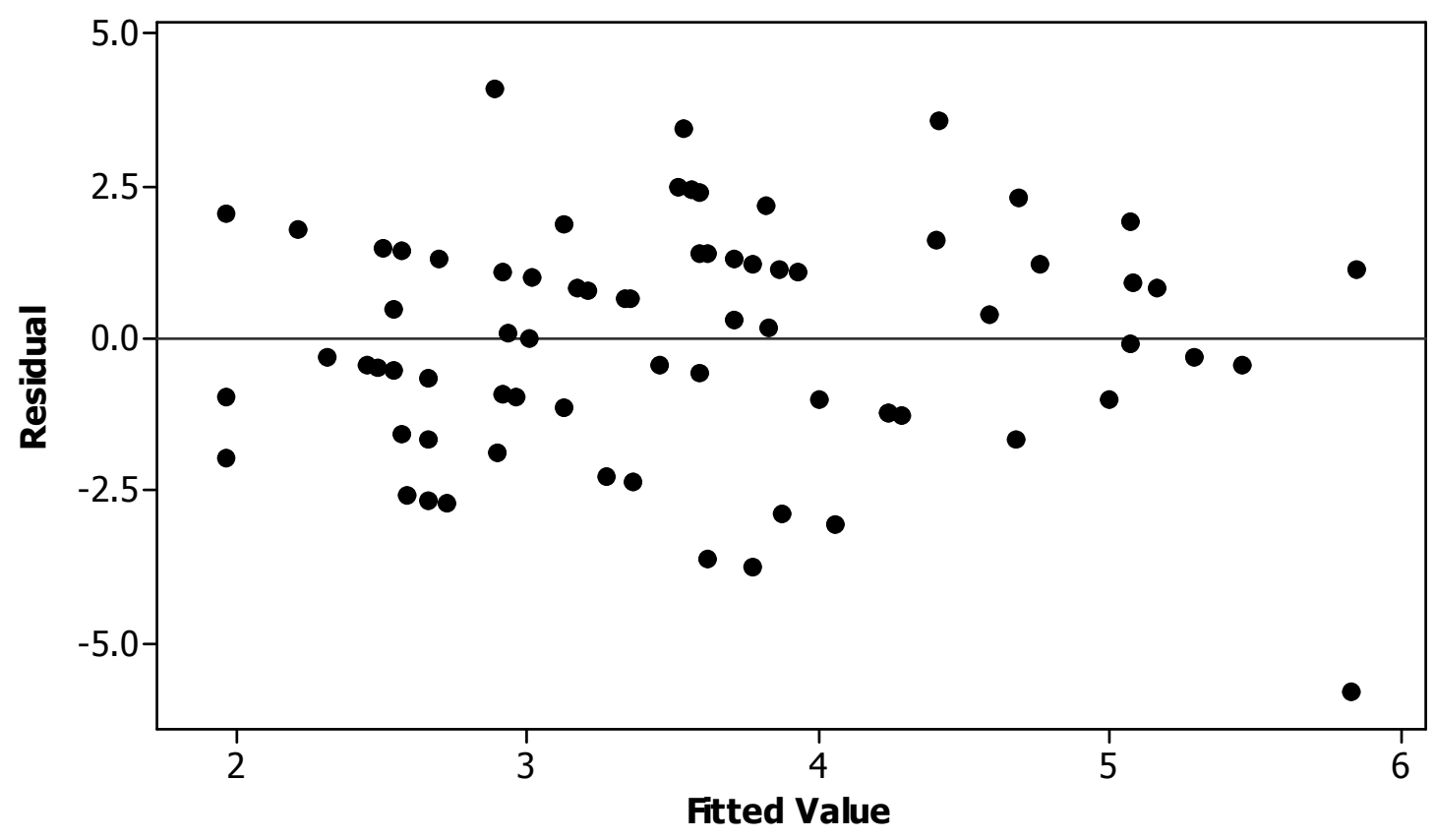


FIGURE B15. Scatter Plots of the residual values vs. the fitted values for the global model of Black-headed Grosbeak.

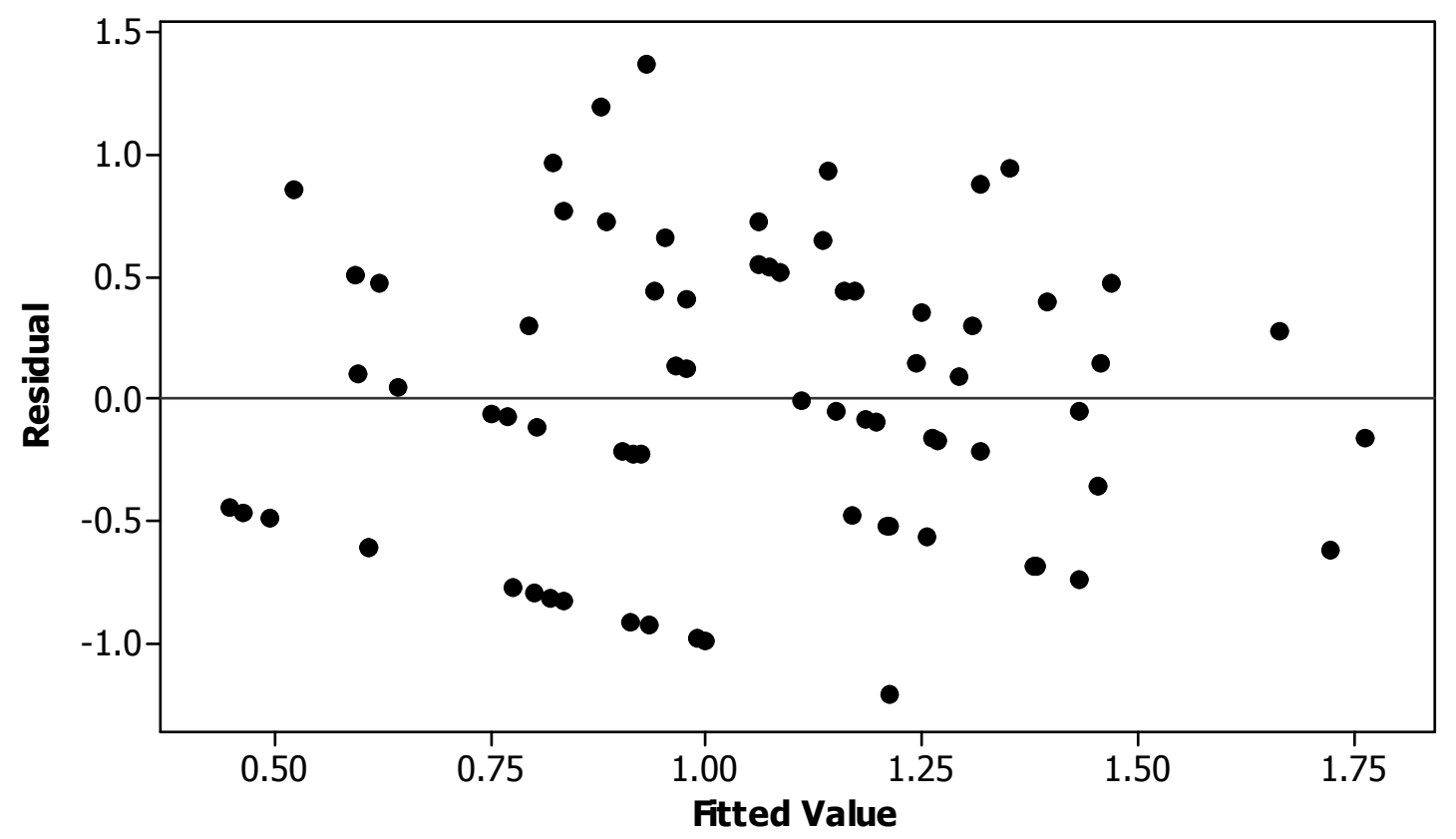

FIGURE B16. Scatter Plots of the residual values vs. the fitted values for the global model of Spotted Towhee.

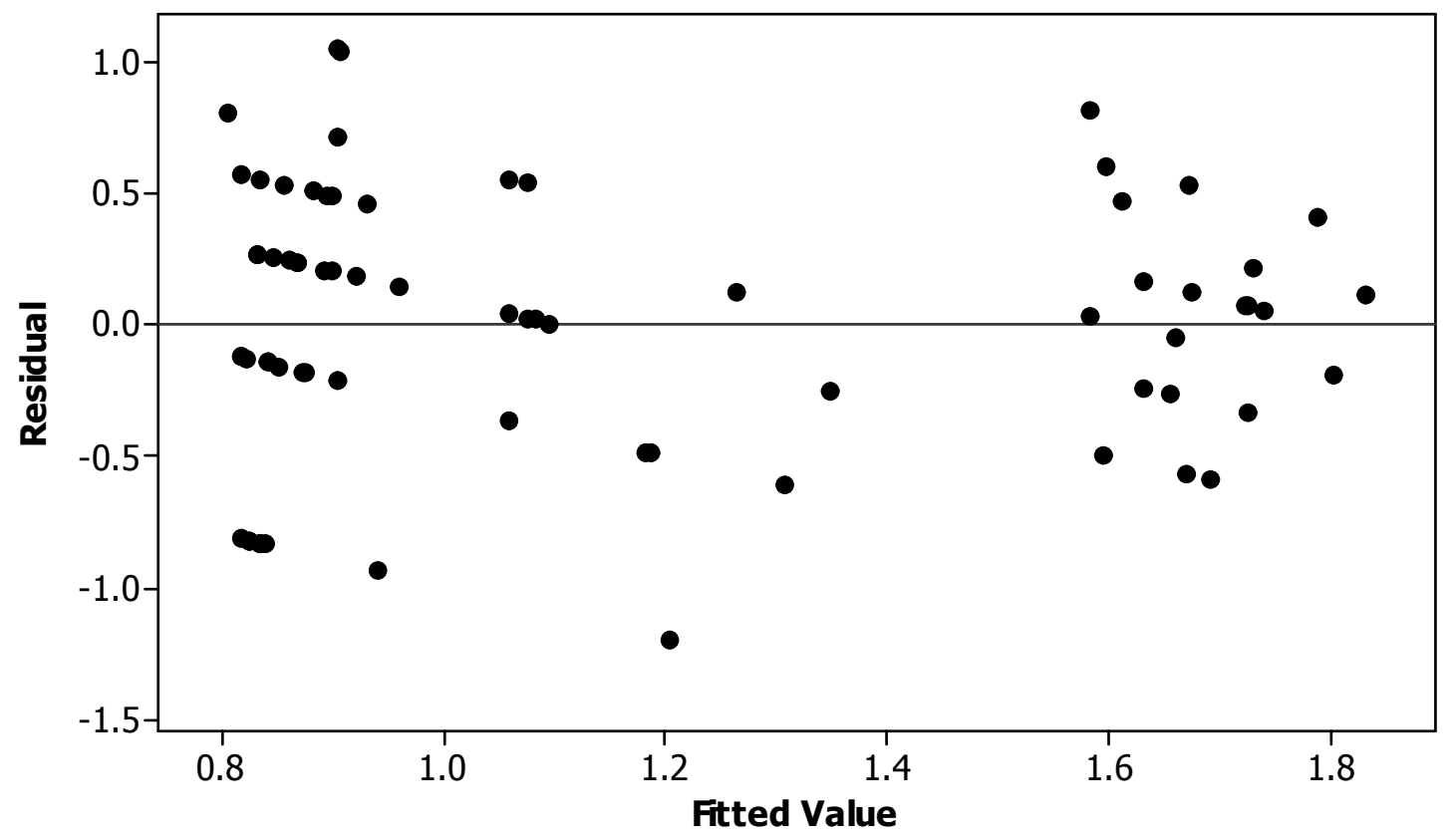


FIGURE B17. Scatter Plots of the residual values vs. the fitted values for the global model of Pacific Slope Flycatcher.

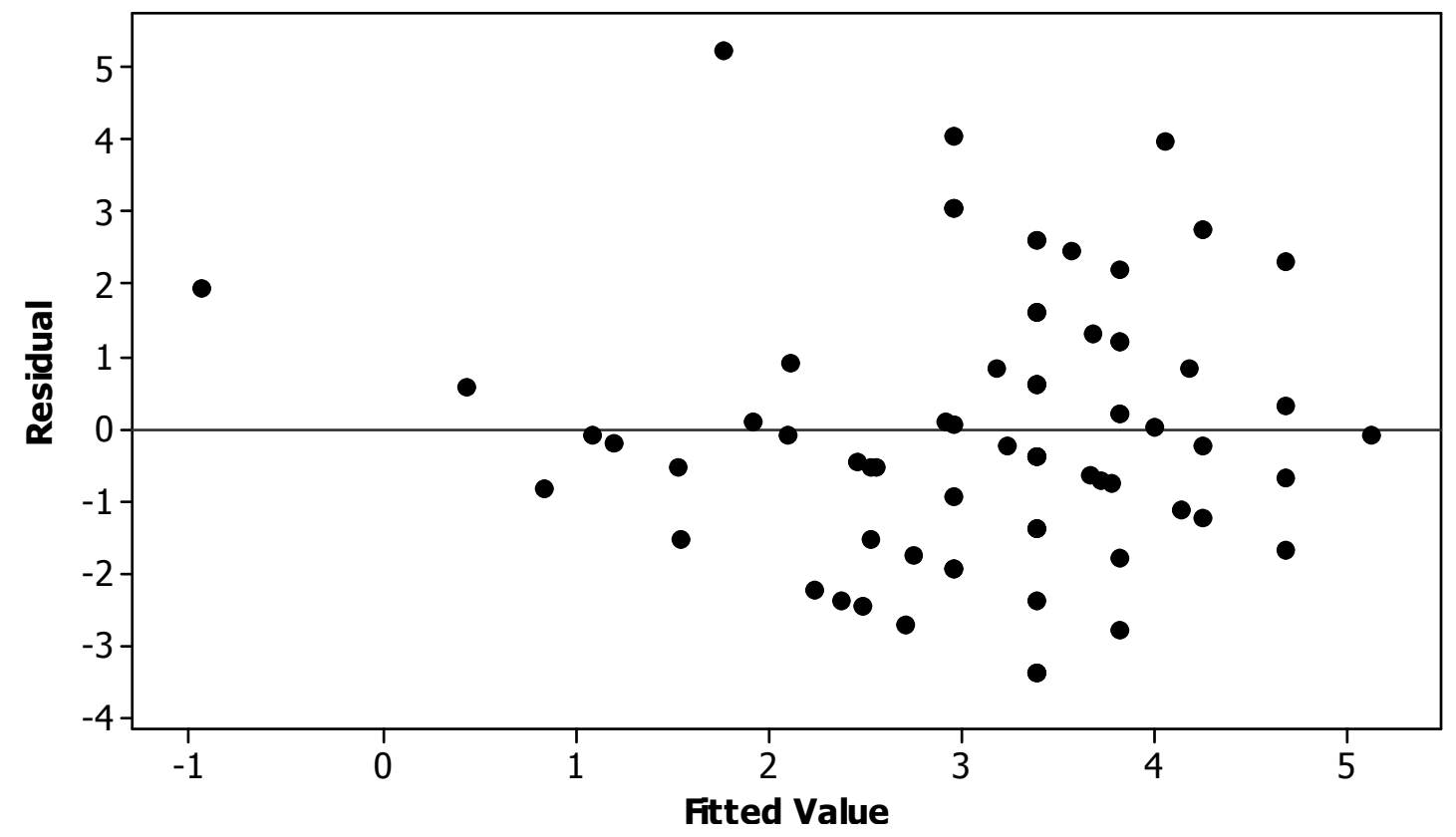

FIGURE B18. Scatter Plots of the residual values vs. the fitted values for the global model of Swainson's Thrush.

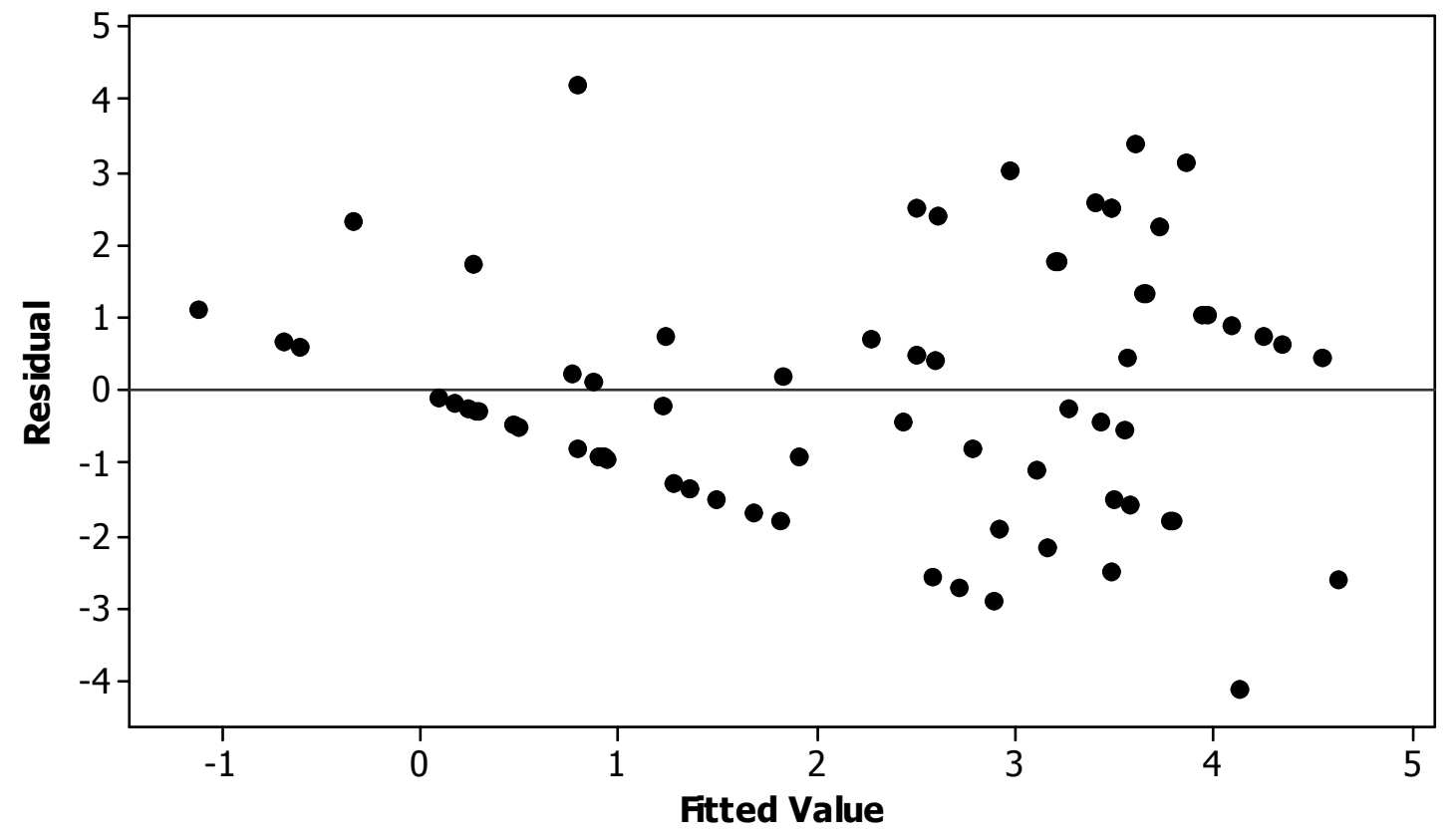




\section{Appendix C. Summary of bird and plant species detected during the study duration}

TABLE C1. The common name, scientific name, and summary detections of bird species at sampling plots $(n=96)$ throughout the study period.

\begin{tabular}{|c|c|c|c|c|}
\hline COMMON NAME & SCIENTIFIC NAME & BANDING CODE & $\begin{array}{c}\text { TOTAL } \\
\text { DETECTIONS }\end{array}$ & $\begin{array}{l}\text { DETECTIONS } \\
\text { WITHIN } 50 \mathrm{M}\end{array}$ \\
\hline Acorn Woodpecker & Melanerpes formicivorus & ACWO & 72 & 24 \\
\hline Allen's Hummingbird & Selasphorus sasin & ALHU & 7 & 5 \\
\hline American Bittern & Botaurus lentiginosus & AMBI & 1 & \\
\hline American Crow & Corvus brachyrhynchos & AMCR & 157 & 29 \\
\hline American Goldfinch & Spinus tristus & AMGO & 44 & 11 \\
\hline American Kestrel & Falco sparverius & AMKE & 7 & 1 \\
\hline American Robin & Turdus migratorius & AMRO & 62 & 29 \\
\hline Anna's Hummingbird & Calypte anna & ANHU & 48 & 44 \\
\hline Ash-throated Flycatcher & Myiarchus cinerascens & ATFL & 172 & 16 \\
\hline Bald Eagle & Haliaeetus leucocephalus & BAEA & 1 & \\
\hline Band-tailed Pigeon & Columba fasciata & BTPI & 36 & 10 \\
\hline Barn Owl & Tyto alba & BANO & 1 & \\
\hline Barn Swallow & Hirundo rustica & BARS & 25 & \\
\hline Belted Kingfisher & Ceryle alcyon & BEKI & 4 & 1 \\
\hline Bewick's Wren & Thryomanes bewickii & BEWR & 217 & 125 \\
\hline Black Phoebe & Sayornis nigricans & BLPH & 20 & 13 \\
\hline Black-chinned Hummingbird & Archilochus alexandri & $\mathrm{BCHU}$ & 25 & 24 \\
\hline Black-crowned Night-Heron & Nycticorax nycticorax & $\mathrm{BCNH}$ & 1 & \\
\hline Black-headed Grosbeak & Pheucticus melanocephalus & BHGR & 394 & 219 \\
\hline Black-throated Gray Warbler & Dendroica nigrescens & BTYW & 5 & 5 \\
\hline Blue Grosbeak & Passerina caerulea & BLGR & 4 & 2 \\
\hline Blue-gray Gnatcatcher & Polioptila caerulea & BGGN & 2 & 2 \\
\hline Brewer's Blackbird & Euphagus cyanocephalus & BRBB & 44 & 23 \\
\hline Brown Creeper & Certhia americana & BRCR & 33 & 26 \\
\hline Brown-headed Cowbird & Molothrus ater & $\mathrm{BHCO}$ & 85 & 33 \\
\hline Bullock's Oriole & Icterus bullockii & BUOR & 33 & 16 \\
\hline Bushtit & Psaltriparus minimus & $\mathrm{BUSH}$ & 233 & 173 \\
\hline California Quail & Callipepla californica & CAQU & 109 & 15 \\
\hline California Thrasher & Toxostoma redivivum & CATH & 11 & 6 \\
\hline California Towhee & Pipilo crissalis & CALT & 104 & 61 \\
\hline Canada Goose & Branta canadensis & CANG & 3 & \\
\hline Canyon Wren & Catherpes mexicanus & CAWR & 6 & 3 \\
\hline Cassin's Kingbird & Tyrannus vociferans & CAKI & 1 & \\
\hline Cassin's Vireo & Vireo cassinii & CAVI & 13 & 10 \\
\hline Cedar Waxwing & Bombycilla cedrorum & CEDW & 217 & 94 \\
\hline Chestnut-backed Chickadee & Poecile rufescens & $\mathrm{CBCH}$ & 452 & 416 \\
\hline Cliff Swallow & Petrochelidon pyrrhonota & CLSW & 261 & \\
\hline Common Goldeneye & Bucephala clangula & COGO & 1 & 1 \\
\hline Common Peafowl & Pavo cristatus & COPE & 1 & \\
\hline Common Raven & Corvus corax & CORA & 4 & \\
\hline Common Yellowthroat & Geothlypis thrichas & COYE & 16 & 12 \\
\hline Cooper's Hawk & Accipiter cooperii & $\mathrm{COHA}$ & 7 & 1 \\
\hline Costa's Hummingbird & Calypte costae & $\mathrm{COHU}$ & 2 & 2 \\
\hline
\end{tabular}


TABLE C1 continued. The common name, scientific name, and summary detections of bird species at sampling plots $(n=96)$ throughout the study period.

\begin{tabular}{|c|c|c|c|c|}
\hline COMMON NAME & SCIENTIFIC NAME & BANDING CODE & $\begin{array}{c}\text { TOTAL } \\
\text { DETECTIONS }\end{array}$ & $\begin{array}{l}\text { DETECTIONS } \\
\text { WITHIN } 50 \mathrm{M}\end{array}$ \\
\hline Dark-eyed Junco & Junco hyemalis & DEJU & 153 & 99 \\
\hline Double-crested Cormorant & Phalacrocorax auritus & DCCO & 8 & \\
\hline Downy Woodpecker & Picoides pubescens & DOWO & 48 & 24 \\
\hline Eurasian Collared Dove & Streptopelia decaocto & EUCD & 88 & 28 \\
\hline European Starling & Sturnus vulgaris & EUST & 228 & 75 \\
\hline Golden Eagle & Aquila chrysaetos & GOEA & 1 & \\
\hline Golden-crowned Sparrow & Zonotrichia atricapilla & GCSP & 1 & 1 \\
\hline Great Blue Heron & Ardea herodias & GBHE & 8 & \\
\hline Great Egret & Ardea alba & GREG & 2 & 2 \\
\hline Great Horned Owl & Bubo virginianus & GHOW & 10 & 1 \\
\hline Greater Roadrunner & Geococcyx californianus & GRRO & 1 & \\
\hline Greater Yellowlegs & Tringa melanoleuca & GRYE & 1 & \\
\hline Green Heron & Butorides virescens & GRHE & 3 & 1 \\
\hline Hairy Woodpecker & Picoides villosus & HAWO & 38 & 22 \\
\hline Hermit Thrush & Catharus guttatus & HETH & 2 & 2 \\
\hline Hermit Warbler & Dendroica occidentalis & HEWA & 4 & 3 \\
\hline Hooded Oriole & Icterus cucullatus & HOOR & 1 & 1 \\
\hline House Finch & Carpodacus mexicanus & HOFI & 196 & 30 \\
\hline House Sparrow & Passer domesticus & HOSP & 19 & 19 \\
\hline House Wren & Troglodytes aedon & HOWR & 308 & 144 \\
\hline Hutton's Vireo & Vireo huttoni & HUVI & 53 & 42 \\
\hline Killdeer & Charadrius vociferus & KILL & 10 & 4 \\
\hline Lark Sparrow & Chondestes grammacus & LASP & 3 & \\
\hline Lawrence's Goldfinch & Spinus lawrencei & LAGO & 10 & \\
\hline Lazuli Bunting & Passerina amoena & LAZB & 66 & 33 \\
\hline Lesser Goldfinch & Spinus psaltria & LEGO & 101 & 30 \\
\hline MacGillivray's Warbler & Oporornis tolmiei & MGWA & 24 & 17 \\
\hline Mallard & Anas platyrhynchos & MALL & 29 & 15 \\
\hline Mountain Quail & Oreortyx pictus & MOQU & 5 & \\
\hline Mourning Dove & Zenaida macroura & MODO & 130 & 24 \\
\hline Nashville Warbler & Vermivora ruficapilla & NAWA & 2 & 1 \\
\hline Northern Flicker & Colaptes auratus & NOFL & 60 & 14 \\
\hline Northern Mockingbird & Mimus polyglottos & NOMO & 9 & 2 \\
\hline Northern Rough-winged Swallow & Stelgidopteryx serripennis & NRWS & 23 & \\
\hline Nuttall's Woodpecker & Picoides nuttallii & NUWO & 124 & 38 \\
\hline Oak Titmouse & Baeolophus inornatus & OATI & 110 & 42 \\
\hline Olive-sided Flycatcher & Contopus cooperi & OSFL & 8 & 4 \\
\hline Orange-crowned Warbler & Vermivora celata & OCWA & 344 & 255 \\
\hline Pacific-slope Flycatcher & Empidonax difficilis & PSFL & 335 & 268 \\
\hline Phainopepla & Phainopepla nitens & PHAI & 1 & \\
\hline Pine Siskin & Spinus pinus & PISI & 1 & \\
\hline Purple Finch & Carpodacus purpureus & PUFI & 118 & 51 \\
\hline Pygmy Nuthatch & Sitta pygmaea & PYNU & 13 & 12 \\
\hline
\end{tabular}


TABLE C1 continued. The common name, scientific name, and summary detections of bird species at sampling plots $(n=96)$ throughout the study period.

\begin{tabular}{|c|c|c|c|c|}
\hline COMMON NAME & SCIENTIFIC NAME & BANDING CODE & $\begin{array}{c}\text { TOTAL } \\
\text { DETECTIONS }\end{array}$ & $\begin{array}{l}\text { DETECTIONS } \\
\text { WITHIN } 50 \mathrm{M}\end{array}$ \\
\hline$\overline{\text { Red Junglefowl }}$ & Gallus gallus & REJU & 1 & \\
\hline Red-shouldered Hawk & Buteo lineatus & RSHA & 24 & 6 \\
\hline Red-tailed Hawk & Buteo jamaicensis & RTHA & 29 & 2 \\
\hline Red-winged Blackbird & Agelaius phoeniceus & RWBL & 69 & 6 \\
\hline Rock Pigeon & Columba livia & ROPI & 29 & \\
\hline Rose-breasted Grosbeak & Pheucticus ludovicianus & RBGR & 1 & 1 \\
\hline Ruby-crowned Kinglet & Regulus calendula & RCKI & 2 & 2 \\
\hline Rufous/Allen's Hummingbird & Selasphorus spp. & SESP & 29 & 19 \\
\hline Sharp-shinned Hawk & Accipiter striatus & SSHA & 1 & \\
\hline Song Sparrow & Melospiza melodia & SOSP & 670 & 457 \\
\hline Spotted Sandpiper & Actitis macularia & SPSA & 1 & 1 \\
\hline Spotted Towhee & Pipilo maculatus & SPTO & 360 & 234 \\
\hline Steller's Jay & Cyanocitta stelleri & STJA & 186 & 94 \\
\hline Swainson's Thrush & Catharus ustulatus & SWTH & 273 & 210 \\
\hline Townsend's Warbler & Dendroica townsendi & TOWA & 5 & 5 \\
\hline Tree Swallow & Tachycineta bicolor & TRES & 193 & 1 \\
\hline Tricolored Blackbird & Agelaius tricolor & TRBL & 30 & \\
\hline Turkey Vulture & Cathartes aura & TUVU & 25 & 2 \\
\hline Violet-green Swallow & Tachycineta thalassina & VGSW & 94 & 3 \\
\hline Warbling Vireo & Vireo gilvus & WAVI & 385 & 281 \\
\hline Western Bluebird & Sialia mexicana & WEBL & 45 & 6 \\
\hline Western Gull & Larus occidentalis & WEGU & 1 & \\
\hline Western Kingbird & Tyrannus verticalis & WEKI & 9 & 2 \\
\hline Western Meadowlark & Sturnella neglecta & WEME & 11 & \\
\hline Western Scrub-Jay & Aphelocoma californica & WESJ & 180 & 76 \\
\hline Western Tanager & Piranga ludoviciana & WETA & 42 & 14 \\
\hline Western Wood-Pewee & Contopus sordidulus & WWPE & 63 & 34 \\
\hline White-breasted Nuthatch & Sitta carolinensis & WBNU & 55 & 1 \\
\hline White-crowned Sparrow & Zonotrichia leucophrys & WCSP & 4 & 1 \\
\hline White-tailed Kite & Elanas leucurus & WTKI & 5 & \\
\hline White-throated Swift & Aeronautes saxatalis & WTSW & 2 & \\
\hline Wild Turkey & Meleagris gallopavo & WITU & 3 & 1 \\
\hline Wilson's Warbler & Wilsonia pusilla & WIWA & 436 & 344 \\
\hline Pacific Wren & Troglodytes pacificus & PAWR & 13 & 12 \\
\hline Wood Duck & Aix sponsa & WODU & 4 & \\
\hline Wrentit & Chamaea fasciata & WREN & 269 & 55 \\
\hline Yellow Warbler & Dendroica petechia & YWAR & 61 & 49 \\
\hline Yellow-breasted Chat & Icteria virens & YBCH & 5 & 2 \\
\hline Yellow-rumped Warbler & Dendroica coronata & YRWA & 2 & 2 \\
\hline
\end{tabular}


TABLE C2. The family, scientific name, common name and origin status of plant species identified during relevé surveys within $50 \mathrm{~m}$ radius $(0.785 \mathrm{ha})$ sampling plots $(\mathrm{n}=96)$ within the canopy height strata $(>5.0 \mathrm{~m})$.

\begin{tabular}{|c|c|c|c|}
\hline FAMILY & TAXON & STATUS & COMMON NAME \\
\hline Aceraceae & Acer macrophyllum & Native & big leaf maple \\
\hline Aceraceae & Acer negundo & Native & California Box Elder \\
\hline Anacardiaceae & Toxicodendron diversilobum & Native & poison oak \\
\hline Betulaceae & Alnus rhombifolia & Native & white alder \\
\hline Betulaceae & Alnus rhombifolia & Native & white alder \\
\hline Caprifoliaceae & Lonicera involcrata & Native & coast twinberry \\
\hline Caprifoliaceae & Sambucus mexicana & Native & blue elderberry \\
\hline Cornaceae & Cornus sericea & Native & red-stem dogwood \\
\hline Ericaceae & Arbutus menziesii & Native & Pacific madrone \\
\hline Fagaceae & Lithocarpus densiflorus & Native & tanbark oak \\
\hline Fagaceae & Quercus agrifolia & Native & coast live oak \\
\hline Fagaceae & Quercus lobata & Native & valley oak \\
\hline Juglandaceae & Juglans californica & Native & California black walnut \\
\hline Lauraceae & Umbellaria californica & Native & California bay \\
\hline Lauraceae & Umbellaria californica & Native & California bay \\
\hline Myrtaceae & Eucalyptus globulus & Non-native & blue eucalyptus \\
\hline Myrtaceae & Eucalyptus tereticornis & Non-native & forest red gum \\
\hline Oleaceae & Fraxinus latifolia & Native & Oregon ash \\
\hline Pinacea & Pinus coulteri & Native & Coulter pine \\
\hline Pinacea & Pinus radiata & Native & Monterey pine \\
\hline Pinacea & Pinus sabiniana & Native & grey pine \\
\hline Pinacea & Pseudotsuga menziesii & Native & douglas fir \\
\hline Platanaceae & Platanus racemosa & Native & western sycamore \\
\hline Rosaceae & Heteromeles arbutifolia & Native & toyon \\
\hline Rosaceae & Prunus ilicifolia & Native & holly leaf cherry \\
\hline Rosaceae & Prunus ilicifolia & Native & holly leaf cherry \\
\hline Salicaceae & Populus balsamifera & Native & black cottonwood \\
\hline Salicaceae & Populus fremontii & Native & Fremont's cottonwood \\
\hline Salicaceae & Salix laevigata & Native & red willow \\
\hline Salicaceae & Salix lasiolepus & Native & arroyo willow \\
\hline Taxodiaceae & Sequoia sempervirens & Non-native & redwood \\
\hline
\end{tabular}


TABLE C3. The family, scientific name, common name and origin status of plant species identified during relevé surveys within $50 \mathrm{~m}$ radius $(0.785 \mathrm{ha})$ sampling plots $(\mathrm{n}=96)$ within the shrub height strata $(>1.0-5.0 \mathrm{~m})$.

\begin{tabular}{|c|c|c|c|}
\hline FAMILY & TAXON & STATUS & SHRUB \\
\hline Aceraceae & Acer macrophyllum & Native & big leaf maple \\
\hline Aceraceae & Acer negundo & Native & California Box Elder \\
\hline Anacardiaceae & Toxicodendron diversilobum & Native & poison oak \\
\hline Asteraceae & Artemesia californica & Native & California sagebrush \\
\hline Asteraceae & Artemesia douglasiana & Native & mugwort \\
\hline Asteraceae & Aster spp. & Native & aster species \\
\hline Asteraceae & Baccharis pilularis & Native & coyote brush \\
\hline Asteraceae & Baccharis salicifolia & Native & mulefat \\
\hline Betulaceae & Alnus rhombifolia & Native & white alder \\
\hline Caprifoliaceae & Lonicera involcrata & Native & coast twinberry \\
\hline Caprifoliaceae & Sambucus mexicana & Native & blue elderberry \\
\hline Caprifoliaceae & Symphoricarpos albus & Native & common snowberry \\
\hline Cornaceae & Cornus sericea & Native & red-stem dogwood \\
\hline Cucurbitaceae & Marah fabaceus & Native & California manroot \\
\hline Dennstaedtiaceae & Pteridium aquilinum & Native & western bracken fern \\
\hline Dryopteridaceae & Polystichum munitum & Native & western sword fern \\
\hline Fabaceae & Genista monspessulana & Non-native & French broom \\
\hline Fagaceae & Lithocarpus densiflorus & Native & tanbark oak \\
\hline Fagaceae & Quercus agrifolia & Native & coast live oak \\
\hline Fagaceae & Quercus durata & Native & leather oak \\
\hline Grossulariaceae & Ribes speciosum & Native & fuchsiaflower gooseberry \\
\hline Juglandaceae & Juglans californica & Native & California black walnut \\
\hline Lamiaceae & Salvia mellifera & Native & black sage \\
\hline Lauraceae & Umbellaria californica & Native & California bay \\
\hline Oleaceae & Foresteria pubescens & Native & desert olive \\
\hline Pinacea & Pinus radiata & Native & Monterey pine \\
\hline Platanaceae & Platanus racemosa & Native & western sycamore \\
\hline Poaceae & Arundo donax & Non-native & giant reed \\
\hline Polygonaceae & Eriogonum fasciculatum & Native & California buckwheat \\
\hline Pteridaceae & Adiantum jordanii & Native & California maiden hair fern \\
\hline Rhamnaceae & Ceanothus cuneatus & Native & buckbrush \\
\hline Rhamnaceae & Rhamnus californica & Native & coffee berry \\
\hline Rhamnaceae & Rhamnus crocea & Native & redberry \\
\hline Rhamnaceae & Rhamnus ilicifolia & Native & hollyleaf redberry \\
\hline Rosaceae & Cercocarpus betuloides & Native & mountain mohogany \\
\hline Rosaceae & Heteromeles arbutifolia & Native & toyon \\
\hline Rosaceae & Prunus ilicifolia & Native & holly leaf cherry \\
\hline Rosaceae & Rosa californica & Native & California wild rose \\
\hline Rosaceae & Rubus discolor & Non-native & Himalayan blackberry \\
\hline Rosaceae & Rubus parviflorus & Native & western thimbleberry \\
\hline Rosaceae & Rubus ursinus & Native & California blackberry \\
\hline Salicaceae & Populus balsamifera & Native & black cottonwood \\
\hline Salicaceae & Populus fremontii & Native & Fremont's cottonwood \\
\hline Salicaceae & Salix breweri & Native & serpentine willow \\
\hline Salicaceae & Salix exigua & Native & sandbar willow \\
\hline Salicaceae & Salix laevigata & Native & red willow \\
\hline Salicaceae & Salix lasiolepus & Native & arroyo willow \\
\hline Scrophulariaceae & Mimulus aurantiacus & Native & sticky monkeyflower \\
\hline Solanaceae & Nicotiana glauca & Non-native & tree tobacco \\
\hline
\end{tabular}


TABLE C4. The family, scientific name, common name and origin status of plant species identified during relevé surveys within $50 \mathrm{~m}$ radius $(0.785 \mathrm{ha})$ sampling plots $(n=96)$ within the herbaceous height strata $(>0.0-1.0 \mathrm{~m})$.

\begin{tabular}{|c|c|c|c|}
\hline FAMILY & TAXON & STATUS & COMMON NAME \\
\hline Apiaceae & Conium maculatum & Non-native & poison hemlock \\
\hline Apiaceae & Foeniculum vulgare & Non-native & sweet fennel \\
\hline Apocynaceae & Vinca major & Non-native & periwinkle \\
\hline Araliaceae & Hedera helix & Non-native & English Ivy \\
\hline Asteraceae & Artemesia douglasiana & Native & mugwort \\
\hline Asteraceae & Artemesia dracunculus & Native & wild tarragon \\
\hline Asteraceae & Carduus pycnocephalus & Non-native & Italian thistle \\
\hline Asteraceae & Centaurea solstitialis & Non-native & yellow star thistle \\
\hline Asteraceae & Delairea odorata & Non-native & Cape ivy \\
\hline Asteraceae & Picris echioides & Native & bristly oxtongue \\
\hline Asteraceae & Silybum marianum & Non-native & milk thistle \\
\hline Asteraceae & Sonchus oleraceus & Native & common sowthistle \\
\hline Boraginaceae & Amsinckia menziesii & Native & fiddleneck \\
\hline Brassicaceae & Brassica nigra & Non-native & black mustard \\
\hline Brassicaceae & Lepidium latifolia & Non-native & pepperweed \\
\hline Brassicaceae & Raphanus raphanistrum & Non-native & wild raddish \\
\hline Cactaceae & Opuntia littoralis & Native & coastal prickly pear \\
\hline Caprifoliaceae & Lonicera involcrata & Native & coast twinberry \\
\hline Caprifoliaceae & Symphoricarpos albus & Native & common snowberry \\
\hline Caprifoliaceae & Symphoricarpos mollis & Native & creeping snowberry \\
\hline Convolvulaceae & Calystegia macrostegia & Native & island morning glory \\
\hline Cucurbitaceae & Marah fabaceus & Native & California manroot \\
\hline Cyperaceae & Carex spp. & Native & sedge spp \\
\hline Cyperaceae & Scirpus microcarpus & Native & montain bog bulrush \\
\hline Dennstaedtiaceae & Pteridium aquilinum & Native & western bracken fern \\
\hline Dryopteridaceae & Polystichum munitum & Native & western sword fern \\
\hline Equisetacea & Equisetum spp. & Native & horestail species \\
\hline Euphobiaceae & Ricinis communis & Native & castor bean \\
\hline Fabaceae & Lupin spp. & Native & lupine species \\
\hline Fabaceae & Trifolium spp. & Native & clover species \\
\hline Fabaceae & Vicia spp. & Native/Non-native & vetch species \\
\hline Juncaceae & Juncus spp. & Native & rush species \\
\hline Lamiaceae & Marrubium vulgare & Non-native & common horehound \\
\hline Lamiaceae & Salvia spathacea & Native & hummingbird sage \\
\hline Lamiaceae & Stachys bullata & Native & California hedgenettle \\
\hline Liliaceae & Lilium spp. & Native & lily species \\
\hline Liliaceae & Trilium chloropetalum & Native & common trilium \\
\hline Oxalidaceae & Oxalis corniculata & Non-native & yellow sorrel \\
\hline Plantaginaceae & Plantago major & Non-native & common plantain \\
\hline Poaceae & Arundo donax & Non-native & giant reed \\
\hline Poaceae & Avena fatua & Non-native & wild oats \\
\hline Poaceae & Bromus diandrus & Non-native & ripgut brome \\
\hline Poaceae & Bromus hordeaceus & Non-native & soft brome \\
\hline Poaceae & Bromus madritensis & Non-native & foxtail brome \\
\hline Poaceae & Bromus tectorum & Non-native & cheatgrass \\
\hline Poaceae & Leymus condensatus & Native & giant wild rye \\
\hline
\end{tabular}


TABLE C4 continued. Plant species detected within the herbaceous height strata (>0.0-1.0 m).

\begin{tabular}{cccc}
\hline FAMILY & TAXON & STATUS & COMMON NAME \\
\hline Polemonicaceae & Gilia tenuiflora & Native & slender flowered gilia \\
Polygonaceae & Rumex crispus & Non-native & curly dock \\
Polygonaceae & Rumex crispus & Non-native & curly dock \\
Portulacaceae & Claytonia perfoliata & Native & miner's lettuce \\
Pteridaceae & Adiantum jordanii & Native & California maiden hair fern \\
Ranunculaceae & Aquilegia formosa & Native & columbine \\
Rosaceae & Fragaria vesca & Native & wild strawberry \\
Rosaceae & Rubus parviflorus & Native & western thimbleberry \\
Rubiaceae & Galium aparine & Native & common bedstraw \\
Scrophulariaceae & Mimulus aurantiacus & Native & sticky monkeyflower \\
Scrophulariaceae & Mimulus guttatus & Native & seep monkeyflower \\
Solanaceae & Solanum douglasii & Native & greenspot nightshade \\
Solanaceae & Solanum xanti & Native & purple nightshade \\
Tropaeolaceae & Tropaeolum majus & Non-native & nasturtium \\
Typhaceae & Typha spp. & Native/Non-native & cattail species \\
Urticaceae & Urtica dioica & Native & hoary nettle \\
Urticaceae & Urtica urens & Native & dwarf nettle \\
\hline
\end{tabular}


Appendix D. Detection Probability Results.

TABLE D1. Detection probability estimates, standard error (SE) and $95 \%$ confidence intervals for all bird species analyzed.

\begin{tabular}{ccccc}
\hline & & & \multicolumn{2}{c}{$\begin{array}{c}\text { 95\% CONFIDENCE } \\
\text { INTERVALS }\end{array}$} \\
\cline { 4 - 5 } SPECIES & $\begin{array}{c}\text { DETECTION } \\
\text { PROBABILITY }\left(\mathrm{p}^{\wedge}\right)\end{array}$ & SE $\left(\mathrm{p}^{\wedge}\right)$ & LOWER & UPPER \\
\hline Black-headed Grosbeak & 0.94 & 0.04 & 0.87 & 1.01 \\
Orange-crowned Warbler & 0.97 & 0.02 & 0.93 & 1.01 \\
Pacific-slope Flycatcher & 0.90 & 0.05 & 0.79 & 1.00 \\
Song Sparrow & 0.96 & 0.02 & 0.93 & 0.99 \\
Spotted Towhee & 0.94 & 0.04 & 0.86 & 1.01 \\
Swainson's Thrush & 0.95 & 0.03 & 0.89 & 1.01 \\
Warbling Vireo & 0.98 & 0.01 & 0.95 & 1.00 \\
Wilson's Warbler & 0.99 & 0.01 & 0.97 & 1.00 \\
\hline
\end{tabular}


TABLE D2. Detection probability estimates by year, with standard error (SE) and $95 \%$ confidence intervals for all bird species analyzed.

\begin{tabular}{|c|c|c|c|c|c|}
\hline \multirow[b]{2}{*}{ SPECIES } & \multirow[b]{2}{*}{ YEAR } & \multirow{2}{*}{$\begin{array}{c}\text { DETECTION } \\
\text { PROBABILITY }\left(p^{\wedge}\right)\end{array}$} & \multirow[b]{2}{*}{$\operatorname{SE}\left(p^{\wedge}\right)$} & \multicolumn{2}{|c|}{$\begin{array}{l}\text { 95\% CONFIDENCE } \\
\text { INTERVALS }\end{array}$} \\
\hline & & & & LOWER & UPPER \\
\hline \multirow[t]{4}{*}{ Black-headed Grosbeak } & 2006 & 0.87 & 0.14 & 0.60 & 1.14 \\
\hline & 2007 & 0.95 & 0.07 & 0.81 & 1.08 \\
\hline & 2008 & 0.92 & 0.11 & 0.72 & 1.13 \\
\hline & 2009 & 0.98 & 0.02 & 0.94 & 1.03 \\
\hline \multirow[t]{4}{*}{ Orange-crowned Warbler } & 2006 & * Low Sample Size & & & \\
\hline & 2007 & 1.00 & 0.01 & 0.98 & 1.01 \\
\hline & 2008 & 0.89 & 0.13 & 0.64 & 1.14 \\
\hline & 2009 & 1.00 & 0.00 & 0.99 & 1.01 \\
\hline \multirow[t]{4}{*}{ Pacific-slope Flycatcher } & 2006 & 0.96 & 0.05 & 0.87 & 1.05 \\
\hline & 2007 & 0.85 & 0.17 & 0.51 & 1.18 \\
\hline & 2008 & 0.85 & 0.16 & 0.53 & 1.16 \\
\hline & 2009 & 0.89 & 0.10 & 0.69 & 1.09 \\
\hline \multirow[t]{4}{*}{ Song Sparrow } & 2006 & 0.97 & 0.03 & 0.92 & 1.02 \\
\hline & 2007 & 0.91 & 0.08 & 0.75 & 1.07 \\
\hline & 2008 & 0.99 & 0.01 & 0.97 & 1.01 \\
\hline & 2009 & 0.95 & 0.04 & 0.87 & 1.03 \\
\hline \multirow[t]{4}{*}{ Spotted Towhee } & 2006 & 0.79 & 0.23 & 0.33 & 1.25 \\
\hline & 2007 & 0.90 & 0.11 & 0.67 & 1.12 \\
\hline & 2008 & 0.96 & 0.04 & 0.88 & 1.05 \\
\hline & 2009 & 0.99 & 0.02 & 0.94 & 1.03 \\
\hline \multirow[t]{4}{*}{ Swainson's Thrush } & 2006 & 0.89 & 0.14 & 0.61 & 1.17 \\
\hline & 2007 & 1.00 & 0.00 & 0.99 & 1.01 \\
\hline & 2008 & 0.97 & 0.04 & 0.88 & 1.06 \\
\hline & 2009 & 0.78 & 0.23 & 0.33 & 1.24 \\
\hline \multirow[t]{4}{*}{ Warbling Vireo } & 2006 & 0.98 & 0.02 & 0.95 & 1.02 \\
\hline & 2007 & 0.99 & 0.01 & 0.97 & 1.01 \\
\hline & 2008 & 0.95 & 0.06 & 0.83 & 1.06 \\
\hline & 2009 & 0.97 & 0.03 & 0.92 & 1.03 \\
\hline \multirow[t]{4}{*}{ Wilson's Warbler } & 2006 & 0.95 & 0.05 & 0.86 & 1.05 \\
\hline & 2007 & 0.99 & 0.01 & 0.98 & 1.01 \\
\hline & 2008 & 0.99 & 0.01 & 0.98 & 1.01 \\
\hline & 2009 & 0.99 & 0.01 & 0.96 & 1.01 \\
\hline
\end{tabular}


Appendix E. AIC Summary

TABLE E1. Summary of all 63 models tested for Black-headed Grosbeak, including model terms, number of parameters (K), log likelihood value, AIC and AICc scores, change in AICc score ( AICc) between models, likelihood value (L) and AICc weight (Wi).

\begin{tabular}{|c|c|c|c|c|c|c|c|c|c|c|c|c|c|c|c|c|c|c|c|c|}
\hline MODEL & CONSTANT & $\begin{array}{l}\text { TREE SPP } \\
\text { RICHNESS }\end{array}$ & $\begin{array}{c}\% \text { COVER } \\
\text { BLACKBERRY }\end{array}$ & $\begin{array}{c}\% \text { COVER } \\
\text { FORB }\end{array}$ & $\begin{array}{c}\% \text { COVER } \\
\text { CANOPY }\end{array}$ & $\begin{array}{c}\% \text { COVER } \\
\text { DOGWOOD }\end{array}$ & $\mathrm{CA}$ & $\mathrm{CC}$ & $\mathrm{PC}$ & $\mathrm{RC}$ & SC & SL & SR & $\mathrm{LOG}(\mathrm{L})$ & AIC & $\mathrm{K}$ & $\mathrm{AlC}_{\mathrm{c}}$ & $\Delta_{\mathrm{i}} \mathrm{AlCc}$ & L & $W_{i}$ \\
\hline 57 & -0.180 & 0.132 & 0.799 & 0.410 & 0.720 & -1.480 & NA & NA & NA & NA & NA & $\mathrm{NA}$ & NA & -80.878 & 175.756 & 7 & 177.029 & 0.000 & 1.000 & 0.147 \\
\hline 45 & -0.134 & 0.142 & 0.985 & NA & 0.696 & -1.513 & NA & NA & NA & NA & NA & NA & NA & -82.056 & 176.113 & 6 & 177.057 & 0.028 & 0.986 & 0.145 \\
\hline 62 & 0.726 & NA & 0.825 & 0.829 & 0.801 & -1.969 & -0.483 & -0.844 & -0.767 & -0.793 & -0.081 & -0.884 & -0.369 & -73.738 & 173.477 & 13 & 177.916 & 0.887 & 0.642 & 0.094 \\
\hline 53 & 0.485 & NA & 0.819 & 0.780 & 0.756 & NA & -0.553 & -0.900 & -0.495 & -0.544 & -0.001 & -0.581 & -0.112 & -75.675 & 175.350 & 12 & 179.109 & 2.080 & 0.353 & 0.052 \\
\hline 42 & -0.217 & 0.132 & 0.951 & 0.428 & 0.553 & NA & NA & NA & NA & NA & NA & NA & NA & -83.210 & 178.419 & 6 & 179.363 & 2.334 & 0.311 & 0.046 \\
\hline 24 & 0.185 & 0.153 & 1.068 & NA & NA & -1.141 & NA & NA & NA & NA & NA & NA & NA & -84.422 & 178.844 & 5 & 179.510 & 2.481 & 0.289 & 0.042 \\
\hline 23 & -0.169 & 0.142 & 1.149 & NA & 0.524 & NA & NA & NA & NA & NA & NA & NA & NA & -84.435 & 178.871 & 5 & 179.537 & 2.508 & 0.285 & 0.042 \\
\hline 63 & 0.529 & 0.049 & 0.833 & 0.818 & 0.793 & -2.003 & -0.517 & -0.726 & -0.740 & -0.756 & -0.154 & -0.886 & -0.370 & -73.185 & $174.370^{\prime}$ & ${ }^{\prime} 14$ & 179.555 & 2.526 & 0.283 & 0.042 \\
\hline 48 & -0.085 & 0.133 & NA & 0.613 & 0.805 & -1.779 & NA & NA & NA & NA & NA & NA & NA & -83.347 & 178.694 & 6 & 179.638 & 2.609 & 0.271 & 0.040 \\
\hline 56 & 0.832 & NA & NA & 0.854 & 0.913 & -1.952 & -0.483 & -0.931 & -0.677 & -0.936 & -0.132 & -0.701 & -0.333 & -76.040 & 176.080 & 12 & 179.839 & 2.810 & 0.245 & 0.036 \\
\hline 43 & 0.152 & 0.144 & 0.898 & 0.380 & NA & -1.099 & NA & NA & NA & NA & NA & NA & NA & -83.458 & 178.916 & 6 & 179.860 & 2.831 & 0.243 & 0.036 \\
\hline 7 & 0.093 & 0.151 & 1.183 & NA & NA & NA & NA & NA & NA & NA & NA & NA & NA & -85.808 & 179.615 & 4 & 180.055 & 3.026 & 0.220 & 0.032 \\
\hline 22 & 0.062 & 0.141 & 1.000 & 0.400 & NA & NA & NA & NA & NA & NA & NA & NA & NA & -84.767 & 179.535 & 5 & 180.201 & 3.172 & 0.205 & 0.030 \\
\hline 58 & 0.297 & 0.046 & 0.826 & 0.769 & 0.749 & NA & -0.586 & -0.791 & -0.465 & -0.505 & -0.068 & -0.578 & -0.108 & -75.209 & 176.418 & 13 & 180.857 & 3.828 & 0.148 & 0.022 \\
\hline 39 & 0.593 & NA & NA & 0.805 & 0.868 & NA & -0.553 & -0.986 & -0.409 & -0.688 & -0.052 & -0.401 & -0.078 & -77.857 & 177.715 & 11 & 180.858 & 3.829 & 0.147 & 0.022 \\
\hline 54 & 1.057 & NA & 0.983 & 0.756 & NA & -1.790 & -0.327 & -0.721 & -0.672 & -0.691 & 0.155 & -0.779 & -0.324 & -76.859 & 177.717 & 12 & 181.476 & 4.447 & 0.108 & 0.016 \\
\hline 61 & 0.645 & 0.047 & NA & 0.843 & 0.907 & -1.985 & -0.516 & -0.819 & -0.651 & -0.902 & -0.203 & -0.701 & -0.333 & -75 & 177.110 & 13 & 181.549 & 4.520 & 0.104 & 0.015 \\
\hline 55 & 0.803 & NA & 0.859 & NA & 0.729 & -1.776 & -0.192 & -0.829 & -0.554 & -0.719 & 0.075 & -0.349 & -0.231 & -76.901 & 177.802 & 12 & 181.561 & 4.532 & 0.104 & 0.015 \\
\hline 34 & 0.820 & NA & 0.970 & 0.715 & NA & NA & -0.399 & -0.778 & -0.428 & -0.468 & 0.216 & -0.507 & -0.091 & -78.374 & 178.748 & 11 & 181.891 & 4.862 & 0.088 & 0.013 \\
\hline 36 & 0.580 & NA & 0.852 & NA & 0.693 & NA & -0.272 & -0.880 & -0.319 & -0.497 & 0.139 & -0.103 & -0.005 & -78.393 & 178.786 & 11 & 181.929 & 4.900 & 0.086 & 0.013 \\
\hline 49 & 0.414 & 0.044 & NA & 0.794 & 0.862 & NA & -0.585 & -0.882 & -0.379 & -0.652 & -0.117 & -0.397 & -0.074 & -77.449 & 178.899 & 12 & 182.658 & 5.629 & 0.060 & 0.009 \\
\hline 29 & 0.030 & 0.150 & NA & NA & 0.798 & -1.953 & NA & NA & NA & NA & NA & NA & NA & -86.127 & 182.254 & 5 & 182.921 & 5.892 & 0.053 & 0.008 \\
\hline 59 & 0.846 & 0.052 & 0.990 & 0.745 & NA & -1.828 & -0.365 & -0.598 & -0.644 & -0.653 & 0.075 & -0.781 & -0.325 & -76.282 & 178.563 & 13 & 183.002 & 5.973 & 0.050 & 0.007 \\
\hline 60 & 0.590 & 0.053 & 0.867 & NA & 0.722 & -1.816 & -0.234 & -0.701 & -0.528 & -0.681 & -0.006 & -0.359 & -0.234 & -76.298 & 178.595 & 13 & 183.034 & 6.005 & 0.050 & 0.007 \\
\hline 46 & 0.375 & 0.050 & 0.859 & NA & 0.685 & NA & -0.312 & -0.761 & -0.289 & -0.456 & 0.064 & -0.106 & -0.002 & -77.873 & 179.747 & 12 & 183.506 & 6.477 & 0.039 & 0.006 \\
\hline 44 & 0.617 & 0.049 & 0.976 & 0.704 & NA & NA & -0.436 & -0.663 & -0.397 & -0.428 & 0.142 & -0.504 & -0.087 & -77.878 & 179.755 & 12 & 183.514 & 6.485 & 0.039 & 0.006 \\
\hline 27 & 0.305 & 0.146 & NA & 0.608 & NA & -1.388 & NA & NA & NA & NA & NA & NA & NA & -86.441 & 182.882 & 5 & 183.549 & 6.520 & 0.038 & 0.006 \\
\hline 41 & 0.916 & NA & NA & NA & 0.844 & -1.753 & -0.184 & -0.919 & -0.454 & -0.866 & 0.026 & -0.142 & -0.189 & -79.238 & 180.475 & 11 & 183.618 & 6.589 & 0.037 & 0.005 \\
\hline 15 & 0.882 & NA & 0.988 & NA & NA & NA & -0.152 & -0.769 & -0.270 & -0.431 & 0.328 & -0.071 & 0.006 & -80.560 & 181.119 & 10 & 183.707 & 6.678 & 0.035 & 0.005 \\
\hline 20 & 0.696 & NA & NA & NA & 0.807 & NA & -0.263 & -0.969 & -0.223 & -0.646 & 0.090 & 0.100 & 0.034 & -80.624 & 181.247 & 10 & 183.836 & 6.807 & 0.033 & 0.005 \\
\hline 37 & 1.101 & NA & 1.001 & NA & NA & -1.628 & -0.073 & -0.717 & -0.484 & -0.632 & 0.278 & -0.295 & -0.201 & -79.360 & 180.720 & 11 & 183.862 & 6.833 & 0.033 & 0.005 \\
\hline 26 & -0.109 & 0.132 & NA & 0.684 & 0.616 & NA & NA & NA & NA & NA & NA & NA & NA & -86.642 & 183.284 & 5 & 183.950 & 6.921 & 0.031 & 0.005 \\
\hline 40 & 1.244 & NA & NA & 0.773 & NA & -1.739 & -0.301 & -0.806 & -0.546 & -0.849 & 0.132 & -0.536 & -0.271 & -79.979 & 181.958 & 11 & 185.101 & 8.072 & 0.018 & 0.003 \\
\hline 51 & 0.712 & 0.051 & NA & NA & 0.838 & -1.791 & -0.224 & -0.797 & -0.428 & -0.830 & -0.052 & -0.149 & -0.191 & -78.705 & 181.410 & 12 & 185.169 & 8.140 & 0.017 & 0.003 \\
\hline 25 & 0.664 & 0.052 & 0.994 & NA & NA & NA & -0.195 & -0.646 & -0.240 & -0.389 & 0.248 & -0.075 & 0.008 & -80.016 & 182.032 & 11 & 185.175 & 8.146 & 0.017 & 0.002 \\
\hline 18 & 1.012 & NA & NA & 0.733 & NA & NA & -0.371 & -0.861 & -0.311 & -0.630 & 0.192 & -0.275 & -0.046 & -81.322 & 182.645 & 10 & 185.233 & 8.204 & 0.017 & 0.002 \\
\hline 47 & 0.876 & 0.055 & 1.008 & NA & NA & -1.671 & -0.117 & -0.585 & -0.457 & -0.592 & 0.192 & -0.306 & -0.204 & -78.739 & 181.478 & 12 & 185.237 & 8.208 & 0.017 & 0.002 \\
\hline
\end{tabular}


TABLE E1 continued. Summary of all 63 models tested for Black-headed Grosbeak, including model terms, number of parameters (K), log likelihood value, $A I C$ and $A I C_{c}$ scores, change in $A_{C} C_{c}$ score $\left(A I C_{c}\right)$ between models, likelihood value $(L)$ and $A I C_{c}$ weight $\left(W_{i}\right)$.

\begin{tabular}{|c|c|c|c|c|c|c|c|c|c|c|c|c|c|c|c|c|c|c|c|c|}
\hline MODEL & C & $\mathrm{R}$ & RY & FORB & CANOPY & DOGWOOD & $\mathrm{CA}$ & $\mathrm{CC}$ & PC & $\mathrm{RC}$ & sc & SL & SR & LOG(L) & AIC & $\mathrm{K}$ & $\mathrm{AlC}_{\mathrm{c}}$ & $\Delta_{\mathrm{i}} \mathrm{AlCc}$ & $\mathrm{L}$ & $W_{i}$ \\
\hline 8 & 0.210 & 0.143 & NA & 0.667 & NA & NA & NA & NA & NA & NA & NA & $\mathrm{NA}$ & NA & -88.451 & 184.903 & 4 & 185.342 & 8.313 & 0.016 & 0.002 \\
\hline 30 & 0.499 & 0.048 & NA & NA & 0.801 & NA & -0.301 & -0.856 & -0.194 & -0.607 & 0.018 & 0.098 & 0.037 & -80.165 & 182.330 & 11 & 185.473 & 8.444 & 0.015 & 0.002 \\
\hline 52 & 0.220 & NA & 0.809 & 0.571 & 0.867 & -1.471 & NA & NA & NA & NA & NA & NA & NA & -86.618 & 185.235 & 6 & 186.179 & 9.150 & 0.010 & 0.002 \\
\hline 10 & 0.416 & 0.163 & NA & NA & NA & -1.564 & NA & NA & NA & NA & NA & NA & NA & -89.007 & 186.013 & 4 & 186.453 & 9.424 & 0.009 & 0.001 \\
\hline 50 & 1.043 & 0.050 & NA & 0.763 & NA & -1.775 & -0.337 & -0.688 & -0.518 & -0.813 & 0.056 & -0.537 & -0.272 & -79.479 & 182.959 & 12 & 186.718 & 9.689 & 0.008 & 0.001 \\
\hline 28 & 0.817 & 0.047 & NA & 0.723 & NA & NA & -0.407 & -0.751 & -0.280 & -0.593 & 0.121 & -0.271 & -0.042 & -80.891 & 183.782 & 11 & 186.925 & 9.896 & 0.007 & 0.001 \\
\hline 6 & 1.079 & NA & NA & NA & NA & NA & -0.117 & -0.853 & -0.147 & -0.595 & 0.307 & 0.177 & 0.055 & -83.486 & 184.972 & 9 & 187.065 & 10.036 & 0.007 & 0.001 \\
\hline 21 & 1.293 & NA & NA & NA & NA & -1.573 & -0.040 & -0.803 & -0.351 & -0.791 & 0.258 & -0.037 & -0.144 & -82.434 & 184.868 & 10 & 187.456 & 10.427 & 0.005 & 0.001 \\
\hline 32 & 0.182 & NA & 0.960 & 0.589 & 0.701 & NA & NA & NA & $\mathrm{NA}$ & NA & NA & NA & NA & -88.666 & 187.332 & 5 & 187.998 & 10.969 & 0.004 & 0.001 \\
\hline 35 & 0.330 & NA & 1.077 & NA & 0.849 & -1.517 & NA & NA & NA & NA & NA & NA & NA & -88.690 & 187.380 & 5 & 188.047 & 11.018 & 0.004 & 0.001 \\
\hline 9 & 0.018 & 0.152 & NA & NA & 0.588 & NA & NA & NA & NA & NA & NA & NA & NA & -89.896 & 187.793 & 4 & 188.232 & 11.203 & 0.004 & 0.001 \\
\hline 38 & 0.317 & NA & NA & 0.778 & 0.954 & -1.773 & NA & NA & NA & NA & NA & NA & NA & -88.868 & 187.737 & 5 & 188.403 & 11.374 & 0.003 & 0.000 \\
\hline 11 & 0.869 & 0.050 & NA & NA & NA & NA & -0.159 & -0.735 & -0.117 & -0.555 & 0.229 & 0.174 & 0.057 & -83.010 & 186.019 & 10 & 188.607 & 11.578 & 0.003 & 0.000 \\
\hline 31 & 1.077 & 0.053 & NA & NA & NA & -1.614 & -0.083 & -0.677 & -0.325 & -0.754 & 0.175 & -0.045 & -0.147 & -81.892 & 185.784 & 11 & 188.927 & 11.898 & 0.003 & 0.000 \\
\hline 1 & 0.321 & 0.162 & NA & NA & NA & NA & NA & NA & NA & NA & NA & NA & NA & -91.442 & 188.885 & 3 & 189.146 & 12.117 & 0.002 & 0.000 \\
\hline 13 & 0.295 & NA & 1.242 & NA & 0.677 & NA & NA & NA & NA & NA & NA & NA & NA & -90.779 & 189.557 & 4 & 189.997 & 12.968 & 0.002 & 0.000 \\
\hline 12 & 0.581 & NA & 1.024 & 0.568 & NA & NA & NA & NA & NA & NA & NA & NA & NA & -90.930 & 189.860 & 4 & 190.300 & 13.271 & 0.001 & 0.000 \\
\hline 33 & 0.671 & NA & 0.931 & 0.552 & NA & -1.001 & NA & NA & NA & NA & NA & NA & NA & -89.976 & 189.952 & 5 & 190.618 & 13.589 & 0.001 & 0.000 \\
\hline 2 & 0.677 & NA & 1.294 & $N A$ & NA & NA & NA & NA & NA & NA & NA & NA & NA & -92.809 & 191.618 & 3 & 191.879 & 14.850 & 0.001 & 0.000 \\
\hline 14 & 0.769 & NA & 1.188 & NA & NA & -1.056 & NA & NA & NA & NA & NA & NA & NA & -91.787 & 191.574 & 4 & 192.013 & 14.984 & 0.001 & 0.000 \\
\hline 16 & 0.293 & NA & NA & 0.848 & 0.766 & NA & NA & NA & NA & NA & NA & NA & NA & -91.796 & 191.593 & 4 & 192.033 & 15.004 & 0.001 & 0.000 \\
\hline 17 & 0.839 & NA & NA & 0.791 & NA & -1.300 & NA & NA & NA & NA & NA & NA & NA & -92.785 & 193.569 & 4 & 194.009 & 16.980 & 0.000 & 0.000 \\
\hline 19 & 0.538 & NA & NA & NA & 0.971 & -2.000 & NA & NA & NA & NA & NA & NA & NA & -92.944 & 193.888 & 4 & 194.328 & 17.299 & 0.000 & 0.000 \\
\hline 3 & 0.740 & NA & NA & 0.844 & NA & NA & NA & NA & NA & NA & NA & NA & NA & -94.339 & 194.678 & 3 & 194.939 & 17.910 & 0.000 & 0.000 \\
\hline 4 & 0.534 & NA & NA & NA & 0.758 & NA & NA & NA & NA & NA & NA & NA & NA & -96.388 & 198.777 & 3 & 199.038 & 22.009 & 0.000 & 0.000 \\
\hline 5 & 1.073 & NA & NA & NA & NA & -1.523 & NA & NA & NA & NA & NA & NA & NA & -96.681 & 199.362 & 3 & 199.622 & 22.593 & 0.000 & 0.000 \\
\hline
\end{tabular}


TABLE E2. Summary of all 63 models tested for Orange-crowned Warbler, including model terms, number of parameters (K), log likelihood value, AIC and AICc scores, change in AICc score ( AICc) between models, likelihood value (L) and AICc weight (Wi).

$$
\text { SHRUB }
$$

$\%$ COVER CORRIDOR SPECIES \% COVER \% COVER

\begin{tabular}{lllllllllllllllllll} 
MODEL CONSTANT & SHRUB & WIDTH & RICHNESS DOGWOOD & COTTONWOOD & CA & CC & PC & RC & SC & SL & SR & LOG(L) & AIC & K & AIC & $\Delta_{i}$ AICC & L & W $_{i}$ \\
\hline
\end{tabular}

\begin{tabular}{|c|c|c|c|c|c|c|c|c|c|c|c|c|c|c|c|c|c|c|c|}
\hline 6 & 0.665 & NA & $\mathrm{NA}$ & NA & NA & $\mathrm{NA}$ & 0.111 & 1.158 & 0.510 & -0.181 & 0.888 & 0.553 & 0.154 & -75.539 & 169.079 & 91 & 171.172 & 0.000 & $1.000 \quad 0.137$ \\
\hline 21 & 0.804 & NA & NA & NA & NA & -0.068 & -0.022 & 1.019 & 0.376 & -0.320 & 0.750 & 0.414 & 0.021 & -74.556 & 169.112 & 101 & 171.700 & 0.528 & 0.7680 .105 \\
\hline 11 & 0.374 & 0.372 & NA & NA & NA & NA & 0.241 & 1.119 & 0.654 & -0.071 & 0.973 & 0.673 & 0.229 & -74.748 & 169.496 & 101 & 172.084 & 0.912 & 0.6340 .087 \\
\hline 31 & 0.508 & 0.382 & NA & NA & NA & -0.069 & 0.109 & 0.975 & 0.521 & -0.210 & 0.834 & 0.535 & 0.095 & -73.701 & 169.401 & 111 & 172.544 & 1.372 & 0.5040 .069 \\
\hline 15 & 0.328 & NA & 0.002 & NA & NA & NA & 0.254 & 1.383 & 0.711 & 0.007 & 1.145 & 0.749 & 0.352 & -75.027 & 170.054 & 101 & 172.642 & 1.470 & 0.4800 .066 \\
\hline 25 & -0.093 & 0.433 & 0.002 & NA & NA & NA & 0.440 & 1.391 & 0.927 & 0.181 & 1.306 & 0.936 & 0.487 & -73.966 & 169.931 & 111 & 173.074 & 1.902 & 0.3860 .053 \\
\hline 18 & 0.752 & NA & NA & -0.018 & NA & NA & 0.152 & 1.212 & 0.510 & -0.152 & 0.956 & 0.547 & 0.166 & -75.406 & 170.812 & 101 & 173.400 & 2.228 & 0.3280 .045 \\
\hline 20 & 0.673 & NA & NA & NA & -0.057 & NA & 0.114 & 1.160 & 0.503 & -0.188 & 0.886 & 0.545 & 0.147 & -75.538 & 171.075 & 101 & 173.664 & 2.492 & 0.2880 .039 \\
\hline 37 & 0.532 & NA & 0.001 & NA & NA & -0.061 & 0.102 & 1.206 & 0.544 & -0.161 & 0.962 & 0.579 & 0.187 & -74.261 & 170.522 & 111 & 173.665 & 2.493 & 0.2870 .039 \\
\hline 40 & 0.889 & NA & NA & -0.017 & NA & -0.068 & 0.019 & 1.073 & 0.377 & -0.292 & 0.818 & 0.409 & 0.032 & -74.426 & 170.852 & 111 & 173.995 & 2.823 & 0.2440 .033 \\
\hline 47 & 0.112 & 0.431 & 0.002 & NA & NA & -0.060 & 0.288 & 1.216 & 0.760 & 0.012 & 1.123 & 0.766 & 0.322 & -73.194 & 170.388 & 121 & 174.147 & 2.975 & $0.226 \quad 0.031$ \\
\hline 28 & 0.469 & 0.392 & NA & -0.022 & NA & NA & 0.300 & 1.185 & 0.662 & -0.029 & 1.064 & 0.672 & 0.247 & -74.533 & 171.065 & 111 & 174.208 & 3.036 & 0.2190 .030 \\
\hline 41 & 0.806 & NA & NA & NA & -0.014 & -0.068 & -0.021 & 1.020 & 0.375 & -0.322 & 0.750 & 0.413 & 0.019 & -74.556 & 171.112 & 111 & 174.255 & 3.083 & $0.214 \quad 0.029$ \\
\hline 30 & 0.402 & 0.389 & NA & NA & -0.308 & NA & 0.262 & 1.126 & 0.621 & -0.104 & 0.967 & 0.637 & 0.194 & -74.702 & 171.403 & 111 & 174.546 & 3.374 & 0.1850 .025 \\
\hline 50 & 0.601 & 0.402 & NA & -0.022 & NA & -0.069 & 0.167 & 1.041 & 0.529 & -0.169 & 0.925 & 0.534 & 0.113 & -73.486 & 170.972 & 121 & 174.731 & 3.559 & 0.1690 .023 \\
\hline 34 & 0.415 & NA & 0.002 & -0.020 & NA & NA & 0.306 & 1.453 & 0.719 & 0.047 & 1.233 & 0.750 & 0.372 & -74.854 & 171.708 & 111 & 174.851 & 3.679 & 0.1590 .022 \\
\hline 51 & 0.532 & 0.398 & NA & NA & -0.269 & -0.069 & 0.128 & 0.983 & 0.493 & -0.239 & 0.830 & 0.504 & 0.064 & -73.664 & 171.329 & 121 & 175.088 & 3.916 & 0.1410 .019 \\
\hline 44 & -0.006 & 0.460 & 0.002 & -0.026 & NA & NA & 0.519 & 1.483 & 0.951 & 0.243 & 1.431 & 0.949 & 0.522 & -73.668 & 171.335 & 121 & 175.094 & 3.922 & 0.1410 .019 \\
\hline 36 & 0.309 & NA & 0.002 & NA & 0.103 & NA & 0.251 & 1.384 & 0.728 & 0.023 & 1.152 & 0.766 & 0.368 & -75.022 & 172.043 & 111 & 175.186 & 4.014 & 0.1340 .018 \\
\hline 46 & -0.072 & 0.441 & 0.002 & NA & -0.149 & NA & 0.447 & 1.391 & 0.907 & 0.161 & 1.299 & 0.914 & 0.466 & -73.955 & 171.909 & 121 & 175.668 & 4.496 & $0.106 \quad 0.014$ \\
\hline 39 & 0.759 & NA & NA & -0.017 & -0.053 & NA & 0.155 & 1.214 & 0.504 & -0.159 & 0.955 & 0.540 & 0.159 & -75.405 & 172.809 & 111 & 175.952 & 4.780 & 0.0920 .013 \\
\hline 54 & 0.612 & NA & 0.001 & -0.019 & NA & -0.060 & 0.153 & 1.275 & 0.553 & -0.122 & 1.048 & 0.581 & 0.208 & -74.101 & 172.202 & 121 & 175.961 & 4.789 & 0.0910 .012 \\
\hline 59 & 0.193 & 0.457 & 0.002 & -0.025 & NA & -0.060 & 0.366 & 1.307 & 0.785 & 0.075 & 1.246 & 0.781 & 0.358 & -72.913 & 171.825 & 131 & 176.264 & 5.092 & $0.078 \quad 0.011$ \\
\hline 55 & 0.512 & NA & 0.001 & NA & 0.105 & -0.061 & 0.099 & 1.206 & 0.561 & -0.145 & 0.969 & 0.596 & 0.203 & -74.256 & 172.511 & 121 & 176.270 & 5.098 & 0.0780 .011 \\
\hline 56 & 0.890 & NA & NA & -0.017 & -0.010 & -0.068 & 0.019 & 1.073 & 0.375 & -0.293 & 0.818 & 0.408 & 0.031 & -74.426 & 172.852 & 121 & 176.611 & 5.439 & 0.0660 .009 \\
\hline 49 & 0.498 & 0.410 & NA & -0.022 & -0.316 & NA & 0.322 & 1.193 & 0.628 & -0.063 & 1.059 & 0.635 & 0.211 & -74.484 & 172.968 & 121 & 176.727 & 5.555 & 0.0620 .009 \\
\hline 60 & 0.132 & 0.438 & 0.002 & NA & -0.146 & -0.060 & 0.295 & 1.215 & 0.740 & -0.007 & 1.116 & 0.745 & 0.301 & -73.184 & 172.367 & 131 & 176.806 & 5.634 & 0.0600 .008 \\
\hline 61 & 0.626 & 0.418 & NA & -0.022 & -0.277 & -0.069 & 0.187 & 1.049 & 0.500 & -0.198 & 0.922 & 0.502 & 0.082 & -73.448 & 172.895 & 131 & 177.334 & 6.162 & 0.0460 .006 \\
\hline 53 & 0.393 & NA & 0.002 & -0.020 & 0.114 & NA & 0.303 & 1.454 & 0.737 & 0.064 & 1.241 & 0.768 & 0.390 & -74.848 & 173.695 & 121 & 177.454 & 6.282 & 0.0430 .006 \\
\hline 58 & 0.015 & 0.468 & 0.002 & -0.026 & -0.150 & NA & 0.527 & 1.483 & 0.930 & 0.223 & 1.423 & 0.927 & 0.501 & -73.657 & 173.313 & 13 & 177.752 & 6.580 & 0.0370 .005 \\
\hline 62 & 0.591 & NA & 0.001 & -0.019 & 0.115 & -0.060 & 0.150 & 1.275 & 0.572 & -0.104 & 1.056 & 0.600 & 0.226 & -74.094 & 174.189 & 131 & 178.628 & 7.456 & 0.0240 .003 \\
\hline 63 & 0.213 & 0.464 & 0.002 & -0.025 & -0.147 & -0.059 & 0.373 & 1.307 & 0.765 & 0.055 & 1.239 & 0.760 & 0.337 & -72.902 & $173.804^{\prime}$ & 14 & 178.989 & 7.817 & 0.0200 .003 \\
\hline 24 & 0.923 & 0.690 & -0.002 & NA & NA & -0.100 & NA & NA & NA & NA & NA & NA & NA & -91.429 & 192.858 & 51 & 193.525 & 22.353 & 0.0000 .000 \\
\hline 45 & 0.942 & 0.554 & -0.002 & NA & 1.053 & -0.104 & NA & NA & NA & NA & NA & NA & NA & -90.478 & 192.955 & 61 & 193.899 & 22.727 & 0.0000 .000 \\
\hline 10 & 0.705 & 0.713 & NA & NA & NA & -0.112 & NA & NA & NA & NA & NA & NA & NA & -92.940 & 193.880 & 41 & 194.319 & 23.147 & 0.0000 .000 \\
\hline 43 & 0.724 & 0.628 & -0.002 & 0.033 & NA & -0.096 & NA & NA & NA & NA & NA & NA & NA & -90.856 & 193.712 & 6 & 194.656 & 23.484 & 0.0000 .000 \\
\hline 7 & 0.968 & 0.634 & -0.003 & NA & NA & NA & NA & NA & NA & NA & NA & NA & NA & -93.131 & 194.263 & 41 & 194.702 & 23.530 & 0.0000 .000 \\
\hline 27 & 0.486 & 0.631 & NA & 0.041 & NA & -0.106 & NA & NA & NA & NA & NA & NA & NA & -92.024 & 194.048 & 51 & 194.714 & 23.542 & 0.0000 .000 \\
\hline 29 & 0.714 & 0.587 & NA & NA & 0.977 & -0.117 & NA & NA & NA & NA & NA & NA & NA & -92.145 & 194.291 & 51 & 194.957 & 23.785 & 0.0000 .000 \\
\hline 35 & 1.235 & NA & -0.002 & NA & 1.555 & -0.095 & NA & NA & NA & NA & NA & NA & NA & -92.303 & 194.606 & 5 & 195.273 & 24.101 & 0.0000 .000 \\
\hline 23 & 0.987 & 0.506 & -0.003 & NA & 0.972 & NA & NA & NA & NA & NA & NA & NA & NA & -92.348 & 194.696 & 51 & 195.362 & 24.190 & 0.0000 .000 \\
\hline
\end{tabular}


TABLE E2 continued. Summary of all 63 models tested for Orange-crowned Warbler with AIC $_{\mathrm{c}}$ values $<2.0$, including model terms, number of parameters $(K)$, log likelihood value, $A I C$ and $\mathrm{AIC}_{\mathrm{c}}$ scores, change in $\mathrm{AIC}_{\mathrm{c}}$ score $\left(\mathrm{AIC}_{\mathrm{c}}\right)$ between models, likelihood value $(\mathrm{L})$ and $\mathrm{AlC}_{c}$ weight $\left(\mathrm{W}_{\mathrm{i}}\right)$.

\begin{tabular}{|c|c|c|c|c|c|c|c|c|c|c|c|c|c|c|c|c|c|c|c|c|}
\hline MODEL & CONSTANT & $\begin{array}{c}\% \text { COVER } \\
\text { SHRUB }\end{array}$ & $\begin{array}{c}\text { CORRIDOR } \\
\text { WIDTH }\end{array}$ & $\begin{array}{c}\text { SHRUB } \\
\text { SPECIES } \\
\text { RICHNESS }\end{array}$ & $\begin{array}{c}\% \text { COVER } \\
\text { DOGWOOD }\end{array}$ & $\begin{array}{c}\text { \% COVER } \\
\text { COTTONWOOD }\end{array}$ & $\mathrm{CA}$ & $\mathrm{CC}$ & PC & $\mathrm{RC}$ & SC & SL & SR & LOG(L) & AIC & $\mathrm{K}$ & $\mathrm{AlC}_{\mathrm{c}}$ & $\Delta_{\mathrm{i}} \mathrm{AlCc}$ & L & $W_{i}$ \\
\hline 22 & 0.744 & 0.567 & -0.002 & 0.036 & $\mathrm{NA}$ & $\mathrm{NA}$ & $\mathrm{NA}$ & $\mathrm{NA}$ & $\mathrm{NA}$ & $\mathrm{NA}$ & $\mathrm{NA}$ & $\mathrm{NA}$ & $\mathrm{NA}$ & -92.441 & 194.881 & 5 & 195.548 & 24.376 & 0.000 & 0.000 \\
\hline 57 & 0.814 & 0.538 & -0.002 & 0.020 & 0.873 & -0.100 & $\mathrm{NA}$ & NA & NA & NA & NA & NA & NA & -90.278 & 194.557 & 7 & 195.829 & 24.657 & 0.000 & 0.000 \\
\hline 13 & 1.253 & NA & -0.003 & NA & 1.440 & NA & $\mathrm{NA}$ & NA & NA & NA & NA & NA & NA & -93.827 & 195.654 & 4 & 196.094 & 24.922 & 0.000 & 0.000 \\
\hline 48 & 0.541 & 0.559 & NA & 0.032 & 0.705 & -0.110 & NA & NA & NA & NA & NA & NA & NA & -91.652 & 195.303 & 6 & 196.247 & 25.075 & 0.000 & 0.000 \\
\hline 8 & 0.470 & 0.563 & NA & 0.047 & NA & NA & NA & NA & NA & NA & NA & NA & NA & -93.934 & 195.868 & 4 & 196.307 & 25.135 & 0.000 & 0.000 \\
\hline 1 & 0.721 & 0.651 & NA & NA & NA & NA & NA & NA & NA & NA & NA & NA & NA & -95.075 & 196.150 & 3 & 196.411 & 25.239 & 0.000 & 0.000 \\
\hline 19 & 1.011 & NA & NA & NA & 1.505 & -0.108 & $\mathrm{NA}$ & NA & NA & NA & NA & NA & NA & -94.129 & 196.258 & 4 & 196.698 & 25.526 & 0.000 & 0.000 \\
\hline 52 & 1.065 & NA & -0.002 & 0.026 & 1.311 & -0.091 & $\mathrm{NA}$ & NA & NA & NA & NA & NA & NA & -91.999 & 195.997 & 6 & 196.941 & 25.769 & 0.000 & 0.000 \\
\hline 42 & 0.822 & 0.488 & -0.002 & 0.026 & 0.745 & NA & NA & NA & NA & NA & NA & NA & NA & -92.031 & 196.063 & 6 & 197.006 & 25.834 & 0.000 & 0.000 \\
\hline 12 & 0.981 & NA & -0.002 & 0.049 & NA & NA & $\mathrm{NA}$ & $\mathrm{NA}$ & NA & NA & NA & NA & NA & -94.454 & 196.907 & 4 & 197.347 & 26.175 & 0.000 & 0.000 \\
\hline 9 & 0.729 & 0.537 & NA & NA & 0.872 & NA & $\mathrm{NA}$ & $\mathrm{NA}$ & NA & NA & NA & NA & NA & -94.469 & 196.938 & 4 & 197.377 & 26.205 & 0.000 & 0.000 \\
\hline 33 & 0.986 & NA & -0.002 & 0.047 & NA & -0.081 & $\mathrm{NA}$ & NA & NA & NA & NA & NA & NA & -93.359 & 196.719 & 5 & 197.385 & 26.213 & 0.000 & 0.000 \\
\hline 17 & 0.746 & NA & NA & 0.056 & NA & -0.091 & $\mathrm{NA}$ & NA & NA & NA & NA & NA & NA & -94.490 & 196.980 & 4 & 197.420 & 26.248 & 0.000 & 0.000 \\
\hline 32 & 1.050 & NA & -0.002 & 0.030 & 1.156 & NA & NA & NA & NA & NA & NA & NA & NA & -93.409 & 196.817 & 5 & 197.484 & 26.312 & 0.000 & 0.000 \\
\hline 14 & 1.325 & NA & -0.002 & NA & NA & -0.084 & $\mathrm{NA}$ & $\mathrm{NA}$ & NA & NA & NA & NA & NA & -94.534 & 197.069 & 4 & 197.508 & 26.336 & 0.000 & 0.000 \\
\hline 38 & 0.789 & NA & NA & 0.038 & 1.152 & -0.101 & $\mathrm{NA}$ & NA & NA & NA & NA & NA & NA & -93.454 & 196.907 & 5 & 197.574 & 26.402 & 0.000 & 0.000 \\
\hline 2 & 1.335 & NA & -0.003 & NA & NA & NA & $\mathrm{NA}$ & NA & NA & NA & NA & NA & NA & -95.703 & 197.406 & 3 & 197.667 & 26.495 & 0.000 & 0.000 \\
\hline 3 & 0.708 & NA & NA & 0.059 & NA & NA & NA & NA & NA & NA & NA & NA & NA & -95.859 & 197.717 & 3 & 197.978 & 26.806 & 0.000 & 0.000 \\
\hline 26 & 0.512 & 0.505 & NA & 0.040 & 0.539 & NA & NA & NA & NA & NA & NA & NA & NA & -93.723 & 197.446 & 5 & 198.113 & 26.941 & 0.000 & 0.000 \\
\hline 4 & 1.001 & NA & NA & NA & 1.365 & NA & $\mathrm{NA}$ & $\mathrm{NA}$ & NA & NA & NA & NA & NA & -96.067 & 198.133 & 3 & 198.394 & 27.222 & 0.000 & 0.000 \\
\hline 5 & 1.106 & NA & NA & NA & NA & -0.098 & $\mathrm{NA}$ & NA & NA & NA & NA & NA & NA & -96.149 & 198.299 & 3 & 198.560 & 27.388 & 0.000 & 0.000 \\
\hline 16 & 0.740 & NA & NA & 0.045 & 0.959 & NA & $\mathrm{NA}$ & $\mathrm{NA}$ & NA & NA & $\mathrm{NA}$ & NA & NA & -95.151 & 198.301 & 4 & 198.741 & 27.569 & 0.000 & 0.000 \\
\hline
\end{tabular}


TABLE E3. Summary of all 63 models tested for Pacific-slope Flycatcher, including model terms, number of parameters (K), log likelihood value, AIC and AICc scores, change in AICc score ( AICc) between models, likelihood value (L) and AICc weight (Wi).

TREE

$\%$ COVER SPECIES \% COVER \% COVER \% COVER

\begin{tabular}{|c|c|c|c|c|c|c|c|c|c|c|c|c|c|c|c|c|c|c|c|c|}
\hline MOL & INT & GRASS & RICHNESS & OAK & CANOPY & WILLOW & CA & $\mathrm{CC}$ & PC & $\mathrm{RC}$ & SC & SL & SR & LOG(L) & AIC & $\mathrm{K}$ & $\mathrm{AlC}_{\mathrm{c}}$ & $\Delta_{\mathrm{i}} \mathrm{AlCc}$ & L & $W_{i}$ \\
\hline 29 & 2.924 & -8.307 & $\mathrm{NA}$ & NA & 2.063 & -3.094 & NA & NA & $\mathrm{NA}$ & $\mathrm{NA}$ & $\mathrm{NA}$ & $\mathrm{NA}$ & $\mathrm{NA}$ & -184.385 & 378.770 & 5 & 379.437 & 0.000 & 1.000 & 0.151 \\
\hline 22 & 1.704 & -7.598 & 0.271 & 2.570 & NA & NA & NA & NA & NA & NA & NA & NA & NA & -184.395 & 378.789 & 5 & 379.456 & 0.019 & 0.991 & 0.150 \\
\hline 45 & 2.197 & -7.685 & 0.166 & NA & 1.807 & -2.526 & NA & NA & NA & NA & NA & NA & NA & -183.438 & 378.875 & 6 & 379.819 & 0.382 & 0.826 & 0.125 \\
\hline 43 & 2.331 & -8.090 & 0.227 & 1.993 & NA & -1.124 & NA & NA & NA & NA & NA & NA & NA & -183.876 & 379.752 & 6 & 380.696 & 1.259 & 0.533 & 0.081 \\
\hline 24 & 2.925 & -8.196 & 0.213 & NA & NA & -2.030 & NA & NA & NA & NA & NA & NA & NA & -185.306 & 380.612 & 5 & 381.278 & 1.841 & 0.398 & 0.060 \\
\hline 42 & 1.594 & -7.485 & 0.270 & 2.459 & 0.213 & NA & NA & NA & NA & NA & NA & NA & NA & -184.373 & 380.745 & 6 & 381.689 & 2.252 & 0.324 & 0.049 \\
\hline 48 & 2.927 & -8.337 & NA & 0.165 & 1.978 & -3.006 & NA & NA & NA & NA & NA & NA & NA & -184.380 & 380.759 & 6 & 381.703 & 2.266 & 0.322 & 0.049 \\
\hline 57 & 2.134 & -7.768 & 0.183 & 0.815 & 1.361 & -2.033 & NA & NA & NA & NA & NA & NA & NA & -183.309 & 380.617 & 7 & 381.890 & 2.453 & 0.293 & 0.044 \\
\hline 27 & 3.556 & -9.084 & NA & 1.833 & NA & -1.902 & NA & NA & NA & NA & NA & NA & NA & -185.684 & 381.367 & 5 & 382.034 & 2.597 & 0.273 & 0.041 \\
\hline 10 & 4.033 & -9.123 & NA & NA & NA & -2.694 & NA & NA & NA & NA & NA & NA & NA & -186.857 & 381.714 & 4 & 382.154 & 2.717 & 0.257 & 0.039 \\
\hline 8 & 2.800 & -8.502 & NA & 2.901 & NA & NA & NA & NA & NA & NA & NA & NA & NA & -187.319 & 382.638 & 4 & 383.078 & 3.641 & 0.162 & 0.025 \\
\hline 7 & 1.854 & -7.109 & 0.308 & NA & NA & NA & NA & NA & NA & NA & NA & NA & NA & -187.413 & 382.825 & 4 & 383.265 & 3.828 & 0.148 & 0.022 \\
\hline 23 & 1.196 & -6.592 & 0.292 & NA & 1.202 & NA & NA & NA & NA & NA & NA & NA & NA & -186.574 & 383.148 & 5 & 383.814 & 4.377 & 0.112 & 0.017 \\
\hline 26 & 2.614 & -8.314 & NA & 2.720 & 0.343 & NA & NA & NA & NA & NA & NA & NA & NA & -187.265 & 384.531 & 5 & 385.197 & 5.760 & 0.056 & 0.008 \\
\hline 47 & 2.428 & -6.784 & 0.255 & NA & NA & -2.326 & -0.604 & 1.295 & 0.470 & -0.482 & 1.133 & 0.544 & 0.088 & -179.004 & 382.008 & 12 & 385.767 & 6.330 & 0.042 & 0.006 \\
\hline 60 & 1.907 & -5.931 & 0.255 & NA & 1.744 & -3.198 & -1.106 & 1.151 & 0.279 & -0.867 & 0.462 & 0.330 & 0.028 & -177.693 & 381.387 & 13 & 385.826 & 6.389 & 0.041 & 0.006 \\
\hline 31 & 3.531 & -7.498 & NA & NA & NA & -2.444 & -0.356 & 0.735 & 0.392 & -0.610 & 1.521 & 0.553 & 0.087 & -180.586 & 383.172 & 11 & 386.314 & 6.877 & 0.032 & 0.005 \\
\hline 51 & 3.011 & -6.646 & NA & NA & 1.744 & -3.315 & -0.858 & 0.591 & 0.201 & -0.994 & 0.851 & 0.339 & 0.028 & -179.319 & 382.638 & 12 & 386.397 & 6.960 & 0.031 & 0.005 \\
\hline 44 & 1.222 & -5.418 & 0.330 & 2.703 & NA & NA & -1.058 & 0.855 & 0.046 & -0.676 & 0.683 & 0.557 & 0.125 & -179.331 & 382.661 & 12 & 386.420 & 6.983 & 0.030 & 0.005 \\
\hline 59 & 1.996 & -6.221 & 0.298 & 1.839 & NA & -1.741 & -1.022 & 1.137 & 0.271 & -0.756 & 0.643 & 0.501 & 0.117 & -178.174 & 382.349 & 13 & 386.788 & 7.351 & 0.025 & 0.004 \\
\hline 25 & 1.523 & -5.929 & 0.274 & NA & NA & NA & -0.350 & 0.966 & 0.261 & -0.153 & 1.561 & 0.665 & 0.081 & -181.381 & 384.763 & 11 & 387.905 & 8.468 & 0.014 & 0.002 \\
\hline 9 & 2.261 & -7.392 & NA & NA & 1.458 & NA & NA & NA & NA & NA & NA & NA & NA & -189.813 & 387.627 & 4 & 388.066 & 8.629 & 0.013 & 0.002 \\
\hline 1 & 3.139 & -8.079 & NA & NA & NA & NA & NA & NA & NA & NA & NA & NA & NA & -190.976 & 387.952 & 3 & 388.213 & 8.776 & 0.012 & 0.002 \\
\hline 50 & 3.375 & -7.218 & NA & 1.166 & NA & -2.086 & -0.595 & 0.574 & 0.257 & -0.797 & 1.252 & 0.527 & 0.105 & -180.247 & 384.493 & 12 & 388.252 & 8.815 & 0.012 & 0.002 \\
\hline 63 & 1.811 & -5.840 & 0.275 & 0.844 & 1.401 & -2.758 & -1.199 & 1.107 & 0.226 & -0.917 & 0.369 & 0.352 & 0.053 & -177.566 & 383.133 & 14 & 388.318 & 8.881 & 0.012 & 0.002 \\
\hline 11 & 2.667 & -6.655 & NA & NA & NA & NA & -0.068 & 0.343 & 0.165 & -0.272 & 2.004 & 0.681 & 0.080 & -183.131 & 386.262 & 10 & 388.850 & 9.413 & 0.009 & 0.001 \\
\hline 28 & 2.613 & -6.368 & NA & 2.134 & NA & NA & -0.582 & 0.155 & -0.021 & -0.705 & 1.382 & 0.600 & 0.115 & -181.863 & 385.726 & 11 & 388.869 & 9.432 & 0.009 & 0.001 \\
\hline 61 & 3.011 & -6.646 & NA & -0.008 & 1.747 & -3.319 & -0.857 & 0.592 & 0.202 & -0.993 & 0.852 & 0.339 & 0.027 & -179.319 & 384.638 & 13 & 389.077 & 9.640 & 0.008 & 0.001 \\
\hline 58 & 1.273 & -5.485 & 0.331 & 2.742 & -0.110 & NA & -1.042 & 0.870 & 0.060 & -0.667 & 0.703 & 0.567 & 0.130 & -179.325 & 384.649 & 13 & 389.088 & 9.651 & 0.008 & 0.001 \\
\hline 34 & 0.945 & NA & 0.395 & 3.056 & NA & NA & -1.590 & 0.821 & -0.444 & -1.418 & 0.342 & 0.528 & 0.048 & -182.144 & 386.287 & 11 & 389.430 & 9.993 & 0.007 & 0.001 \\
\hline 55 & 1.302 & NA & 0.317 & NA & 2.376 & -3.066 & -1.688 & 1.016 & -0.301 & -1.629 & 0.072 & 0.260 & -0.079 & -180.928 & 385.856 & 12 & 389.615 & 10.178 & 0.006 & 0.001 \\
\hline 12 & 1.129 & NA & 0.344 & 2.210 & NA & NA & NA & NA & NA & NA & NA & NA & NA & -190.736 & 389.471 & 4 & 389.911 & 10.474 & 0.005 & 0.001 \\
\hline 35 & 1.019 & NA & 0.258 & NA & 2.223 & -1.794 & NA & NA & NA & NA & NA & NA & NA & -189.630 & 389.259 & 5 & 389.926 & 10.489 & 0.005 & 0.001 \\
\hline 46 & 1.324 & -5.657 & 0.276 & NA & 0.405 & NA & -0.444 & 0.904 & 0.198 & -0.213 & 1.442 & 0.625 & 0.066 & -181.297 & 386.595 & 12 & 390.354 & 10.917 & 0.004 & 0.001 \\
\hline 13 & 0.401 & NA & 0.342 & NA & 1.731 & NA & NA & NA & NA & NA & NA & NA & NA & -191.104 & 390.209 & 4 & 390.648 & 11.211 & 0.004 & 0.001 \\
\hline 32 & 0.597 & NA & 0.332 & 1.656 & 1.114 & NA & NA & NA & NA & NA & NA & NA & NA & -190.171 & 390.342 & 5 & 391.009 & 11.572 & 0.003 & 0.000 \\
\hline 54 & 1.377 & NA & 0.381 & 2.576 & NA & -1.029 & -1.615 & 0.985 & -0.354 & -1.530 & 0.289 & 0.493 & 0.036 & -181.745 & 387.489 & 12 & 391.248 & 11.811 & 0.003 & 0.000 \\
\hline 30 & 2.500 & -6.423 & NA & NA & 0.350 & NA & -0.148 & 0.286 & 0.110 & -0.325 & 1.904 & 0.648 & 0.067 & -183.070 & 388.141 & 11 & 391.283 & 11.846 & 0.003 & 0.000 \\
\hline 49 & 2.643 & -6.407 & NA & 2.156 & -0.063 & NA & -0.572 & 0.163 & -0.013 & -0.700 & 1.394 & 0.605 & 0.117 & -181.861 & 387.722 & 12 & 391.481 & 12.044 & 0.002 & 0.000 \\
\hline 2 & 1.291 & NA & 0.371 & NA & NA & NA & NA & NA & NA & NA & NA & NA & NA & -192.730 & 391.460 & 3 & 391.721 & 12.284 & 0.002 & 0.000 \\
\hline
\end{tabular}


TABLE E3 continued. Summary of all 63 models tested for Pacific-slope Flycatcher, including model terms, number of parameters (K), log likelihood value, $\mathrm{AIC}$ and $\mathrm{AIC}_{c}$ scores, change in $\mathrm{AIC}_{c}$ score $\left(\mathrm{AIC}_{c}\right)$ between models, likelihood value $(\mathrm{L})$ and $\mathrm{AIC}$, weight $\left(\mathrm{W}_{\mathrm{i}}\right)$.

$$
\text { TREE }
$$

\% COVER SPECIES \% COVER \% COVER \% COVER

\begin{tabular}{|c|c|c|c|c|c|c|c|c|c|c|c|c|c|c|c|c|c|c|c|c|}
\hline ODE & & GRA & $\mathrm{CHN}$ & 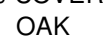 & CANOPY & WILLOW & $\mathrm{CA}$ & $\mathrm{CC}$ & PC & $\mathrm{RC}$ & SC & SL & SR & $\operatorname{LOG}(\mathrm{L})$ & AIC & $\mathrm{K}$ & $\mathrm{AlC}_{\mathrm{c}}$ & $\Delta_{\mathrm{i}} \mathrm{AlCc}$ & L & $W_{i}$ \\
\hline 37 & 1.924 & NA & 0.330 & NA & NA & -1.786 & -1.086 & 1.195 & -0.147 & -1.235 & 0.954 & 0.553 & -0.015 & -183.300 & 388.601 & 11 & 391.743 & 12.306 & 0.002 & 0.000 \\
\hline 53 & 0.732 & NA & 0.390 & 2.860 & 0.503 & NA & -1.631 & 0.754 & -0.480 & -1.418 & 0.272 & 0.488 & 0.032 & -182.016 & 388.031 & 12 & 391.790 & 12.353 & 0.002 & 0.000 \\
\hline 41 & 2.623 & NA & NA & NA & 2.473 & -3.196 & -1.460 & 0.277 & -0.491 & -1.911 & 0.509 & 0.262 & -0.097 & -183.332 & 388.663 & 11 & 391.806 & 12.369 & 0.002 & 0.000 \\
\hline 62 & 1.180 & NA & 0.343 & 1.178 & 1.884 & -2.455 & -1.805 & 0.957 & -0.364 & -1.683 & -0.050 & 0.293 & -0.042 & -180.695 & 387.391 & 13 & 391.830 & 12.393 & 0.002 & 0.000 \\
\hline 15 & 1.259 & NA & 0.338 & NA & NA & NA & -0.837 & 0.945 & -0.251 & -0.899 & 1.311 & 0.648 & -0.011 & -184.635 & 389.270 & 10 & 391.858 & 12.421 & 0.002 & 0.000 \\
\hline 19 & 2.050 & NA & NA & NA & 2.696 & -2.623 & NA & NA & NA & NA & NA & NA & NA & -191.725 & 391.450 & 4 & 391.889 & 12.452 & 0.002 & 0.000 \\
\hline 33 & 1.212 & NA & 0.338 & 2.125 & NA & -0.159 & NA & NA & NA & NA & NA & NA & NA & -190.726 & 391.452 & 5 & 392.119 & 12.682 & 0.002 & 0.000 \\
\hline 52 & 0.985 & NA & 0.267 & 0.363 & 2.026 & -1.570 & NA & NA & NA & NA & NA & NA & NA & -189.607 & 391.214 & 6 & 392.158 & 12.721 & 0.002 & 0.000 \\
\hline 14 & 1.830 & NA & 0.325 & NA & NA & -1.112 & NA & NA & NA & NA & NA & NA & NA & -192.137 & 392.274 & 4 & 392.714 & 13.277 & 0.001 & 0.000 \\
\hline 36 & 0.768 & NA & 0.335 & NA & 1.061 & NA & -1.026 & 0.785 & -0.353 & -0.968 & 1.030 & 0.547 & -0.038 & -184.047 & 390.094 & 11 & 393.237 & 13.800 & 0.001 & 0.000 \\
\hline 18 & 2.606 & NA & NA & 2.428 & NA & NA & -1.116 & -0.053 & -0.633 & -1.615 & 1.134 & 0.574 & 0.018 & -185.642 & 391.284 & 10 & 393.872 & 14.435 & 0.001 & 0.000 \\
\hline 38 & 2.052 & NA & NA & -0.665 & 3.029 & -2.984 & NA & NA & NA & NA & NA & NA & NA & -191.645 & 393.290 & 5 & 393.957 & 14.520 & 0.001 & 0.000 \\
\hline 21 & 3.327 & NA & NA & NA & NA & -1.867 & -0.823 & 0.432 & -0.339 & -1.511 & 1.448 & 0.567 & -0.031 & -185.778 & 391.556 & 10 & 394.144 & 14.707 & 0.001 & 0.000 \\
\hline 56 & 2.621 & NA & NA & 0.134 & 2.418 & -3.128 & -1.471 & 0.264 & -0.500 & -1.919 & 0.500 & 0.265 & -0.093 & -183.329 & 390.657 & 12 & 394.416 & 14.979 & 0.001 & 0.000 \\
\hline 6 & 2.667 & NA & NA & NA & NA & NA & -0.556 & 0.152 & -0.452 & -1.167 & 1.833 & 0.667 & -0.027 & -187.165 & 392.329 & 9 & 394.422 & 14.985 & 0.001 & 0.000 \\
\hline 40 & 3.094 & NA & NA & 1.833 & NA & -1.338 & -1.170 & 0.198 & -0.507 & -1.752 & 1.030 & 0.526 & 0.004 & -185.006 & 392.012 & 11 & 395.155 & 15.718 & 0.000 & 0.000 \\
\hline 20 & 2.142 & NA & NA & NA & 1.105 & NA & -0.755 & -0.007 & -0.557 & -1.236 & 1.537 & 0.562 & -0.055 & -186.560 & 393.121 & 10 & 395.709 & 16.272 & 0.000 & 0.000 \\
\hline 39 & 2.286 & NA & NA & 2.172 & 0.686 & NA & -1.181 & -0.130 & -0.678 & -1.611 & 1.024 & 0.519 & -0.004 & -185.419 & 392.839 & 11 & 395.981 & 16.544 & 0.000 & 0.000 \\
\hline 3 & 2.473 & NA & NA & 2.587 & NA & NA & NA & NA & NA & NA & NA & $\mathrm{NA}$ & NA & -194.932 & 395.864 & 3 & 396.124 & 16.687 & 0.000 & 0.000 \\
\hline 16 & 1.744 & NA & NA & 1.873 & 1.403 & NA & NA & NA & NA & NA & NA & NA & NA & -194.100 & 396.200 & 4 & 396.640 & 17.203 & 0.000 & 0.000 \\
\hline 4 & 1.561 & NA & NA & NA & 2.115 & NA & NA & NA & NA & NA & NA & NA & NA & -195.202 & 396.405 & 3 & 396.665 & 17.228 & 0.000 & 0.000 \\
\hline 5 & 3.429 & NA & NA & NA & NA & -2.022 & NA & NA & NA & NA & NA & NA & NA & -195.414 & 396.828 & 3 & 397.089 & 17.652 & 0.000 & 0.000 \\
\hline 17 & 2.938 & NA & NA & 1.896 & NA & -1.206 & NA & NA & NA & NA & NA & NA & NA & -194.364 & 396.728 & 4 & 397.167 & 17.730 & 0.000 & 0.000 \\
\hline
\end{tabular}


TABLE E4. Summary of all 63 models tested for Song Sparrow, including model terms, number of parameters (K), log likelihood value, QAIC and QAICc scores, change in QAICc score ( QAICC) between models, likelihood value (L) and AICc weight (Wi).

\begin{tabular}{|c|c|c|c|c|c|c|c|c|c|c|c|c|c|c|c|c|c|c|c|c|}
\hline MODEL & CONSTANT & $\begin{array}{c}\% \text { COVER } \\
\text { BLACKBERRY }\end{array}$ & ELEVATION & $\begin{array}{c}\% \text { COVER } \\
\text { FORB }\end{array}$ & $\begin{array}{c}\text { SHRUB } \\
\text { SPECIES } \\
\text { RICHNESS }\end{array}$ & $\begin{array}{c}\% \text { COVER } \\
\text { POISON } \\
\text { OAK }\end{array}$ & CA & CC & PC & $\mathrm{RC}$ & SC & SL & SR & LOG(L) & AIC & $\mathrm{K}$ & QAIC $_{c}$ & $\Delta_{\mathrm{i}} \mathrm{QAICC}$ & L & $W_{i}$ \\
\hline 1 & 3.281 & 6.422 & NA & NA & $\mathrm{NA}$ & NA & $\mathrm{NA}$ & NA & NA & NA & NA & $\mathrm{NA}$ & NA & -233.157 & 472.315 & 4 & 82.258 & 0.000 & 1.000 & 0.092 \\
\hline 2 & 5.757 & NA & -0.009 & NA & NA & NA & NA & NA & NA & NA & NA & NA & NA & -233.845 & 473.691 & 4 & 82.476 & 0.218 & 0.897 & 0.083 \\
\hline 12 & 4.645 & NA & -0.009 & 3.872 & NA & NA & NA & NA & NA & NA & NA & NA & NA & -228.345 & 464.691 & 5 & 82.962 & 0.704 & 0.703 & 0.065 \\
\hline 3 & 3.632 & NA & NA & 4.054 & NA & NA & NA & NA & NA & NA & NA & NA & NA & -235.544 & 477.088 & 4 & 83.014 & 0.756 & 0.685 & 0.063 \\
\hline 4 & 7.542 & NA & NA & NA & -0.434 & NA & NA & NA & NA & NA & NA & NA & NA & -235.648 & 477.297 & 4 & 83.047 & 0.789 & 0.674 & 0.062 \\
\hline 7 & 4.346 & 5.185 & -0.007 & NA & NA & NA & NA & NA & NA & NA & NA & NA & NA & -228.630 & 465.259 & 5 & 83.052 & 0.794 & 0.672 & 0.062 \\
\hline 10 & 4.142 & 6.089 & NA & NA & NA & -3.715 & NA & NA & NA & NA & NA & NA & NA & -230.778 & 469.556 & 5 & 83.732 & 1.474 & 0.479 & 0.044 \\
\hline 5 & 5.681 & NA & NA & NA & NA & -4.356 & NA & NA & NA & NA & NA & NA & NA & -237.927 & 481.853 & 4 & 83.768 & 1.510 & 0.470 & 0.043 \\
\hline 9 & 5.406 & 5.199 & NA & NA & -0.287 & NA & NA & NA & NA & NA & NA & NA & NA & -230.911 & 469.822 & 5 & 83.774 & 1.516 & 0.469 & 0.043 \\
\hline 8 & 2.831 & 5.155 & NA & 2.664 & NA & NA & NA & NA & NA & NA & NA & NA & NA & -230.927 & 469.854 & 5 & 83.779 & 1.521 & 0.467 & 0.043 \\
\hline 16 & 6.104 & NA & NA & 3.325 & -0.354 & NA & NA & NA & NA & NA & NA & NA & NA & -231.997 & 471.994 & 5 & 84.118 & 1.860 & 0.395 & 0.036 \\
\hline 13 & 7.026 & NA & -0.007 & NA & -0.236 & NA & NA & NA & NA & NA & NA & NA & NA & -232.623 & 473.247 & 5 & 84.316 & 2.058 & 0.357 & 0.033 \\
\hline 14 & 6.170 & NA & -0.008 & NA & NA & -2.516 & NA & NA & NA & NA & NA & NA & NA & -232.880 & 473.760 & 5 & 84.397 & 2.139 & 0.343 & 0.032 \\
\hline 22 & 3.905 & 3.758 & -0.007 & 2.886 & NA & NA & NA & NA & NA & NA & NA & NA & NA & -225.742 & 461.483 & 6 & 84.414 & 2.156 & 0.340 & 0.031 \\
\hline 19 & 7.959 & NA & NA & NA & -0.386 & -3.405 & NA & NA & NA & NA & NA & NA & NA & -233.808 & 475.616 & 5 & 84.691 & 2.433 & 0.296 & 0.027 \\
\hline 17 & 4.387 & NA & NA & 3.436 & NA & -2.762 & NA & NA & NA & NA & NA & NA & NA & -234.426 & 476.852 & 5 & 84.887 & 2.629 & 0.269 & 0.025 \\
\hline 24 & 4.753 & 5.145 & -0.006 & NA & NA & -2.413 & NA & NA & NA & NA & NA & NA & NA & -227.640 & 465.279 & 6 & 85.015 & 2.757 & 0.252 & 0.023 \\
\hline 32 & 5.399 & NA & -0.008 & 3.634 & -0.128 & NA & NA & NA & NA & NA & NA & NA & NA & -227.972 & 465.943 & 6 & 85.121 & 2.863 & 0.239 & 0.022 \\
\hline 33 & 4.798 & NA & -0.008 & 3.726 & NA & -0.676 & NA & NA & NA & NA & NA & NA & NA & -228.276 & 466.552 & 6 & 85.217 & 2.959 & 0.228 & 0.021 \\
\hline 23 & 5.091 & 4.846 & -0.006 & NA & -0.122 & NA & NA & NA & NA & NA & NA & NA & NA & -228.296 & 466.592 & 6 & 85.223 & 2.965 & 0.227 & 0.021 \\
\hline 26 & 4.788 & 4.183 & NA & 2.394 & -0.258 & NA & NA & NA & NA & NA & NA & NA & NA & -229.055 & 468.109 & 6 & 85.463 & 3.205 & 0.201 & 0.019 \\
\hline 29 & 5.846 & 5.087 & NA & NA & -0.246 & -3.215 & NA & NA & NA & NA & NA & NA & NA & -229.103 & 468.206 & 6 & 85.479 & 3.221 & 0.200 & 0.018 \\
\hline 27 & 3.609 & 5.210 & NA & 2.006 & NA & -2.877 & NA & NA & NA & NA & NA & NA & NA & -229.589 & 469.178 & 6 & 85.633 & 3.375 & 0.185 & 0.017 \\
\hline 38 & 6.569 & NA & NA & 2.874 & -0.334 & -2.201 & NA & NA & NA & NA & NA & NA & NA & -231.247 & 472.494 & 6 & 86.158 & 3.900 & 0.142 & 0.013 \\
\hline 35 & 7.401 & NA & -0.006 & NA & -0.231 & -2.447 & NA & NA & NA & NA & NA & NA & NA & -231.688 & 473.375 & 6 & 86.297 & 4.039 & 0.133 & 0.012 \\
\hline 43 & 4.142 & 3.877 & -0.007 & 2.608 & NA & -1.151 & NA & NA & NA & NA & NA & NA & NA & -225.532 & 463.064 & 7 & 86.677 & 4.419 & 0.110 & 0.010 \\
\hline 42 & 4.329 & 3.615 & -0.007 & 2.799 & -0.067 & NA & NA & NA & NA & NA & NA & NA & NA & -225.637 & 463.274 & 7 & 86.710 & 4.452 & 0.108 & 0.010 \\
\hline 45 & 5.467 & 4.819 & -0.005 & NA & -0.117 & -2.385 & NA & NA & NA & NA & NA & NA & NA & -227.323 & 466.647 & 7 & 87.244 & 4.986 & 0.083 & 0.008 \\
\hline 52 & 5.593 & NA & -0.007 & 3.462 & -0.131 & -0.767 & NA & NA & NA & NA & NA & NA & NA & -227.882 & 467.764 & 7 & 87.421 & 5.163 & 0.076 & 0.007 \\
\hline 48 & 5.264 & 4.326 & NA & 1.856 & -0.233 & -2.466 & NA & NA & NA & NA & NA & NA & NA & -228.055 & 468.109 & 7 & 87.476 & 5.218 & 0.074 & 0.007 \\
\hline 57 & 4.594 & 3.729 & -0.006 & 2.508 & -0.070 & -1.182 & NA & NA & NA & NA & NA & NA & NA & -225.416 & 464.832 & 8 & 89.023 & 6.765 & 0.034 & 0.003 \\
\hline 6 & 3.833 & NA & NA & NA & NA & NA & 0.722 & 0.803 & 2.167 & -3.333 & -0.476 & 3.944 & 1.647 & -220.233 & 458.466 & 10 & 92.315 & 10.057 & 0.007 & 0.001 \\
\hline 20 & 5.031 & NA & NA & NA & -0.240 & NA & 1.281 & 1.543 & 2.167 & -2.944 & 0.465 & 3.865 & 1.800 & -218.994 & 457.988 & 11 & 94.477 & 12.219 & 0.002 & 0.000 \\
\hline 15 & 5.579 & NA & -0.018 & NA & NA & NA & 4.245 & 0.245 & 0.833 & -2.128 & 3.757 & 2.305 & 0.311 & -219.321 & 458.643 & 11 & 94.581 & 12.323 & 0.002 & 0.000 \\
\hline 21 & 5.065 & NA & NA & NA & NA & -2.353 & 0.035 & -0.019 & 1.376 & -4.151 & -0.969 & 2.899 & 0.793 & -219.472 & 458.944 & 11 & 94.629 & 12.371 & 0.002 & 0.000 \\
\hline 11 & 3.492 & 1.711 & NA & NA & NA & NA & 0.662 & 0.948 & 1.952 & -3.049 & -0.439 & 3.515 & 1.562 & -219.737 & 459.474 & 11 & 94.713 & 12.455 & 0.002 & 0.000 \\
\hline 18 & 3.700 & NA & NA & 1.452 & NA & NA & 0.218 & 0.788 & 1.842 & -3.403 & -0.704 & 3.050 & 1.447 & -219.750 & 459.500 & 11 & 94.717 & 12.459 & 0.002 & 0.000 \\
\hline 36 & 7.047 & NA & -0.020 & NA & -0.258 & NA & 5.207 & 0.986 & 0.697 & -1.585 & 5.203 & 2.052 & 0.339 & -217.863 & 457.726 & 12 & 96.735 & 14.477 & 0.001 & 0.000 \\
\hline 41 & 5.990 & NA & NA & NA & -0.220 & -2.019 & 0.646 & 0.777 & 1.488 & -3.678 & -0.036 & 2.974 & 1.055 & -218.429 & 458.857 & 12 & 96.914 & 14.656 & 0.001 & 0.000 \\
\hline 37 & 6.667 & NA & -0.018 & NA & NA & -2.227 & 3.439 & -0.508 & 0.144 & -2.955 & 3.102 & 1.388 & -0.438 & -218.629 & 459.258 & 12 & 96.978 & 14.720 & 0.001 & 0.000 \\
\hline
\end{tabular}


TABLE E4 continued. Summary of all 63 models tested for Song Sparrow, including model terms, number of parameters $(K)$, log likelihood value, QAIC and QAIC scores, change in QAIC score ( $\mathrm{QAIC}_{c}$ ) between models, likelihood value $(\mathrm{L})$ and $\mathrm{AIC}_{c}$ weight $\left(\mathrm{W}_{\mathrm{i}}\right)$. SHRUB \% COVER

$$
\% \text { COVER COVER SPECIES POISON }
$$

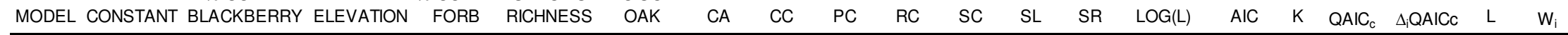

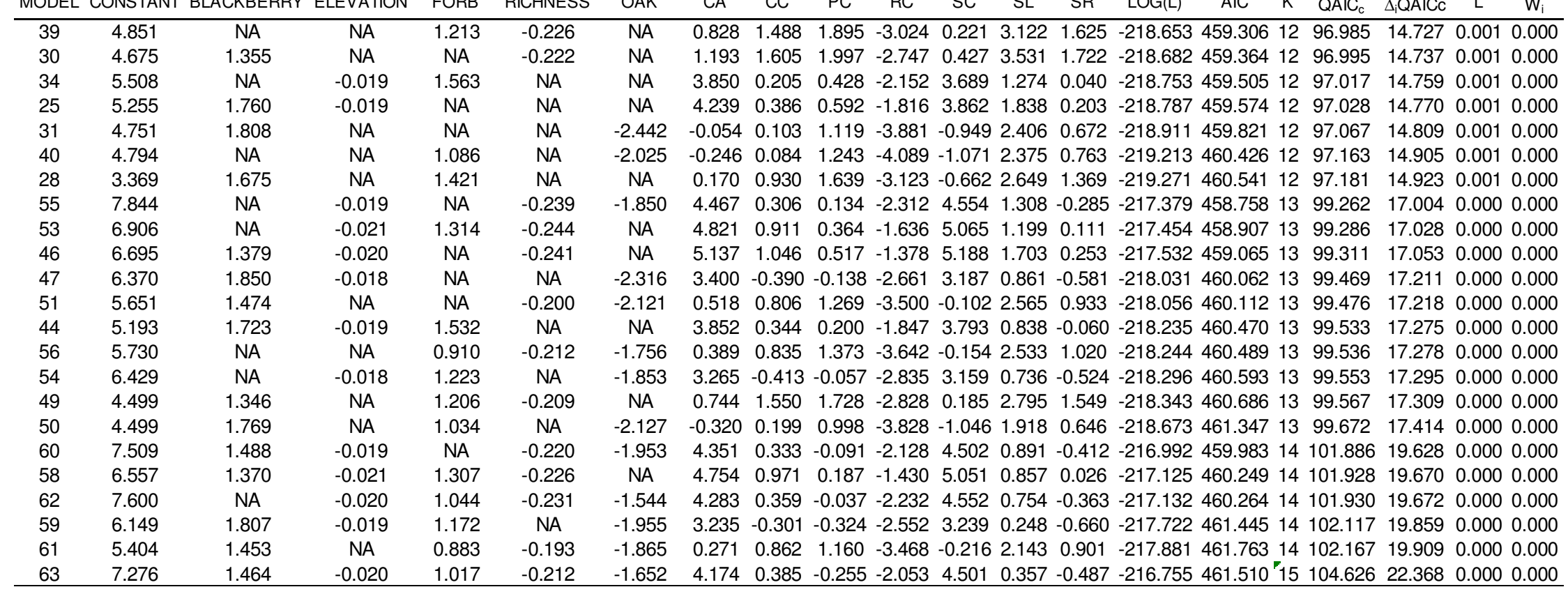


TABLE E5. Summary of all 63 models tested for Spotted Towhee, including model terms, number of parameters (K), log likelihood value, $A I C$ and $A I C c$ scores, change in AICc score ( $A I C c)$ between models, likelihood value (L) and AICc weight (Wi).

\begin{tabular}{|c|c|c|c|c|c|c|c|c|c|c|c|c|c|c|c|c|c|c|c|c|}
\hline MODEL & CONSTANT & ELEVATION & $\begin{array}{c}\text { SHRUB } \\
\text { SPECIES } \\
\text { RICHNESS }\end{array}$ & $\begin{array}{c}\% \text { COVER } \\
\text { DOGWOOD }\end{array}$ & $\begin{array}{c}\% \text { COVER } \\
\text { POISON } \\
\text { OAK }\end{array}$ & $\begin{array}{c}\% \text { COVER } \\
\text { CANOPY }\end{array}$ & CA & $\mathrm{CC}$ & PC & $\mathrm{RC}$ & SC & SL & SR & LOG(L) & AIC & $\mathrm{K}$ & $\mathrm{AlC}_{\mathrm{c}}$ & $\Delta_{\mathrm{i}} \mathrm{AICc}$ & L & $W_{i}$ \\
\hline 34 & 1.231 & $\mathrm{NA}$ & 0.063 & -1.673 & NA & NA & 0.213 & -0.251 & -0.478 & -0.832 & 0.061 & -0.889 & -0.943 & -60.064 & 142.128 & 11 & 145.271 & 0.000 & 1.000 & 0.207 \\
\hline 15 & 1.006 & NA & 0.062 & NA & NA & NA & 0.133 & -0.302 & -0.260 & -0.623 & 0.115 & -0.662 & -0.730 & -61.944 & 143.887 & 10 & 146.475 & 1.204 & 0.548 & 0.114 \\
\hline 18 & 1.542 & NA & NA & -1.657 & $\mathrm{NA}$ & NA & 0.358 & -0.057 & -0.476 & -0.729 & 0.308 & -0.908 & -0.900 & -62.361 & 144.721 & 10 & 147.310 & 2.039 & 0.361 & 0.075 \\
\hline 44 & 1.392 & -0.002 & 0.061 & -1.727 & NA & NA & 0.515 & -0.291 & -0.597 & -0.736 & 0.421 & -1.035 & -1.061 & -59.887 & 143.775 & 12 & 147.534 & 2.263 & 0.323 & 0.067 \\
\hline 53 & 1.174 & NA & 0.061 & -1.672 & 0.119 & NA & 0.250 & -0.206 & -0.438 & -0.789 & 0.091 & -0.837 & -0.899 & -60.011 & 144.021 & 12 & 147.781 & 2.510 & 0.285 & 0.059 \\
\hline 54 & 1.200 & NA & 0.063 & -1.687 & NA & 0.064 & 0.201 & -0.261 & -0.486 & -0.839 & 0.042 & -0.897 & -0.946 & -60.035 & 144.071 & 12 & 147.830 & 2.559 & 0.278 & 0.058 \\
\hline 6 & 1.317 & NA & NA & NA & NA & NA & 0.278 & -0.110 & -0.260 & -0.522 & 0.359 & -0.683 & -0.691 & -64.122 & 146.245 & 9 & 148.338 & 3.067 & 0.216 & 0.045 \\
\hline 25 & 1.105 & -0.001 & 0.061 & NA & NA & NA & 0.325 & -0.329 & -0.332 & -0.557 & 0.347 & -0.751 & -0.802 & -61.873 & 145.745 & 11 & 148.888 & 3.617 & 0.164 & 0.034 \\
\hline 36 & 0.949 & NA & 0.061 & NA & 0.120 & NA & 0.171 & -0.256 & -0.220 & -0.580 & 0.144 & -0.609 & -0.686 & -61.891 & 145.782 & 11 & 148.925 & 3.654 & 0.161 & 0.033 \\
\hline 37 & 0.992 & NA & 0.062 & NA & NA & 0.028 & 0.127 & -0.307 & -0.263 & -0.625 & 0.106 & -0.665 & -0.731 & -61.938 & 145.876 & 11 & 149.019 & 3.748 & 0.153 & 0.032 \\
\hline 28 & 1.740 & -0.002 & NA & -1.727 & NA & NA & 0.743 & -0.116 & -0.629 & -0.607 & 0.764 & -1.095 & -1.054 & -62.079 & 146.158 & 11 & 149.301 & 4.030 & 0.133 & 0.028 \\
\hline 39 & 1.431 & NA & NA & -1.657 & 0.212 & NA & 0.420 & 0.017 & -0.404 & -0.655 & 0.352 & -0.814 & -0.823 & -62.196 & 146.392 & 11 & 149.535 & 4.264 & 0.119 & 0.025 \\
\hline 40 & 1.530 & NA & NA & -1.663 & NA & 0.027 & 0.354 & -0.061 & -0.479 & -0.731 & 0.300 & -0.912 & -0.902 & -62.356 & 146.712 & 11 & 149.855 & 4.584 & 0.101 & 0.021 \\
\hline 58 & 1.335 & -0.002 & 0.060 & -1.728 & 0.133 & NA & 0.568 & -0.243 & -0. & -0.684 & 0.467 & -0 & -1. & -59.821 & 145.642 & 13 & 150.081 & 4.810 & 0.090 & 0.019 \\
\hline 59 & 1.361 & -0.002 & 0.062 & -1.742 & NA & 0.068 & 0.505 & -0.303 & -0.606 & -0.741 & 0.404 & -1.045 & -1.066 & -59.855 & 145.710 & 13 & 150.149 & 4.878 & 0.087 & 0.018 \\
\hline 62 & 1.155 & NA & 0.062 & -1.683 & 0.108 & 0.052 & 0.237 & -0.218 & -0.448 & -0.799 & 0.072 & -0.848 & -0.906 & -59.993 & 145.985 & 13 & 150.424 & 5.153 & 0.076 & 0.016 \\
\hline 20 & 1.205 & NA & NA & NA & 0.213 & NA & 0.340 & -0.035 & -0.189 & -0.448 & 0.403 & -0.588 & -0.613 & -63.962 & 147.924 & 10 & 150.513 & 5.242 & 0.073 & 0.015 \\
\hline 11 & 1.453 & -0.001 & NA & NA & NA & NA & 0.554 & -0.154 & & -0.428 & 30.690 & -0.811 & -0.795 & -63.979 & 147.958 & 10 & 150.546 & 5.275 & 0.072 & 0.015 \\
\hline 21 & 1.321 & NA & NA & NA & NA & -0.008 & 0.279 & -0.109 & -0.260 & -0.522 & 0.361 & -0.682 & -0.690 & -64.122 & 148.244 & 10 & 150.832 & 5.561 & 0.062 & 0.013 \\
\hline 46 & 1.049 & -0.001 & 0.060 & NA & 0.129 & NA & 0.377 & -0.282 & -0.293 & -0.506 & 0.392 & -0.699 & -0.758 & -61.812 & 147.624 & 12 & 151.383 & 6.112 & 0.047 & 0.010 \\
\hline 47 & 1.090 & -0.001 & 0.061 & $\mathrm{NA}$ & NA & 0.030 & 0.320 & -0.334 & -0.336 & -0.559 & 0.339 & -0.754 & -0.803 & -61.867 & 147.733 & 12 & 151.492 & 6.221 & 0.045 & 0.009 \\
\hline 55 & 0.943 & NA & 0.061 & NA & 0.117 & 0.015 & 0.167 & -0.260 & -0.222 & -0.5 & 0.139 & -0.612 & -0 & -61.890 & 147.779 & 12 & 151.538 & 6.267 & 0.044 & 0.009 \\
\hline 49 & 1.630 & -0.002 & NA & -1.729 & 0.227 & NA & 0.826 & -0.039 & -0.559 & -0.523 & 0.831 & -1.002 & -0 & -61.890 & 147.780 & 12 & 151.539 & 6.268 & 0.044 & 0.009 \\
\hline 50 & 1.727 & -0.002 & NA & -1.735 & NA & 0.033 & 0.740 & -0.120 & -0.634 & -0.609 & 0.757 & -1.100 & -1.056 & -62.072 & 148.144 & 12 & 151.903 & 6.632 & 0.036 & 0.008 \\
\hline 23 & 0.341 & 0.002 & 0.061 & NA & 0.526 & NA & NA & NA & NA & NA & NA & NA & NA & -70.683 & 151.367 & 5 & 152.033 & 6.762 & 0.034 & 0.007 \\
\hline 56 & 1.430 & NA & NA & -1.658 & 0.211 & 0.004 & 0.419 & 0.016 & -0.405 & -0.656 & 0.351 & -0.815 & -0.824 & -62.196 & 148.392 & 12 & 152.151 & 6.880 & 0.032 & 0.007 \\
\hline 7 & 0.422 & 0.002 & 0.062 & NA & NA & NA & NA & NA & NA & NA & NA & NA & NA & -71.915 & 151.831 & 4 & 152.270 & 6.999 & 0.030 & 0.006 \\
\hline 30 & 1.344 & -0.002 & NA & $\mathrm{NA}$ & 0.224 & NA & 0.635 & -0.078 & -0.295 & -0.345 & 0.756 & -0.719 & -0.720 & -63.802 & 149.604 & 11 & 152.747 & 7.476 & 0.024 & 0.005 \\
\hline 63 & 1.315 & -0.002 & 0.060 & -1.740 & 0.121 & 0.054 & 0.556 & -0.256 & -0.568 & -0.693 & 0.450 & -0.994 & -1.024 & -59.801 & 147.602 & 14 & 152.787 & 7.516 & 0.023 & 0.005 \\
\hline 41 & 1.217 & NA & NA & NA & 0.219 & -0.032 & 0.348 & -0.029 & -0.184 & -0.444 & 0.413 & -0.583 & -0.610 & -63.956 & 149.912 & 11 & 153.054 & 7.783 & 0.020 & 0.004 \\
\hline 31 & 1.456 & -0.001 & NA & NA & NA & -0.005 & 0.554 & -0.153 & -0.364 & -0.428 & 0.691 & -0.811 & -0.795 & -63.979 & 149.958 & 11 & 153.101 & 7.830 & 0.020 & 0.004 \\
\hline 60 & 1.043 & -0.001 & 0.060 & NA & 0.126 & 0.016 & 0.373 & -0.286 & -0.296 & -0.508 & 0.387 & -0.702 & -0.760 & -61.810 & 149.621 & 13 & 154.060 & 8.789 & 0.012 & 0.003 \\
\hline 22 & 0.427 & 0.002 & 0.059 & 0.432 & NA & NA & NA & NA & NA & NA & NA & NA & NA & -71.707 & 153.413 & 5 & 154.080 & 8.809 & 0.012 & 0.003 \\
\hline 42 & 0.348 & 0.002 & 0.059 & 0.307 & 0.506 & NA & NA & NA & NA & NA & NA & NA & NA & -70.577 & 153.155 & 6 & 154.098 & 8.827 & 0.012 & 0.003 \\
\hline 45 & 0.280 & 0.002 & 0.061 & NA & 0.518 & 0.124 & NA & NA & NA & NA & NA & NA & NA & -70.591 & 153.182 & 6 & 154.126 & 8.855 & 0.012 & 0.002 \\
\hline 61 & 1.627 & -0.002 & NA & -1.731 & 0.225 & 0.008 & 0.824 & -0.041 & -0.561 & -0.524 & 0.829 & -1.004 & -0.979 & -61.890 & 149.779 & 13 & 154.218 & 8.947 & 0.011 & 0.002 \\
\hline 24 & 0.347 & 0.002 & 0.062 & NA & NA & 0.147 & NA & NA & NA & NA & NA & NA & NA & -71.787 & 153.575 & 5 & 154.241 & 8.970 & 0.011 & 0.002 \\
\hline 9 & 0.667 & 0.002 & NA & NA & 0.544 & NA & NA & NA & NA & NA & NA & $\mathrm{NA}$ & NA & -73.042 & 154.084 & 4 & 154.523 & 9.252 & 0.010 & 0.002 \\
\hline 1 & 0.756 & 0.003 & NA & NA & NA & NA & NA & NA & NA & NA & NA & NA & NA & -74.298 & 154.596 & 3 & 154.857 & 9.586 & 0.008 & 0.002 \\
\hline 51 & 1.355 & -0.002 & NA & NA & 0.230 & -0.030 & 0.641 & -0.071 & -0.290 & -0.341 & 0.764 & -0.713 & -0.717 & -63.796 & 151.593 & 12 & 155.352 & 10.081 & 0.006 & 0.001 \\
\hline
\end{tabular}


TABLE E5 continued. Summary of all 63 models tested for Spotted Towhee, including model terms, number of parameters (K), log likelihood value, $\mathrm{AIC}$ and $\mathrm{AIC}_{c}$ scores, change in $\mathrm{AIC}_{c}$ score $\left(\mathrm{AIC}_{c}\right)$ between models, likelihood value $(\mathrm{L})$ and $\mathrm{AIC}$, weight $\left(\mathrm{W}_{\mathrm{i}}\right)$.

\begin{tabular}{|c|c|c|c|c|c|c|c|c|c|c|c|c|c|c|c|c|c|c|c|c|}
\hline MODEL & CONSTANT & ELEVATION & $\begin{array}{c}\text { SHRUB } \\
\text { SPECIES } \\
\text { RICHNESS }\end{array}$ & $\begin{array}{l}\% \text { COVER } \\
\text { DOGWOOD }\end{array}$ & $\begin{array}{c}\% \text { COVER } \\
\text { POISON } \\
\text { OAK }\end{array}$ & $\begin{array}{l}\% \text { COVER } \\
\text { CANOPY }\end{array}$ & $\mathrm{CA}$ & $\mathrm{CC}$ & PC & $\mathrm{RC}$ & SC & SL & SR & $\mathrm{LOG}(\mathrm{L})$ & AIC & $\mathrm{K}$ & $\mathrm{AlC}_{\mathrm{c}}$ & $\Delta_{\mathrm{i}} \mathrm{AICC}$ & L & $W_{i}$ \\
\hline 8 & 0.738 & 0.002 & NA & 0.670 & NA & NA & NA & $\mathrm{NA}$ & NA & NA & NA & NA & NA & -73.805 & 155.609 & 4 & 156.049 & 10.778 & 0.005 & 0.001 \\
\hline 26 & 0.658 & 0.002 & NA & 0.543 & 0.508 & NA & NA & NA & NA & NA & NA & NA & NA & -72.715 & 155.429 & 5 & 156.096 & 10.825 & 0.004 & 0.001 \\
\hline 43 & 0.359 & 0.002 & 0.059 & 0.409 & NA & 0.134 & NA & NA & NA & NA & NA & NA & NA & -71.601 & 155.202 & 6 & 156.146 & 10.875 & 0.004 & 0.001 \\
\hline 57 & 0.290 & 0.002 & 0.059 & 0.288 & 0.500 & 0.115 & NA & NA & NA & NA & NA & NA & NA & -70.498 & 154.995 & 7 & 156.268 & 10.997 & 0.004 & 0.001 \\
\hline 29 & 0.597 & 0.002 & NA & NA & 0.535 & 0.137 & NA & $N A$ & NA & NA & NA & NA & NA & -72.934 & 155.868 & 5 & 156.535 & 11.264 & 0.004 & 0.001 \\
\hline 10 & 0.673 & 0.003 & NA & NA & NA & 0.161 & NA & NA & NA & NA & NA & NA & NA & -74.152 & 156.304 & 4 & 156.743 & 11.472 & 0.003 & 0.001 \\
\hline 27 & 0.667 & 0.002 & NA & 0.645 & NA & 0.139 & NA & NA & NA & NA & NA & NA & NA & -73.696 & 157.392 & 5 & 158.058 & 12.787 & 0.002 & 0.000 \\
\hline 48 & 0.597 & 0.002 & NA & 0.523 & 0.502 & 0.120 & NA & $N A$ & NA & NA & NA & NA & NA & -72.632 & 157.263 & 6 & 158.207 & 12.936 & 0.002 & 0.000 \\
\hline 13 & 0.156 & NA & 0.113 & NA & 0.843 & NA & NA & NA & NA & NA & NA & NA & NA & -77.071 & 162.142 & 4 & 162.582 & 17.311 & 0.000 & 0.000 \\
\hline 32 & 0.201 & NA & 0.099 & 0.985 & 0.741 & NA & NA & NA & NA & NA & NA & NA & NA & -76.008 & 162.015 & 5 & 162.682 & 17.411 & 0.000 & 0.000 \\
\hline 35 & -0.022 & NA & 0.106 & NA & 0.785 & 0.398 & NA & NA & NA & NA & NA & NA & NA & -76.160 & 162.320 & 5 & 162.987 & 17.716 & 0.000 & 0.000 \\
\hline 52 & 0.043 & NA & 0.095 & 0.869 & 0.703 & 0.342 & NA & NA & NA & NA & NA & NA & NA & -75.336 & 162.673 & 6 & 163.617 & 18.346 & 0.000 & 0.000 \\
\hline 12 & 0.302 & NA & 0.105 & 1.273 & NA & NA & NA & NA & NA & NA & NA & NA & NA & -78.242 & 164.483 & 4 & 164.923 & 19.652 & 0.000 & 0.000 \\
\hline 33 & 0.111 & NA & 0.100 & 1.121 & NA & 0.398 & NA & $N A$ & NA & NA & NA & NA & NA & -77.361 & 164.721 & 5 & 165.388 & 20.117 & 0.000 & 0.000 \\
\hline 14 & 0.035 & NA & 0.116 & NA & NA & 0.482 & NA & NA & NA & NA & NA & NA & NA & -78.712 & 165.424 & 4 & 165.863 & 20.592 & 0.000 & 0.000 \\
\hline 2 & 0.260 & NA & 0.124 & NA & NA & NA & NA & NA & NA & NA & NA & NA & NA & -79.995 & 165.990 & 3 & 166.251 & 20.980 & 0.000 & 0.000 \\
\hline 38 & 0.509 & NA & NA & 1.622 & 0.811 & 0.467 & NA & NA & NA & NA & NA & NA & NA & -81.139 & 172.279 & 5 & 172.945 & 27.674 & 0.000 & 0.000 \\
\hline 16 & 0.756 & NA & NA & 1.824 & 0.870 & NA & NA & NA & NA & NA & NA & NA & NA & -82.264 & 172.527 & 4 & 172.967 & 27.696 & 0.000 & 0.000 \\
\hline 17 & 0.616 & NA & NA & 1.959 & NA & 0.541 & NA & NA & NA & NA & NA & NA & NA & -83.533 & 175.066 & 4 & 175.505 & 30.234 & 0.000 & 0.000 \\
\hline 3 & 0.914 & NA & NA & 2.224 & NA & NA & NA & NA & NA & NA & NA & NA & NA & -84.976 & 175.953 & 3 & 176.214 & 30.943 & 0.000 & 0.000 \\
\hline 19 & 0.487 & NA & NA & NA & 1.007 & 0.614 & NA & NA & NA & NA & NA & NA & NA & -83.908 & 175.817 & 4 & 176.256 & 30.985 & 0.000 & 0.000 \\
\hline 4 & 0.821 & NA & NA & NA & 1.121 & NA & NA & $\mathrm{NA}$ & NA & NA & NA & NA & NA & -85.797 & 177.595 & 3 & 177.856 & 32.585 & 0.000 & 0.000 \\
\hline 5 & 0.621 & NA & NA & NA & NA & 0.749 & NA & $\mathrm{NA}$ & NA & NA & NA & NA & NA & -87.527 & 181.055 & 3 & 181.316 & 36.045 & 0.000 & 0.000 \\
\hline
\end{tabular}


TABLE E6. Summary of all 63 models tested for Swainson's Thrush, including model terms, number of parameters (K), log likelihood value, AIC and AICc scores, change in AICc score ( AICc) between models, likelihood value (L) and AICc weight (Wi).

TREE

$\%$ COVER \% COVER \% COVER SPECIES

\begin{tabular}{|c|c|c|c|c|c|c|c|c|c|c|c|c|c|c|c|c|c|c|c|c|}
\hline DDE & & & BB & WILLOW & RASS & RICHNESS & $\mathrm{CA}$ & $\mathrm{CC}$ & $P C$ & $\mathrm{RC}$ & SC & SL & SR & LOG(L) & AlC & $\mathrm{K}$ & $\mathrm{AlC}_{\mathrm{c}}$ & $\Delta_{\mathrm{i}} \mathrm{AlCc}$ & $\mathrm{L}$ & $W_{i}$ \\
\hline 25 & 3.453 & -0.012 & 1.527 & $\mathrm{NA}$ & NA & $\mathrm{NA}$ & 0.911 & 0.425 & -3.287 & -1.88 & -0.22 & -1.863 & -0.313 & -160.611 & 343.222 & 11 & 346.365 & 0.000 & 1.000 & 0.150 \\
\hline 15 & 2.298 & NA & 1.535 & NA & NA & NA & -1.407 & 0.791 & -2.406 & -2.671 & -3.006 & -0.781 & 0.569 & -161.948 & 343.897 & 10 & 346.485 & .120 & 942 & 0.141 \\
\hline 46 & 3.564 & -0.013 & 1.459 & NA & -1.906 & NA & 1.141 & 0.469 & -3.18 & -1.604 & -0.049 & -1.935 & -0.34 & -160.064 & 344.128 & 12 & 347.887 & .522 & .467 & 0.070 \\
\hline 11 & 4.659 & -0.012 & NA & NA & NA & NA & 0.395 & 0.584 & -3.885 & -2.324 & -0.546 & -2.366 & -0.627 & -162.814 & 345.627 & 10 & 348.216 & .851 & .396 & 0.059 \\
\hline 36 & 2.344 & NA & 1.476 & NA & -1.661 & NA & -1.306 & 0.845 & -2.275 & -2.466 & -2.977 & -0.797 & 0.583 & -161.542 & 345.085 & 11 & 348.228 & .863 & .394 & 0.059 \\
\hline 6 & 3.5 & NA & NA & NA & NA & NA & -1.944 & 0.955 & -3 & -3.125 & -3.357 & -1.278 & 0.26 & -164.113 & 346.225 & 9 & 348.318 & .953 & .377 & 0.056 \\
\hline 44 & 3.68 & -0.014 & 1.671 & -0.575 & NA & NA & 1.154 & 0.452 & -3.301 & -1.849 & 0.025 & -1.976 & -0.39 & -160.425 & 344.849 & 12 & 348.609 & 244 & .326 & 0.049 \\
\hline 47 & 3.447 & -0.012 & 1.526 & NA & NA & 0.002 & 0.907 & 0.429 & -3.286 & -1.879 & -0.224 & -1.864 & -0.313 & -160.611 & 345.222 & 12 & 348.981 & 2.616 & .270 & 0.040 \\
\hline 37 & 2.252 & NA & 1.52 & NA & NA & 0.014 & -1.424 & 0.826 & -2.404 & -2.665 & -3.031 & -0.787 & 0.566 & -161.942 & 345.883 & 11 & 349.026 & 2.661 & .264 & 0.040 \\
\hline 34 & 2.309 & NA & 1.553 & -0.07 & NA & NA & -1.411 & 0.8 & -2.395 & -2.679 & -3.017 & -0.78 & 0.572 & -161.945 & 345.891 & 11 & 349.034 & 2.669 & .263 & 0.039 \\
\hline 30 & 4.725 & -0.013 & NA & NA & -2.242 & NA & 0.693 & 0.627 & -3.728 & -1.977 & -0.328 & -2.424 & -0.642 & -162.083 & 346.167 & 11 & 349.309 & 2.944 & .229 & 0.034 \\
\hline 20 & 3.5 & NA & NA & NA & -1.997 & NA & -1.798 & 1.012 & -2.815 & -2.857 & -3.306 & -1.273 & 0.292 & -163.546 & 347.093 & 10 & 349.681 & 3.316 & .191 & 0.029 \\
\hline 58 & 3.884 & -0.015 & 1.643 & -0.771 & -2.169 & NA & 1.5 & 0.512 & -3.184 & -1.525 & 0.304 & -2.095 & -0.446 & -159.735 & 345.469 & 13 & 349.908 & 43 & .170 & 0.025 \\
\hline 18 & 329 & NA & NA & 0.484 & NA & NA & -1.875 & 0.882 & -3.029 & -3.036 & -3.257 & -1.252 & 0.261 & -163.964 & 347.928 & 10 & 350.516 & .151 & 25 & 0.019 \\
\hline 60 & 3.635 & -0.013 & 1.478 & NA & -1.953 & -0.019 & 1.184 & 0.422 & -3.186 & -1.602 & 0.006 & -1.936 & -0.342 & -160.051 & 346.103 & 13 & 350.542 & 4.177 & .124 & 0.019 \\
\hline 21 & 262 & NA & NA & NA & NA & 0 & -1.992 & 1.089 & -2.966 & -3.08 & -3.446 & -1.281 & 0.263 & -163.999 & 347.997 & 10 & 350.585 & 4.220 & 0.121 & 0.018 \\
\hline 31 & 4.454 & -0.012 & NA & NA & NA & 0. & 0.322 & 0.695 & -3.845 & -2.301 & -0.658 & -2.352 & -0.612 & -162.741 & 347.482 & 11 & 350.625 & 4.260 & .119 & 0.018 \\
\hline 28 & 4.615 & .012 & NA & 0.074 & NA & NA & 0.37 & 0.579 & -3.876 & -2.323 & -0.574 & -2.346 & -0.613 & -162.81 & 347.621 & 11 & 350.764 & 4.399 & 0.111 & 0.017 \\
\hline 53 & 2.376 & NA & 1.522 & -0 & -1.716 & $\mathrm{~N}$ & -1.313 & 0.871 & -2.241 & -2.48 & -3.005 & -0.792 & 0.593 & -161.521 & 347.041 & 12 & 350.801 & 4.436 & 0.109 & 0.016 \\
\hline 55 & 2.353 & IA & 1.478 & NA & -1.667 & -0.003 & -1.303 & 0.839 & -2.275 & -2.466 & -2.972 & -0.796 & 0.584 & -161.542 & 347.084 & 12 & 350.843 & 4.478 & 0.107 & 0.016 \\
\hline 59 & 3.708 & 0.014 & 1.681 & -0.5 & NA & 07 & 1.171 & 0.435 & -3.304 & -1.85 & 0.047 & -1.977 & -0.391 & -160.423 & 346.846 & 13 & 285 & 4.920 & 0.085 & 0.013 \\
\hline 54 & 2.264 & NA & 1.536 & -0.06 & NA & 0 & -1.427 & 0.832 & -2.394 & -2.672 & -3.039 & -0.785 & 0.569 & -16 & 879 & 12 & 38 & 5.273 & 0.072 & 0.011 \\
\hline 51 & 4.629 & 0.013 & NA & NA & -2.1 & 0.021 & 0.652 & 0.678 & -3.714 & -1.975 & -0.385 & -2.416 & -0.635 & 68 & 36 & 12 & 895 & 30 & 0.063 & 0.009 \\
\hline 49 & 4.814 & .013 & NA & -0.147 & -2.3 & NA & 0.751 & 0.639 & -3.742 & -1.971 & -0.267 & -2.466 & -0.67 & .071 & 348.142 & 12 & 351.901 & 5.536 & 0.063 & 0.009 \\
\hline 39 & 38 & $N A$ & NA & 0.34 & -1.879 & NA & -1.758 & 0.957 & -2.846 & -2.81 & -3.239 & -1.256 & 0.291 & 474 & 348.948 & 11 & 352.091 & 5.726 & 0. & 0.009 \\
\hline 41 & 3.347 & NA & NA & NA & -1.899 & 0.0 & -1.836 & 1.096 & -2.802 & -2.841 & -3.365 & -1.276 & 0.292 & -163.5 & 349 & 11 & 352.142 & 5.777 & 0.056 & 0.008 \\
\hline 63 & 4.03 & -0.015 & 1.686 & -0.812 & -2.267 & 34 & 1.596 & 0.429 & -3.195 & -1.516 & 0.422 & -2.105 & -0.457 & -159.694 & 347.389 & 14 & 352.574 & 6.209 & 0.045 & 0.007 \\
\hline 40 & 3.076 & NA & NA & 0.499 & NA & 0.059 & -1.922 & 1.019 & -2.995 & -2.986 & -3.346 & -1.255 & 0.264 & -163.84 & 349.681 & 11 & 352.824 & 6.459 & 0.040 & 0.006 \\
\hline 50 & 4.396 & -0.012 & NA & 0.093 & NA & 0.046 & 0.29 & 0.69 & -3.833 & -2.299 & -0.695 & -2.326 & -0.594 & -162.736 & 349.472 & 12 & 353.231 & 6.866 & 0.032 & 0.005 \\
\hline 62 & 2.396 & NA & 1.529 & -0.196 & -1.732 & -0.006 & -1.306 & 0.858 & -2.239 & -2.481 & -2.995 & -0.79 & 0.594 & -161.52 & 349.039 & 13 & 353.478 & 7.113 & 0.029 & 0.004 \\
\hline 61 & 4.716 & -0.013 & NA & -0 & -2.242 & 0.019 & 0.707 & 0.685 & -3.727 & -1.97 & -0.326 & -2.454 & -0.66 & -162.058 & 350.116 & 13 & 354.555 & 8.190 & 0.017 & 0.002 \\
\hline 56 & 3.207 & NA & NA & 0.358 & -1.768 & 0.04 & -1.797 & 1.045 & -2.834 & -2.79 & -3.3 & -1.257 & 0.291 & -163.42 & 350.84 & 12 & 354.599 & 8.234 & 0.016 & 0.002 \\
\hline 23 & 1.24 & 0.007 & 3.417 & NA & -4.621 & NA & NA & NA & NA & NA & NA & NA & NA & .998 & 375.997 & 5 & 376.664 & 30.299 & 0.000 & 0.000 \\
\hline 45 & 1.67 & -0.007 & 3.322 & NA & -5.065 & -0.104 & NA & NA & NA & NA & NA & NA & NA & -182.631 & 377.262 & 6 & 378.206 & 31.841 & 0.000 & 0.000 \\
\hline 42 & 1.427 & -0.008 & 3.6 & -0.72 & -4.732 & NA & NA & NA & NA & NA & NA & NA & NA & -182.777 & 377.554 & 6 & 378.498 & 32.133 & 0.000 & 0.000 \\
\hline 7 & 0.87 & -0.007 & 3.757 & NA & NA & NA & NA & NA & NA & NA & NA & NA & NA & -185.483 & 378.965 & 4 & 379.405 & 33.040 & 0.000 & 0.000 \\
\hline 57 & 1.98 & -0.007 & 3.537 & -0.91 & -5.283 & -0.122 & NA & NA & NA & NA & NA & NA & NA & -182.285 & 378.571 & 7 & 379.843 & 33.478 & 0.000 & 0.000 \\
\hline 22 & 0.997 & -0.008 & 3.894 & -0.515 & NA & NA & NA & NA & NA & NA & NA & NA & NA & -185.374 & 380.749 & 5 & 381.415 & 35.050 & 0.000 & 0.000 \\
\hline 24 & 0.992 & -0.007 & 3.738 & NA & NA & -0.032 & NA & NA & NA & NA & NA & NA & NA & -185.447 & 380.894 & 5 & 381.561 & 35.196 & 0.000 & 0.000 \\
\hline 43 & 1.168 & -0.008 & 3.884 & -0.572 & NA & -0.041 & NA & NA & NA & NA & NA & $\mathrm{NA}$ & NA & -185.317 & 382.633 & 6 & 383.577 & 37.212 & 0.000 & 0.000 \\
\hline
\end{tabular}


TABLE E6 continued. Summary of all 63 models tested for Swainson's Thrush, including model terms, number of parameters $(K)$, log likelihood value, $\mathrm{AIC}$ and $\mathrm{AIC}_{c}$ scores, change in $\mathrm{AIC}_{c}$ score $\left(\mathrm{AIC}_{c}\right)$ between models, likelihood value $(\mathrm{L})$ and $\mathrm{AIC}_{c}$ weight $\left(\mathrm{W}_{\mathrm{i}}\right)$.

$\%$ COVER \% COVER \% COVER SPECIES

\begin{tabular}{|c|c|c|c|c|c|c|c|c|c|c|c|c|c|c|c|c|c|c|c|c|}
\hline MODEL & DNSTAN & EVATION & SHRUB & WILLOW & GRASS & RICHNESS & CA & $\mathrm{CC}$ & PC & $\mathrm{RC}$ & SC & SL & SR & LOG(L) & AIC & $\mathrm{K}$ & $\mathrm{AlC}_{\mathrm{c}}$ & $\Delta_{\mathrm{i}} \mathrm{AlCc}$ & L & $W_{i}$ \\
\hline 35 & 1.943 & NA & 3.267 & $\mathrm{NA}$ & -6.5 & -0.328 & NA & NA & NA & NA & NA & NA & NA & -191.062 & 392.123 & 5 & 392.79 & 46.425 & 0.000 & 0.000 \\
\hline 52 & 1.569 & NA & 3.032 & 1.018 & -6.115 & -0.286 & NA & NA & NA & NA & NA & NA & NA & -190.623 & 393.247 & 6 & 394.19 & 47.825 & 0.000 & 0.000 \\
\hline 9 & 3.299 & -0.007 & NA & NA & -6.649 & NA & NA & NA & NA & NA & NA & NA & NA & -193.108 & 394.215 & 4 & 394.655 & 48.290 & 0.000 & 0.000 \\
\hline 29 & 3.974 & -0.006 & NA & NA & -7.353 & -0.188 & NA & NA & NA & NA & NA & NA & NA & -192.1 & 394.2 & 5 & 394.866 & 48.501 & 0.000 & 0.000 \\
\hline 26 & 2.849 & -0.007 & NA & 1.088 & -6.316 & NA & NA & NA & NA & NA & NA & NA & NA & -192.637 & 395.274 & 5 & 395.94 & 49.575 & 0.000 & 0.000 \\
\hline 48 & 3.58 & -0.006 & NA & 0.782 & -7.039 & -0.168 & NA & NA & NA & NA & NA & NA & NA & -191.864 & 395.728 & 6 & 396.672 & 50.307 & 0.000 & 0.000 \\
\hline 32 & 0.049 & NA & 3.1 & 1.882 & -4.838 & NA & NA & NA & NA & NA & NA & NA & NA & -193.103 & 396.206 & 5 & 396.873 & 50.508 & 0.000 & 0.000 \\
\hline 13 & 0.367 & NA & 3.618 & NA & -5.255 & NA & NA & NA & NA & NA & NA & NA & NA & -194.709 & 397.418 & 4 & 397.857 & 51.492 & 0.000 & 0.000 \\
\hline 14 & 1.082 & NA & 3.808 & NA & NA & -0.26 & NA & NA & NA & NA & NA & NA & NA & -195.005 & 398.01 & 4 & 398.45 & 52.085 & 0.000 & 0.000 \\
\hline 33 & 0.595 & NA & 3.405 & 1.535 & NA & -0.202 & NA & NA & NA & NA & NA & NA & NA & -194.052 & 398.104 & 5 & 398.771 & 52.406 & 0.000 & 0.000 \\
\hline 12 & -0.398 & NA & 3.397 & 2.105 & NA & NA & NA & NA & NA & NA & NA & NA & NA & -195.302 & 398.604 & 4 & 399.043 & 52.678 & 0.000 & 0.000 \\
\hline 2 & -0.082 & NA & 4.012 & NA & NA & NA & NA & NA & NA & NA & NA & NA & NA & -197.234 & 400.468 & 3 & 400.729 & 54.364 & 0.000 & 0.000 \\
\hline 1 & 3.05 & -0.008 & NA & NA & NA & NA & NA & NA & NA & NA & NA & NA & NA & -197.384 & 400.768 & 3 & 401.029 & 54.664 & 0.000 & 0.000 \\
\hline 8 & 2.419 & -0.007 & NA & 1.572 & NA & NA & NA & NA & NA & NA & NA & NA & NA & -196.46 & 400.919 & 4 & 401.359 & 54.994 & 0.000 & 0.000 \\
\hline 10 & 3.375 & -0.007 & NA & NA & NA & -0.094 & NA & NA & NA & NA & NA & NA & NA & -197.144 & 402.287 & 4 & 402.727 & 56.362 & 0.000 & 0.000 \\
\hline 27 & 2.678 & -0.006 & NA & 1.476 & NA & -0.064 & NA & NA & NA & NA & NA & NA & NA & -196.35 & 402.701 & 5 & 403.367 & 57.002 & 0.000 & 0.000 \\
\hline 38 & 3.033 & NA & NA & 2.222 & -7.535 & -0.303 & NA & NA & NA & NA & NA & NA & NA & -196.9 & 403.8 & 5 & 404.467 & 58.102 & 0.000 & 0.000 \\
\hline 19 & 4.206 & NA & NA & NA & -8.725 & -0.407 & NA & NA & NA & NA & NA & NA & NA & -198.885 & 405.77 & 4 & 406.21 & 59.845 & 0.000 & 0.000 \\
\hline 16 & 1.456 & NA & NA & 3.167 & -6.215 & NA & NA & NA & NA & NA & NA & NA & NA & -199.345 & 406.69 & 4 & 407.129 & 60.764 & 0.000 & 0.000 \\
\hline 3 & 1.044 & NA & NA & 3.624 & NA & NA & NA & NA & NA & NA & NA & NA & NA & -202.584 & 411.168 & 3 & 411.429 & 65.064 & 0.000 & 0.000 \\
\hline 17 & 2.027 & NA & NA & 3.065 & NA & -0.2 & NA & NA & NA & NA & NA & NA & NA & -201.542 & 411.085 & 4 & 411.524 & 65.159 & 0.000 & 0.000 \\
\hline 4 & 2.507 & NA & NA & NA & -7.443 & NA & NA & NA & NA & NA & NA & NA & NA & -203.721 & 413.442 & 3 & 413.703 & 67.338 & 0.000 & 0.000 \\
\hline 5 & 3.514 & NA & NA & NA & NA & -0.328 & NA & NA & NA & NA & NA & NA & NA & -205.13 & 416.26 & 3 & 416.521 & 70.156 & 0.000 & 0.000 \\
\hline
\end{tabular}


TABLE E7. Summary of all 63 models tested for Warbling Vireo, including model terms, number of parameters (K), log likelihood value, $\mathrm{AIC}$ and AICc scores, change in AICc score ( $\mathrm{AICc}$ ) between models, likelihood value (L) and AICc weight (Wi).

TREE TREE

$\%$ COVER DBH SPECIES HEIGHT \% COVER

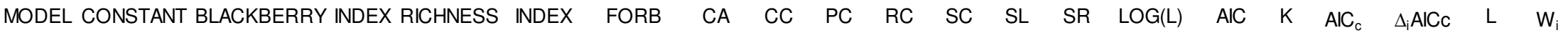

\begin{tabular}{|c|c|c|c|c|c|c|c|c|c|c|c|c|c|c|c|c|c|c|c|}
\hline 25 & 0.945 & 0.697 & 0.003 & NA & NA & NA & -0.136 & -0.601 & 0.295 & -0.613 & 0.224 & 0.140 & -0.731 & -77.669 & 177.337 & 11 & 180.480 & 0.000 & 1.0000 .103 \\
\hline 30 & 0.724 & 0.729 & NA & NA & 0.033 & NA & -0.142 & -0.578 & 0.398 & -0.544 & 0.266 & 0.166 & -0.656 & -77.744 & 177.488 & 11 & 180.630 & 0.150 & 0.9280 .096 \\
\hline 6 & 1.358 & NA & NA & NA & NA & NA & -0.086 & -0.780 & 0.393 & -0.804 & 0.182 & 0.268 & -0.717 & -80.461 & 178.923 & 9 & 181.016 & 0.536 & 0.7650 .079 \\
\hline 15 & 1.038 & NA & 0.004 & NA & NA & NA & -0.116 & -0.641 & 0.381 & -0.716 & 0.213 & 0.323 & -0.694 & -79.214 & 178.428 & 10 & 181.016 & 0.536 & 0.7650 .079 \\
\hline 28 & 1.005 & 0.772 & NA & 0.048 & NA & NA & -0.153 & -0.602 & 0.325 & -0.638 & 0.125 & 0.071 & -0.753 & -78.130 & 178.261 & 11 & 181.404 & 0.924 & 0.6300 .065 \\
\hline 20 & 0.819 & NA & NA & NA & 0.037 & NA & -0.119 & -0.625 & 0.499 & -0.651 & 0.257 & 0.357 & -0.610 & -79.445 & 178.891 & 10 & 181.479 & 0.999 & 0.6070 .063 \\
\hline 46 & 0.633 & 0.683 & 0.002 & NA & 0.025 & NA & -0.153 & -0.521 & 0.372 & -0.525 & 0.269 & 0.196 & -0.661 & -77.203 & 178.406 & 12 & 182.165 & 1.685 & 0.4310 .044 \\
\hline 31 & 1.214 & 0.769 & NA & NA & NA & -0.099 & -0.079 & -0.714 & 0.319 & -0.672 & 0.215 & 0.135 & -0.741 & -78.563 & 179.126 & 11 & 182.269 & 1.789 & 0.4090 .042 \\
\hline 44 & 0.799 & 0.708 & 0.003 & 0.040 & NA & NA & -0.168 & -0.517 & 0.318 & -0.585 & 0.161 & 0.132 & -0.732 & -77.342 & 178.683 & 12 & 182.442 & 1.962 & $0.375 \quad 0.039$ \\
\hline 36 & 0.704 & NA & 0.003 & NA & 0.027 & NA & -0.134 & -0.554 & 0.461 & -0.620 & 0.262 & 0.378 & -0.620 & -78.699 & 179.399 & 11 & 182.542 & 2.062 & 0.3570 .037 \\
\hline 18 & 1.165 & NA & NA & 0.046 & NA & NA & -0.125 & -0.671 & 0.421 & -0.767 & 0.111 & 0.265 & -0.715 & -80.031 & 180.061 & 10 & 182.650 & 2.170 & 0.3380 .035 \\
\hline 47 & 0.943 & 0.697 & 0.003 & NA & NA & -0.181 & -0.075 & -0.592 & 0.335 & -0.599 & 0.254 & 0.255 & -0.705 & -77.526 & 179.053 & 12 & 182.812 & 2.332 & 0.3120 .032 \\
\hline 49 & 0.685 & 0.738 & NA & 0.028 & 0.028 & NA & -0.160 & -0.535 & 0.398 & -0.543 & 0.212 & 0.149 & -0.671 & -77.604 & 179.208 & 12 & 182.967 & 2.487 & $0.288 \quad 0.030$ \\
\hline 34 & 0.904 & NA & 0.003 & 0.037 & NA & NA & -0.145 & -0.563 & 0.404 & -0.692 & 0.154 & 0.318 & -0.694 & -78.940 & 179.881 & 11 & 183.023 & 2.543 & 0.2800 .029 \\
\hline 51 & 0.735 & 0.731 & NA & NA & 0.033 & -0.071 & -0.117 & -0.578 & 0.412 & -0.542 & 0.276 & 0.209 & -0.647 & -77.721 & 179.443 & 12 & 183.202 & 2.722 & $\begin{array}{lll}0.256 & 0.026\end{array}$ \\
\hline 37 & 1.037 & NA & 0.004 & NA & NA & -0.181 & -0.055 & -0.631 & 0.421 & -0.702 & 0.243 & 0.438 & -0.668 & -79.076 & 180.153 & 11 & 183.296 & 2.816 & 0.2450 .025 \\
\hline 21 & 1.366 & NA & NA & NA & NA & -0.084 & -0.057 & -0.779 & 0.412 & -0.800 & 0.196 & 0.319 & -0.705 & -80.432 & 180.863 & 10 & 183.451 & 2.971 & 0.2260 .023 \\
\hline 39 & 0.787 & NA & NA & 0.023 & 0.032 & NA & -0.135 & -0.590 & 0.500 & -0.651 & 0.212 & 0.345 & -0.622 & -79.350 & 180.700 & 11 & 183.843 & 3.363 & 0.1860 .019 \\
\hline 50 & 1.012 & 0.775 & NA & 0.048 & NA & -0.110 & -0.116 & -0.600 & 0.349 & -0.632 & 0.142 & 0.138 & -0.738 & -78.077 & 180.155 & 12 & 183.914 & 3.434 & $0.180 \quad 0.019$ \\
\hline 41 & 0.828 & NA & NA & NA & 0.036 & -0.054 & -0.100 & -0.626 & 0.511 & -0.649 & 0.265 & 0.390 & -0.603 & -79.433 & 180.865 & 11 & 184.008 & 3.528 & 0.1710 .018 \\
\hline 58 & 0.598 & 0.693 & 0.002 & 0.026 & 0.020 & NA & -0.171 & -0.481 & 0.373 & -0.524 & 0.219 & 0.179 & -0.675 & -77.076 & 180.153 & 13 & 184.592 & 4.112 & 0.1280 .013 \\
\hline 60 & 0.648 & 0.684 & 0.003 & NA & 0.024 & -0.145 & -0.103 & -0.517 & 0.400 & -0.519 & 0.291 & 0.285 & -0.644 & -77.113 & 180.225 & 13 & 184.664 & 4.184 & 0.1230 .013 \\
\hline 59 & 0.796 & 0.708 & 0.003 & 0.040 & NA & -0.185 & -0.106 & -0.506 & 0.359 & -0.571 & 0.191 & 0.249 & -0.705 & -77.194 & 180.387 & 13 & 184.826 & 4.346 & 0.1140 .012 \\
\hline 53 & 0.675 & NA & 0.003 & 0.022 & 0.023 & NA & -0.149 & -0.521 & 0.463 & -0.621 & 0.220 & 0.367 & -0.631 & -78.614 & 181.229 & 12 & 184.988 & 4.508 & 0.1050 .011 \\
\hline 55 & 0.719 & NA & 0.003 & NA & 0.026 & -0.142 & -0.086 & -0.551 & 0.489 & -0.614 & 0.283 & 0.466 & -0.603 & -78.615 & 181.231 & 12 & 184.990 & 4.510 & 0.1050 .011 \\
\hline 40 & 1.172 & NA & NA & 0.047 & NA & -0.095 & -0.093 & -0.669 & 0.442 & -0.763 & 0.125 & 0.323 & -0.702 & -79.993 & 181.986 & 11 & 185.128 & 4.648 & $0.098 \quad 0.010$ \\
\hline 54 & 0.902 & NA & 0.004 & 0.037 & NA & -0.184 & -0.083 & -0.552 & 0.444 & -0.678 & 0.184 & 0.434 & -0.667 & -78.798 & 181.595 & 12 & 185.354 & 4.874 & 0.0870 .009 \\
\hline 61 & 0.697 & 0.741 & NA & 0.028 & 0.027 & -0.082 & -0.132 & -0.534 & 0.415 & -0.540 & 0.223 & 0.198 & -0.661 & -77.574 & 181.148 & 13 & 185.587 & 5.107 & 0.0780 .008 \\
\hline 56 & 0.797 & NA & NA & 0.024 & 0.032 & -0.064 & -0.113 & -0.589 & 0.513 & -0.649 & 0.220 & 0.383 & -0.614 & -79.333 & 182.666 & 12 & 186.425 & 5.945 & 0.0510 .005 \\
\hline 63 & 0.612 & 0.694 & 0.003 & 0.028 & 0.019 & -0.155 & -0.118 & -0.475 & 0.402 & -0.517 & 0.239 & 0.274 & -0.657 & -76.973 & 181.946 & 14 & 187.131 & 6.651 & 0.0360 .004 \\
\hline 62 & 0.689 & NA & 0.003 & 0.023 & 0.021 & -0.151 & -0.098 & -0.516 & 0.492 & -0.614 & 0.240 & 0.459 & -0.613 & -78.520 & 183.040 & 13 & 187.479 & 6.999 & 0.0300 .003 \\
\hline 22 & 0.150 & 1.231 & 0.004 & 0.092 & NA & NA & NA & NA & NA & NA & NA & NA & NA & -96.881 & 203.761 & 5 & 204.428 & 23.948 & 0.0000 .000 \\
\hline 8 & 0.351 & 1.359 & NA & 0.112 & NA & NA & NA & NA & NA & NA & NA & NA & NA & -98.030 & 204.060 & 4 & 204.500 & 24.020 & 0.0000 .000 \\
\hline 26 & 0.026 & 1.309 & NA & 0.083 & 0.037 & NA & NA & NA & NA & NA & NA & NA & NA & -97.231 & 204.463 & 5 & 205.129 & 24.649 & 0.0000 .000 \\
\hline 9 & 0.080 & 1.327 & NA & NA & 0.060 & NA & NA & NA & NA & NA & NA & NA & NA & -98.631 & 205.263 & 4 & 205.703 & 25.223 & 0.0000 .000 \\
\hline 27 & 0.327 & 1.213 & NA & 0.104 & $N A$ & 0.318 & NA & NA & NA & NA & NA & NA & NA & -97.523 & 205.046 & 5 & 205.713 & 25.233 & 0.0000 .000 \\
\hline 43 & 0.140 & 1.114 & 0.004 & 0.087 & NA & 0.273 & NA & NA & NA & NA & NA & NA & NA & -96.503 & 205.006 & 6 & 205.950 & 25.470 & 0.0000 .000 \\
\hline 42 & -0.043 & 1.219 & 0.003 & 0.075 & 0.026 & NA & NA & NA & NA & NA & NA & NA & NA & -96.515 & 205.031 & 6 & 205.975 & 25.495 & 0.0000 .000 \\
\hline 23 & -0.005 & 1.220 & 0.004 & NA & 0.045 & NA & NA & NA & NA & NA & NA & NA & NA & -97.675 & 205.350 & 5 & 206.017 & 25.537 & $0.000 \quad 0.000$ \\
\hline
\end{tabular}


TABLE E7 continued. Summary of all 63 models tested for Warbling Vireo, including model terms, number of parameters $(K)$, log likelihood value, $\mathrm{AIC}$ and $\mathrm{AIC}_{c}$ scores, change in $\mathrm{AIC}_{c}$ score $\left(\mathrm{AIC}_{c}\right)$ between models, likelihood value $(\mathrm{L})$ and $\mathrm{AIC} \mathrm{C}_{c}$ weight $\left(\mathrm{W}_{\mathrm{i}}\right)$.

$$
\text { TREE TREE }
$$

\% COVER DBH SPECIES HEIGHT \% COVER

\begin{tabular}{|c|c|c|c|c|c|c|c|c|c|c|c|c|c|c|c|c|c|c|c|c|}
\hline MODEL & NSTAN & BLACKBER & INDE & & INDEX & FORB & $\mathrm{CA}$ & $\mathrm{CC}$ & PC & $\mathrm{RC}$ & SC & SL & SR & LOG(L) & AlC & K & $\mathrm{AlC}_{\mathrm{c}}$ & $\Delta_{\mathrm{i}} \mathrm{AlCC}$ & L & $w_{i}$ \\
\hline 29 & 0.031 & 1.136 & $\mathrm{NA}$ & $\overline{N A}$ & 0.058 & 0.408 & NA & NA & $\overline{N A}$ & $\mathrm{NA}$ & $\overline{N A}$ & $\overline{N A}$ & $\overline{N A}$ & -97.785 & 205.569 & 5 & 206.236 & 25.756 & 0.000 & 0.000 \\
\hline 7 & 0.403 & 1.246 & 0.005 & NA & NA & NA & NA & NA & NA & NA & NA & NA & NA & -98.899 & 205.799 & 4 & 206.238 & 25.758 & 0.000 & 0.000 \\
\hline 48 & -0.008 & 1.156 & NA & 0.074 & 0.038 & 0.331 & NA & NA & NA & NA & NA & NA & NA & -96.673 & 205.346 & 6 & 206.290 & 25.810 & 0.000 & 0.000 \\
\hline 45 & -0.039 & 1.066 & 0.003 & NA & 0.045 & 0.356 & NA & NA & NA & NA & NA & NA & NA & -97.029 & 206.058 & 6 & 207.002 & 26.522 & 0.000 & 0.000 \\
\hline 24 & 0.372 & 1.093 & 0.005 & NA & NA & 0.353 & NA & NA & NA & NA & NA & NA & NA & -98.281 & 206.562 & 5 & 207.229 & 26.749 & 0.000 & 0.000 \\
\hline 57 & -0.067 & 1.092 & 0.003 & 0.069 & 0.028 & 0.292 & NA & NA & NA & NA & NA & NA & NA & -96.082 & 206.164 & 7 & 207.437 & 26.957 & 0.000 & 0.000 \\
\hline 1 & 0.784 & 1.441 & NA & NA & NA & NA & NA & NA & NA & NA & NA & NA & NA & -101.138 & 208.276 & 3 & 208.537 & 28.057 & 0.000 & 0.000 \\
\hline 10 & 0.709 & 1.231 & NA & NA & NA & 0.442 & NA & NA & NA & NA & NA & NA & NA & -100.191 & 208.382 & 4 & 208.822 & 28.342 & 0.000 & 0.000 \\
\hline 33 & 0.242 & NA & 0.005 & 0.084 & NA & 0.548 & NA & NA & NA & NA & NA & NA & NA & -99.990 & 209.980 & 5 & 210.647 & 30.167 & 0.000 & 0.000 \\
\hline 35 & 0.024 & NA & 0.004 & NA & 0.048 & 0.616 & NA & NA & NA & NA & NA & NA & NA & -100.195 & 210.389 & 5 & 211.056 & 30.576 & 0.000 & 0.000 \\
\hline 19 & 0.121 & NA & NA & NA & 0.065 & 0.706 & NA & NA & NA & NA & NA & NA & NA & -101.380 & 210.760 & 4 & 211.199 & 30.719 & 0.000 & 0.000 \\
\hline 14 & 0.463 & NA & 0.006 & NA & NA & 0.620 & NA & NA & NA & NA & NA & NA & NA & -101.526 & 211.052 & 4 & 211.492 & 31.012 & 0.000 & 0.000 \\
\hline 12 & 0.288 & NA & 0.005 & 0.095 & NA & NA & NA & NA & NA & NA & NA & NA & NA & -101.556 & 211.112 & 4 & 211.551 & 31.071 & 0.000 & 0.000 \\
\hline 38 & 0.085 & NA & NA & 0.070 & 0.047 & 0.639 & NA & NA & NA & NA & NA & NA & NA & -100.470 & 210.941 & 5 & 211.607 & 31.127 & 0.000 & 0.000 \\
\hline 17 & 0.506 & NA & NA & 0.107 & NA & 0.642 & NA & NA & NA & NA & NA & NA & NA & -101.661 & 211.322 & 4 & 211.762 & 31.282 & 0.000 & 0.000 \\
\hline 52 & -0.001 & NA & 0.004 & 0.062 & 0.032 & 0.564 & NA & NA & NA & NA & NA & NA & NA & -99.460 & 210.920 & 6 & 211.864 & 31.384 & 0.000 & 0.000 \\
\hline 13 & 0.106 & NA & 0.005 & NA & 0.048 & NA & NA & NA & NA & NA & NA & NA & NA & -102.193 & 212.387 & 4 & 212.826 & 32.346 & 0.000 & 0.000 \\
\hline 32 & 0.068 & NA & 0.005 & 0.076 & 0.030 & NA & NA & NA & NA & NA & NA & NA & NA & -101.130 & 212.259 & 5 & 212.926 & 32.446 & 0.000 & 0.000 \\
\hline 2 & 0.550 & NA & 0.007 & NA & NA & NA & NA & NA & NA & NA & NA & NA & NA & -103.494 & 212.988 & 3 & 213.249 & 32.769 & 0.000 & 0.000 \\
\hline 16 & 0.187 & NA & NA & 0.088 & 0.047 & NA & NA & NA & NA & NA & NA & NA & NA & -102.628 & 213.257 & 4 & 213.696 & 33.216 & 0.000 & 0.000 \\
\hline 3 & 0.612 & NA & NA & 0.125 & NA & NA & NA & NA & NA & NA & NA & NA & NA & -103.785 & 213.570 & 3 & 213.830 & 33.350 & 0.000 & 0.000 \\
\hline 4 & 0.247 & NA & NA & NA & 0.071 & NA & NA & NA & NA & NA & NA & NA & NA & -104.021 & 214.042 & 3 & 214.303 & 33.823 & 0.000 & 0.000 \\
\hline 5 & 0.900 & NA & NA & NA & NA & 0.774 & NA & NA & NA & NA & NA & NA & NA & -104.226 & 214.452 & 3 & 214.713 & 34.233 & 0.000 & 0.000 \\
\hline 11 & 1.205 & 0.767 & NA & NA & NA & NA & -0.113 & -0.715 & 0.297 & -0.677 & 0.199 & 0.075 & -0.755 & -78.606 & 177.211 & 3 & 401.029 & 220.549 & 0.000 & 0.000 \\
\hline
\end{tabular}


TABLE E8. Summary of all 63 models tested for Wilson's Warbler, including model terms, number of parameters (K), log likelihood value, AIC and AICc scores, change in AICc score ( AICc) between models, likelihood value (L) and AICc weight (Wi).

$\%$ COVER \% COVER \% COVER \% COVER \% COVER

\begin{tabular}{|c|c|c|c|c|c|c|c|c|c|c|c|c|c|c|c|c|c|c|c|c|}
\hline MODE & ISTAN & GWOOD & $N$ & SHRUB & CANOPY & BAY & CA & $\mathrm{CC}$ & PC & $\mathrm{RC}$ & SC & SL & SR & $\operatorname{LOG}(\mathrm{L})$ & AIC & $\mathrm{K}$ & $\mathrm{AlC}_{\mathrm{c}}$ & $\Delta_{\mathrm{i}} \mathrm{AlCC}$ & $\mathrm{L}$ & $W_{i}$ \\
\hline 29 & 1.817 & 7.983 & NA & NA & 2.658 & -9.584 & NA & NA & NA & NA & NA & NA & NA & -191.590 & 393.181 & 5 & 393.848 & 0.000 & 1.000 & 0.155 \\
\hline 48 & 1.174 & 6.738 & NA & 1.220 & 2.656 & -8.925 & NA & NA & NA & NA & NA & NA & NA & -190.510 & 393.020 & 6 & 393.964 & 0.116 & 0.944 & 0.146 \\
\hline 30 & 1.194 & 5.904 & NA & NA & 2.113 & NA & -0.669 & 2.692 & 0.925 & -0.647 & -0.028 & 1.379 & 0.454 & -185.084 & 392.167 & 11 & 395.310 & 1.462 & 0.481 & 0.074 \\
\hline 45 & 1.693 & 7.844 & 0.677 & NA & 2.431 & -8.591 & NA & NA & NA & NA & NA & NA & NA & -191.436 & 394.872 & 6 & 395.816 & 1.968 & 0.374 & 0.058 \\
\hline 51 & 1.328 & 5.904 & NA & NA & 2.113 & -5.070 & -0.149 & 2.559 & 0.849 & 0.014 & 0.594 & 1.246 & 0.370 & -184.114 & 392.228 & 12 & 395.987 & 2.139 & 0.343 & 0.053 \\
\hline 20 & 1.937 & NA & NA & NA & 2.238 & NA & -0.404 & 2.860 & 0.146 & -1.390 & -0.244 & 0.565 & -0.297 & -186.810 & 393.620 & 10 & 396.208 & 2.360 & 0.307 & 0.047 \\
\hline 57 & 1.171 & 6.740 & 0.059 & 1.205 & 2.636 & -8.846 & NA & NA & NA & NA & NA & NA & NA & -190.509 & 395.018 & 7 & 396.291 & 2.443 & 0.295 & 0.046 \\
\hline 41 & 2.070 & NA & NA & NA & 2.237 & -5.070 & 0.115 & 2.727 & 0.070 & -0.729 & 0.378 & 0.432 & -0.381 & -185.875 & 393.750 & 11 & 396.893 & 3.045 & 0.218 & 0.034 \\
\hline 11 & 2.137 & 6.356 & NA & NA & NA & NA & -0.309 & 2.981 & 1.183 & -0.458 & 0.553 & 1.641 & 0.565 & -187.316 & 394.632 & 10 & 397.220 & 3.372 & 0.185 & 0.029 \\
\hline 49 & 0.906 & 5.629 & NA & 0.440 & 2.073 & NA & -0.494 & 2.659 & 1.063 & -0.548 & 0.074 & 1.488 & 0.509 & -184.976 & 393.952 & 12 & 397.711 & 3.863 & 0.145 & 0.022 \\
\hline 46 & 1.153 & 5.798 & 0.360 & NA & 1.961 & NA & -0.584 & 2.663 & 0.904 & -0.584 & 0.083 & 1.398 & 0.445 & -185.043 & 394.087 & 12 & 397.846 & 3.998 & 0.135 & 0.021 \\
\hline 31 & 2.270 & 6.356 & NA & NA & NA & -5.075 & 0.211 & 2.848 & 1.107 & 0.203 & 1.176 & 1.508 & 0.480 & -186.389 & 394.777 & 11 & 397.920 & 4.072 & 0.131 & 0.020 \\
\hline 39 & 1.387 & NA & NA & 0.749 & 2.159 & NA & -0.128 & 2.792 & 0.443 & -1.164 & -0.052 & 0.815 & -0.144 & -186.498 & 394.996 & 11 & 398.139 & 4.291 & 0.117 & 0.018 \\
\hline 25 & 1.711 & 5.811 & 1.414 & NA & NA & NA & -0.080 & 2.785 & 1.026 & -0.265 & 0.828 & 1.642 & 0.499 & -186.543 & 395.086 & 11 & 398.229 & 4.381 & 0.112 & 0.017 \\
\hline 61 & 0.951 & 5.538 & NA & 0.585 & 2.059 & -5.308 & 0.107 & 2.509 & 1.029 & 0.176 & 0.760 & 1.384 & 0.438 & -183.922 & 393.844 & 13 & 398.283 & 4.435 & 0.109 & 0.017 \\
\hline 36 & 1.842 & NA & 0.634 & NA & 1.966 & NA & -0.264 & 2.804 & 0.133 & -1.256 & -0.040 & 0.625 & -0.288 & -186.688 & 395.376 & 11 & 398.519 & 4.671 & 0.097 & 0.015 \\
\hline 6 & 3.000 & NA & NA & NA & NA & NA & 0.000 & 3.182 & 0.357 & -1.250 & 0.357 & 0.778 & -0.240 & -189.231 & 396.462 & 9 & 398.555 & 4.707 & 0.095 & 0.015 \\
\hline 10 & 3.233 & 9.065 & NA & NA & NA & -8.406 & NA & NA & NA & NA & NA & NA & NA & -195.062 & 398.123 & 4 & 398.563 & 4.715 & 0.095 & 0.015 \\
\hline 24 & 2.604 & 8.473 & 1.733 & NA & NA & -6.123 & NA & NA & NA & NA & NA & NA & NA & -193.949 & 397.897 & 5 & 398.564 & 4.716 & 0.095 & 0.015 \\
\hline 56 & 1.425 & NA & NA & 0.893 & 2.143 & -5.432 & 0.482 & 2.636 & 0.419 & -0.412 & 0.652 & 0.720 & -0.205 & -185.427 & 394.855 & 12 & 398.614 & 4.766 & 0.092 & 0.014 \\
\hline 60 & 1.328 & 5.905 & -0.001 & NA & 2.113 & -5.071 & -0.150 & 2.559 & 0.849 & 0.014 & 0.593 & 1.246 & 0.370 & -184.114 & 394.228 & 13 & 398.667 & 4.819 & 0.090 & 0.014 \\
\hline 27 & 2.587 & 7.817 & NA & 1.222 & NA & -7.747 & NA & NA & NA & NA & NA & NA & NA & -194.053 & 398.106 & 5 & 398.773 & 4.925 & 0.085 & 0.013 \\
\hline 15 & 2.402 & NA & 1.691 & NA & NA & NA & 0.242 & 2.927 & 0.254 & -0.938 & 0.706 & 0.868 & -0.236 & -188.145 & 396.290 & 10 & 398.878 & 5.030 & 0.081 & 0.012 \\
\hline 21 & 3.133 & NA & NA & NA & NA & -5.075 & 0.519 & 3.049 & 0.281 & -0.589 & 0.980 & 0.645 & -0.324 & -188.340 & 396.681 & 10 & 399.269 & 5.421 & 0.066 & 0.010 \\
\hline 28 & 1.710 & 5.960 & NA & 0.614 & NA & NA & -0.075 & 2.928 & 1.369 & -0.326 & 0.681 & 1.786 & 0.638 & -187.115 & 396.229 & 11 & 399.372 & 5.524 & 0.063 & 0.010 \\
\hline 55 & 2.022 & NA & 0.290 & NA & 2.113 & -4.898 & 0.161 & 2.706 & 0.067 & -0.690 & 0.450 & 0.464 & -0.375 & -185.850 & 395.700 & 12 & 399.459 & 5.611 & 0.060 & 0.009 \\
\hline 47 & 1.898 & 5.905 & 1.172 & NA & NA & -4.379 & 0.329 & 2.704 & 0.987 & 0.272 & 1.318 & 1.527 & 0.438 & -185.867 & 395.733 & 12 & 399.492 & 5.644 & 0.059 & 0.009 \\
\hline 43 & 2.271 & 7.688 & 1.338 & 0.901 & NA & -6.157 & NA & NA & NA & NA & NA & NA & NA & -193.449 & 398.899 & 6 & 399.843 & 5.995 & 0.050 & 0.008 \\
\hline 50 & 1.750 & 5.866 & NA & 0.760 & NA & -5.384 & 0.532 & 2.774 & 1.332 & 0.407 & 1.372 & 1.679 & 0.566 & -186.077 & 396.155 & 12 & 399.914 & 6.066 & 0.048 & 0.007 \\
\hline 18 & 2.256 & NA & NA & 0.950 & NA & NA & 0.332 & 3.081 & 0.725 & -0.969 & 0.574 & 1.085 & -0.049 & -188.748 & 397.497 & 10 & 400.085 & 6.237 & 0.044 & 0.007 \\
\hline 38 & 0.707 & NA & NA & 2.135 & 3.170 & -7.314 & NA & NA & NA & NA & NA & NA & NA & -194.754 & 399.508 & 5 & 400.175 & 6.327 & 0.042 & 0.007 \\
\hline 37 & 2.593 & NA & 1.463 & NA & NA & -4.206 & 0.640 & 2.851 & 0.205 & -0.432 & 1.175 & 0.745 & -0.307 & -187.542 & 397.083 & 11 & 400.226 & 6.378 & 0.041 & 0.006 \\
\hline 58 & 0.911 & 5.593 & 0.215 & 0.396 & 1.986 & NA & -0.461 & 2.645 & 1.037 & -0.521 & 0.131 & 1.488 & 0.498 & -184.963 & 395.926 & 13 & 400.365 & 6.517 & 0.038 & 0.006 \\
\hline 40 & 2.288 & NA & NA & 1.094 & NA & -5.519 & 0.948 & 2.921 & 0.698 & -0.208 & 1.284 & 0.987 & -0.112 & -187.694 & 397.388 & 11 & 400.531 & 6.683 & 0.035 & 0.005 \\
\hline 53 & 1.390 & NA & 0.373 & 0.669 & 2.008 & NA & -0.075 & 2.766 & 0.404 & -1.109 & 0.048 & 0.823 & -0.156 & -186.459 & 396.918 & 12 & 400.677 & 6.829 & 0.033 & 0.005 \\
\hline 44 & 1.532 & 5.656 & 1.314 & 0.300 & NA & NA & 0.018 & 2.773 & 1.128 & -0.215 & 0.871 & 1.713 & 0.540 & -186.498 & 396.997 & 12 & 400.756 & 6.908 & 0.032 & 0.005 \\
\hline 7 & 1.945 & 7.188 & 3.064 & NA & NA & NA & NA & NA & NA & NA & NA & NA & NA & -196.213 & 400.426 & 4 & 400.866 & 7.018 & 0.030 & 0.005 \\
\hline 63 & 0.947 & 5.580 & -0.267 & 0.645 & 2.166 & -5.491 & 0.087 & 2.522 & 1.061 & 0.167 & 0.713 & 1.380 & 0.449 & -183.902 & 395.804 & 14 & 400.989 & 7.141 & 0.028 & 0.004 \\
\hline 34 & 2.024 & NA & 1.485 & 0.575 & NA & NA & 0.414 & 2.897 & 0.489 & -0.806 & 0.795 & 1.043 & -0.121 & -187.981 & 397.962 & 11 & 401.105 & 7.257 & 0.027 & 0.004 \\
\hline 62 & 1.425 & NA & -0.112 & 0.919 & 2.189 & -5.509 & 0.474 & 2.642 & 0.430 & -0.418 & 0.632 & 0.716 & -0.203 & -185.424 & 396.848 & 13 & 401.287 & 7.439 & 0.024 & 0.004 \\
\hline
\end{tabular}


TABLE E8 continued. Summary of all 63 models tested for Wilson's Warbler, including model terms, number of parameters $(K)$, log likelihood value, $\mathrm{AIC}$ and $\mathrm{AIC}_{c}$ scores, change in $\mathrm{AIC}_{c}$ score $\left(\mathrm{AIC}_{c}\right)$ between models, likelihood value $(\mathrm{L})$ and $\mathrm{AIC}_{c}$ weight $\left(\mathrm{W}_{\mathrm{i}}\right)$.

\begin{tabular}{|c|c|c|c|c|c|c|c|c|c|c|c|c|c|c|c|c|c|c|c|c|}
\hline MODEL & CONSTAN & $\begin{array}{c}\text { \% COVER } \\
\text { DOGWOOD }\end{array}$ & $\begin{array}{l}\% \text { COVER } \\
\text { WILLOW }\end{array}$ & $\begin{array}{l}\% \text { COVEF } \\
\text { SHRUB }\end{array}$ & $\begin{array}{l}\% \text { COVER } \\
\text { CANOPY }\end{array}$ & $\begin{array}{l}\text { COVER } \\
\text { BAY }\end{array}$ & CA & CC & PC & $\mathrm{RC}$ & SC & SL & SR & LOG(L) & AIC & $\mathrm{K}$ & $\mathrm{AlC}_{\mathrm{c}}$ & $\Delta_{\mathrm{i}} \mathrm{AlCc}$ & L & $W_{i}$ \\
\hline 23 & 1.315 & 6.573 & 2.786 & NA & 1.302 & $\mathrm{NA}$ & NA & NA & $\mathrm{NA}$ & NA & NA & $\mathrm{NA}$ & $\mathrm{NA}$ & -195.434 & 400.867 & 5 & 401.534 & 7.686 & 0.021 & 0.003 \\
\hline 59 & 1.611 & 5.650 & 0.986 & 0.505 & NA & -4.694 & 0.524 & 2.678 & 1.156 & 0.397 & 1.426 & 1.638 & 0.501 & -185.741 & 397.481 & 13 & 401.920 & 8.072 & 0.018 & 0.003 \\
\hline 22 & 1.618 & 6.416 & 2.687 & 0.877 & NA & NA & NA & NA & NA & NA & NA & NA & NA & -195.761 & 401.523 & 5 & 402.190 & 8.342 & 0.015 & 0.002 \\
\hline 54 & 2.102 & NA & 1.157 & 0.781 & NA & -4.705 & 0.921 & 2.801 & 0.518 & -0.193 & 1.352 & 0.968 & -0.159 & -187.243 & 398.486 & 12 & 402.245 & 8.397 & 0.015 & 0.002 \\
\hline 52 & 0.709 & NA & -0.028 & 2.141 & 3.179 & -7.351 & NA & NA & NA & NA & NA & NA & NA & -194.754 & 401.508 & 6 & 402.452 & 8.604 & 0.014 & 0.002 \\
\hline 42 & 0.855 & 5.589 & 2.307 & 1.039 & 1.450 & NA & NA & NA & NA & NA & NA & NA & NA & -194.799 & 401.597 & 6 & 402.541 & 8.693 & 0.013 & 0.002 \\
\hline 26 & 0.889 & 4.841 & NA & 1.789 & 1.996 & NA & NA & NA & NA & NA & NA & NA & NA & -196.974 & 403.947 & 5 & 404.614 & 10.766 & 0.005 & 0.001 \\
\hline 19 & 1.839 & NA & NA & NA & 3.366 & -8.047 & NA & NA & NA & NA & NA & NA & NA & -198.186 & 404.372 & 4 & 404.812 & 10.964 & 0.004 & 0.001 \\
\hline 32 & 0.506 & NA & 1.908 & 1.862 & 2.085 & NA & NA & NA & NA & NA & NA & NA & NA & -197.590 & 405.179 & 5 & 405.846 & 11.998 & 0.002 & 0.000 \\
\hline 8 & 2.016 & 5.874 & NA & 1.733 & NA & NA & NA & NA & NA & NA & NA & NA & NA & -198.815 & 405.630 & 4 & 406.070 & 12.222 & 0.002 & 0.000 \\
\hline 35 & 1.618 & NA & 1.199 & NA & 2.941 & -6.336 & NA & NA & NA & NA & NA & NA & NA & -197.757 & 405.513 & 5 & 406.180 & 12.332 & 0.002 & 0.000 \\
\hline 16 & 0.574 & NA & NA & 2.404 & 2.475 & NA & NA & NA & NA & NA & NA & NA & NA & -199.038 & 406.076 & 4 & 406.516 & 12.668 & 0.002 & 0.000 \\
\hline 9 & 1.834 & 6.520 & NA & NA & 1.925 & NA & NA & NA & NA & NA & NA & NA & NA & -199.057 & 406.114 & 4 & 406.554 & 12.706 & 0.002 & 0.000 \\
\hline 17 & 2.355 & NA & NA & 2.318 & NA & -5.545 & NA & NA & NA & NA & NA & NA & NA & -199.461 & 406.923 & 4 & 407.363 & 13.515 & 0.001 & 0.000 \\
\hline 12 & 1.599 & NA & 2.401 & 1.801 & NA & NA & NA & NA & NA & NA & NA & NA & NA & -199.575 & 407.149 & 4 & 407.589 & 13.741 & 0.001 & 0.000 \\
\hline 1 & 2.894 & 7.466 & NA & NA & NA & NA & NA & NA & NA & NA & NA & NA & NA & -200.701 & 407.403 & 3 & 407.664 & 13.816 & 0.001 & 0.000 \\
\hline 13 & 1.336 & NA & 2.758 & NA & 2.008 & NA & NA & NA & NA & NA & NA & NA & NA & -199.789 & 407.577 & 4 & 408.017 & 14.169 & 0.001 & 0.000 \\
\hline 33 & 1.995 & NA & 1.545 & 1.927 & NA & -3.751 & NA & NA & NA & NA & NA & NA & NA & -198.740 & 407.480 & 5 & 408.147 & 14.299 & 0.001 & 0.000 \\
\hline 2 & 2.364 & NA & 3.206 & NA & NA & NA & NA & NA & NA & NA & NA & NA & NA & -201.554 & 409.109 & 3 & 409.370 & 15.522 & 0.000 & 0.000 \\
\hline 3 & 1.960 & NA & NA & 2.502 & NA & NA & NA & NA & NA & NA & NA & NA & NA & -201.866 & 409.731 & 3 & 409.992 & 16.144 & 0.000 & 0.000 \\
\hline 14 & 2.732 & NA & 2.551 & NA & NA & -3.074 & NA & NA & NA & NA & NA & NA & NA & -201.012 & 410.023 & 4 & 410.463 & 16.615 & 0.000 & 0.000 \\
\hline 4 & 1.850 & NA & NA & NA & 2.620 & NA & NA & NA & NA & NA & NA & NA & NA & -203.046 & 412.091 & 3 & 412.352 & 18.504 & 0.000 & 0.000 \\
\hline 5 & 3.703 & NA & NA & NA & NA & -6.226 & NA & NA & NA & NA & NA & NA & NA & -203.141 & 412.282 & 3 & 412.543 & 18.695 & 0.000 & 0.000 \\
\hline
\end{tabular}

